\title{
Studies on the influence of cancer and hormonal cancer treatment on haemostatic parameters
}

Citation for published version (APA):

van Deijk, W. A. (1986). Studies on the influence of cancer and hormonal cancer treatment on haemostatic parameters. [Doctoral Thesis, Maastricht University]. Rijksuniversiteit Limburg. https://doi.org/10.26481/dis.19860627wd

Document status and date:

Published: 01/01/1986

DOI:

$10.26481 / d i s .19860627 w d$

Document Version:

Publisher's PDF, also known as Version of record

\section{Please check the document version of this publication:}

- A submitted manuscript is the version of the article upon submission and before peer-review. There can be important differences between the submitted version and the official published version of record.

People interested in the research are advised to contact the author for the final version of the publication, or visit the DOI to the publisher's website.

- The final author version and the galley proof are versions of the publication after peer review.

- The final published version features the final layout of the paper including the volume, issue and page numbers.

Link to publication

\footnotetext{
General rights rights.

- You may freely distribute the URL identifying the publication in the public portal. please follow below link for the End User Agreement:

www.umlib.nl/taverne-license

Take down policy

If you believe that this document breaches copyright please contact us at:

repository@maastrichtuniversity.nl

providing details and we will investigate your claim.
}

Copyright and moral rights for the publications made accessible in the public portal are retained by the authors and/or other copyright owners and it is a condition of accessing publications that users recognise and abide by the legal requirements associated with these

- Users may download and print one copy of any publication from the public portal for the purpose of private study or research.

- You may not further distribute the material or use it for any profit-making activity or commercial gain

If the publication is distributed under the terms of Article $25 \mathrm{fa}$ of the Dutch Copyright Act, indicated by the "Taverne" license above, 
Studies on the influence of cancer A N D hormonal cancer treatment oN haemostatic parameters 
- Studies on the influence of cancer A N D hormonal cancer treatment on haemostatic parameters

- Proefschrift

ter verkrijging van de graad van doctor in de geneeskunde aan de Rijksuniversiteit Limburg te Maastricht, op gezag van de Rector Magnificus, Prof. Dr. F.I.M. Bonke, volgens het besluit van het College van Dekanen, in het openbaar te verdedigen op vrijdag 27 juni 1986, des middags om 16.00 uur door

Wijgert Anthonie van Deijk

Geboren te 's-Gravenhage in 1947 
Promotor: $\quad$ Prof. Dr. H.C. Hemker

Co-promotores: Dr.M.C.E. van Dam-Mieras

Dr. G.H. Blijham

Referenten: $\quad$ Prof. Dr. M.B. Donati

Prof. Dr. J.A. Flendrig

Prof. Dr. G. Kootstra 
To Emmie, Marnix, Gerben

To my mother

In memory of my father 



\section{Contents:}

Chapter I

9 Blood coagulation in cancer

9 I.1 Introduction

9 1.2 Histology

10 I.3 Incidence of thromboembolic disease in cancer patients

11 1.4 Laboratory parameters

13 I.5 Pathophysiology

221.6 Clinical importance of blood coagulation in cancer

Chapter II

31 Outline of investigations

Chapter III

33 Evaluation of a coagulation assay determining the activity state of factor VII in plasma

Chapter IV

49 The activity state of factor VII in plasma. Two pathways for the cold-promoted activation of factor VII

Chapter V

67 Blood coagulation parameters in cancer patients, with emphasis on factor VIla and factor $\mathrm{Xa}$

Chapter VI

83 The influence of aminoglutethimide on plasma levels of medroxyprogesterone acetate: its relation with serum cortisol

Chapter VII

95 Blood coagulation enzyme profiles before and during treatment of advanced breast cancer with high-dose medroxyprogesterone acetate and aminoglutethimide

107 Summary and conclusions 
111 Samenvatting en conclusies

115 Appendix: Short outline of normal blood coagulation

118 Dankwoord

119 Curriculum Vitae 


\section{Blood coagulation in cancer}

\section{I.1. Introduction}

The relation between blood coagulation and tumor growth at the site of the primary tumor and during the development of metastases has received increasing attention in the recent literature. Trousseau first recognized this relationship in 1865 reporting a higher incidence of venous thrombosis in patients with gastric carcinoma (1). Since then, histologic evidence convincingly showed the association between tumor cells and blood coagulation products and its clinical importance was established.

Pathogenetic mechanisms are still unresolved in spite of an expanding literature implicating a role for tumor cells, platelets and cells of the phagocytic system. Based on the intimate relationship between tumor cell growth and blood coagulation pharmaceutical interventions have been proposed.

In the following the items mentioned above will be discussed in more detail in order to explain the aims of our study, outlined in Chapter II.

For a short outline of normal blood coagulation the reader is referred to the appendix in this thesis.

\section{I.2. Histology}

Thrombus formation around human tumors was reported first by Billroth in 1878 in autopsy observations (2). These findings were later confirmed by several other authors using histologic sections and light microscopy $(3,4)$. It was recognized that if tumor cells could be detected in the blood circulation, they were often associated with thrombi, looked viable and were proliferating $(5,6)$. Also with other techniques, such as histochemistry, and in studies using radioisotopes and electron microscopy, accumulation of fibrin in the direct environment of tumor cells could be shown $(7,8)$. Chew et al showed that in an animal model (Walker 256 mammary adenocarcinoma in rats), intravenous injection of tumor cells led to the formation of small amounts of fibrin in the lung after 30 seconds; the amount increased rapidly, peaked at 1 hour and disappeared in 9 hours (9). Large deposits of fibrin were also found after the injection of tumor cells into the peritoneal cavity. The 
appearance of fibrin deposition was preceeded by the appearance of peritoneal effusion dominated by aggregates of macrophages and lymphocytes (10). Also deposition of platelet thrombi in the proximity of growing tumors has been observed $(11,12)$.

In spite of this strong histologic evidence for the interaction between tumors and the components of the haemostatic system (coagulation factors, platelets, monocytes), the precise sequence of events leading to fibrin formation around tumor cells remains largely unclear.

\subsection{Incidence of thromboembolic disease in cancer patients}

Thromboembolic disease in relation with solid tumors has become a well-known phenomenon since its first description by Trousseau (1). It can manifest itself clinically in several ways (13) varying from arterial and venous thrombosis $(14,15,16)$, migratory thrombophlebitis $(17,18)$, nonbacterial thrombotic endocarditis (19, 20) and pulmonary embolism $(21,22)$ to secondary bleeding (23). Particularly migratory thrombophlebitis, thrombosis in unusual sites (such as upper extremities) and resistance to anticoagulants with breakthrough thrombosis are suggestive features of an association with neoplastic disease $(15,17,24)$. Arterial thromboembolism has been described in association with several types of cancer, among which carcinoma of the pancreas (14). In one study its incidence was in fact higher $(17 \%)$ than that of venous thrombosis $(13 \%)(25)$. Nonbacterial thrombotic endocarditis is important because of a striking incidence of systemic emboli. Embolic infarcts have primarily been found in the brain, coronary arteries, kidney, muscle and spleen $(19,26)$. A bleeding tendency, isolated or in combination with thrombosis, has been reported in association with many types of tumors, its incidence varying from 6 to $12 \%$. It is especially common in patients with carcinoma of the prostate. In contrast with the thrombotic events bleeding is usually associated with the occurrence of wide-spread malignant disease (27).

The overall incidence of thromboembolic disease in patients with cancer has been reported to vary between $1 \%$ and $11 \%(27,28)$. In post mortem studies these figures are higher, varying from $20 \%$ to $50 \%(29,30)$.

Virtually every tumor type has been reported to be associated with thromboembolic complications. Although it is well-known that pancreatic carcinoma has been associated with the greatest risk of thromboembolic disease (in up to $57 \%$ of the patients) $(13,31)$ the number of patients suffering from this complication is higher in carcinoma of the lung, because of the greater occurrence of that tumor. If one compiles two large studies, comprising a total of 
541 cases of thromboembolic disease associated with cancer, it is revealed that this complication is most often associated with lung cancer $(25 \%)(13,31)$.

Certain circumstances increase the risk of thromboembolic disease in cancer patients. A prospective study in postsurgical patients with and without cancer revealed an increased tendency to deep vein thrombosis in cancer patients (32). This was confirmed by Pineo et al, who reported that 10 out of 30 patients with cancer developed deep vein thrombosis following thoraco-abdominal surgery, as opposed to only 14 out of 134 control subjects undergoing similar procedures for nonmalignant disease $(p<0.005)(33)$. Medical treatment of the tumor may also induce thromboembolic complications. The use of certain hormonal active agents $(1-4 \%)$, $L$-asparaginase $(1-2 \%)$ and other cytostatics are known to induce or aggravate the thrombotic tendency $(34,35,36,37,38)$.

\subsection{Laboratory parameters}

Normally, the coagulation and the fibrinolytic systems are in a dynamic balance. A disturbance of this balance can llead to increased intravascular coagulation and/or increased fibrinolysis, usually indicated by increased serum fibrin(ogen) degradation products (FDP) (39). The extent of this disturbance determines the different states of intravascular coagulation and fibrinolysis (ICF) as classified by Cooper et al (40). Serious disturbance is called decompensated ICF, or acute diffuse intravascular coagulation (DIC). This situation is usually associated with a bleeding tendency. Laboratory findings include, apart from increased FDP and fibrinopeptide A (FPA) levels, decreased platelet counts, and decreased levels of fibrinogen and coagulation factors such as II, V, VII, VIII and antithrombin III $(16,41,42)$. Less severe disturbance is called compensated ICF or subacute DIC. This state is usually without clinical symptoms. Fibrinogen levels and platelet counts are normal, but other haemostatic tests show abnormally prolonged clotting times. The mildest form of disturbance is overcompensated ICF or chronic DIC. Elevated levels of FDP, thrombocytosis and hypertibrinogenemia are observed and the levels of specific coagulation factors may be elevated. This state can be associated with thromboembolic disease $(23,42,43,44)$. It is therefore not surprising that results of blood coagulation tests in patients with solid tumors - to which this review is largely restricted have differed widely $(42,45,46,47)$. On the one hand Sun et al reported at least one abnormal coagulation parameter in $98 \%$ out of 108 patients, while $69 \%$ had five or more abnormal coagulation tests. Elevated levels of FDP $(68 \%)$, hyperfibrinogenemia $(46 \%)$ and prolonged thrombin time $(69 \%)$ were observed most frequently (42). 
On the other hand in a recent abstract Drewinko et al, studying 165 patients with different advanced solid tumors, ${ }_{\text {, }}$ only rarely found marginal elevations of FPA and slightly decreased levels of AT III. These authors always found normal values for platelet counts, thrombin time, partial thromboplastin time, prothrombin time, FDP and fibrinogen. In contrast with their findings in patients with solid tumors, all leukaemia patients had two or more abnormal coagulation parameters (46).

Within these extremes, other investigators report various numbers of abnormal blood coagulation tests. Common abnormalities are increased FDP $(42,45,47,48)$, FPA $(49,50,51)$, increased fibrinogen turnover $(52,53)$, hyperfibrinogenemia $(42,43,45,54)$ but also hypofibrinogenemia (55), thrombocytosis $(30-60 \%)(42,45,55$, $56)$ and thrombocytopenia (4-11\%) (42), reduced, normal, as well as increased levels of coagulation factors such as factor $V$, factor VII, factor VIII, factor $X$, factor XIII $(42,43,46,54,55,57,58,59,60)$. Furthermore, prolonged prothrombin time $(43,45,54)$ and shortened partial thromboplastin time $(43,54)$ have been reported. AT III levels have been found to be normal or reduced $(46,47,60$, 61). In addition to the clotting factors mentioned, fibrin stabilizing factor (factor XIII) frequently has reduced activity in disseminated cancer (62).

Plasminogen levels are reported to be normal or slightly increased in solid tumors $(59,60)$.

Plasminogen activators in plasma were low in breast cancer patients (63). Some serum proteinase inhibitors, such as alpha-1-antitrypsin and $\mathrm{C}_{1}$-esterase inhibitor were found to be significantly increased, but functionally less active (64). Both low levels of plasminogen activators and low activity of serum proteinase inhibitors were proposed to contribute to hypercoagulability.

The best parameter of increased ICF reported sofar was the plasma FPA level.

FPA is one of the small peptides which is removed from fibrinogen. This removal is catalyzed by thrombin. Measurement of FPA could therefore reflect thrombin activity in vivo. With the radioimmunoassay determinations developed, increased plasma FPA levels were found in the majority of cancer patients, in spite of its short half-life (3-5 min.), apparently reflecting ongoing thrombin activity in vivo $(48,50)$. FPA levels were reported to be above the normal range in $60 \%$ of all patients; in patients with active metastatic disease at the time of presentation the level was above the normal range in as much as $95 \%$ (49).

Longitudinal studies in lung cancer patients demonstrated an upward tendency of widely varying intra-individual FPA levels that appeared to parallel the progression of clinical disease (50). 
It suggested that subclinical activation of blood coagulation may be a reflection of the interdependence of tumor growth and fibrin generation. Because warfarin treatment reduced (though did not normalize) plasma FPA levels in cancer patients a role of vitamin $K$ dependent proteases in the thrombin formation in cancer patients was suggested (50). As it has been reported that monocyte tissue factor correlated closely with simultaneous FPA levels in the patients, it was suggested that tissue factor, via activation of factor $\mathrm{V} \| \mathrm{l}$, might be responsible for in vivo thrombin generation in response, perhaps, to immune stimulation (51). However, several authors reported that heparin infusion failed to reduce plasma FPA levels to normal values (49,50). Moreover, plasma FPA levels were found to be increased during a variety of diseases, such as malignancy and inflammatory disorders, without signs of thromboembolic disease $(49,65)$. Closer examination of the FPA immunoreactive material in the assay applied by Peuscher et al showed cross-reactivity with fibrinogen and fibrinogen fragments containing the FPA moiety formed both in vivo and in vitro. With a newly developed technique using a more specific anti-fibrinopeptide-A antiserum and removing cross-reacting fibrinogen from the blood samples by polyethyleneglycol precipitation and heating, the significance of increased FPA levels in cancer patients was reevaluated.

Determinations of FPA levels in cancer patients comparing the new with the former assay, showed that in vivo activation of blood coagulation in cancer is far less frequent than is widely accepted ( $6 \%$ instead of $65 \%$ ). Moreover, the old method also measured fibrinogen fragments containing the FPA moiety formed during serine protease-mediated fibrinolysis in vitro. This observation provided an explanation for the previously observed ineffectiveness of heparin in reducing FPA levels in patients with cancer (66). The question arises whether fibrinogen breakdown in vitro could have influenced studies from other investigators as well (51). Except for fibrinogen turnover and possibly plasma FPA levels correlating with it (53), none of the tests reflects the true kinetics of blood coagulation in the patients. The activity state of blood coagulation factors could probably form a better indication of the state of intravascular coagulation, whether or not related to the extension of the malignant disease. As far as we know there are no reports on the activity state of coagulation factors in cancer patients.

\subsection{Pathophysiology}

1.5.1. Introduction

The meaning of fibrin formation around tumor cells for the behaviour of the tumor is still not clear. The discrepancies found in the 
available literature on the relation between fibrin formation and primary and metastatic tumor growth contribute to this confusion. They are caused by the heterogeneity of the experimental models used. For instance, the metastatic potency of tumor cells was studied using different types of heterogeneous tumor cells, administered in different ways in different kinds of animals. Furthermore, this process was studied in animals after intravenous infusion of tumor cells with or without simultaneous infusion of fibroblasts or dead cells, after subcutaneous injection of tumor cells and in animals with spontaneously occurring tumors.

Generally, fibrin formation around tumor cells seems to prevent the release of metastatic cells from the primary tumor but to favour metastatic tumor growth (67). For example, intravenous infusion of tumor cells in experimental animals leads to significantly more metastases after induction of a state of hypercoagulability (by stress or hyperfibrinogenemia) and hypofibrinolysis (by $\varepsilon$-aminocaproic acid). Less metastases occurred after induction of hypocoagulability (by coumarin derivatives) or hyperfibrinolysis (by plasmin or urokinase) (68). Increased potency to metastasize was also seen during simultaneous injection of tumor cells and cultured fibroblasts which contain thromboplastin as a procoagulant (69).

In an other comparable experiment, intravenous injection of viable tumor cells simultaneously with dead cells also increased the metastatic potential of the viable cells. This phenomenon, which is ascribed to fibrin formation, triggered by the thromboplastin released from the dead cells, is known as the Revesz effect (70). The importance of fibrin formation in the development and growth of metastases is also suggested by experiments in rats, which showed that decreased uptake of radioactive labeled fibrinogen in tumor tissue by anticoagulation was associated with a more favourable course of the malignant disease (71). In view of the favourable effect of fibrin formation on the metastatic tumor growth, one could hypothesize that fibrin formation around tumor cells:

1. facilitates the attachment of metastatic tumor cells to the endothelium (tumor cells which fail to adhere do not survive),

2. provides nutrients to the tumor cells,

3. serves as a structural lattice upon which tumor cells can proliferate,

4. serves as a matrix in which neovascularization takes place,

5. represents a biologic barrier against the host defense mechanism by retarding on the one hand the diffusion of tumor antigens to host lymphoid tissues and on the other hand the migration of mononuclear white blood cells to the tumor cells,

6. prevents exogenous anti-tumor substances to come in close 14 contact with tumor cells. 
However, the role of fibrin formation during the adhesion process is not elucidated. Some investigators have stressed that the tumor cells themselves adhere to the endothelium, thereby producing microinjury with concomittant platelet adhesion and fibrin deposition (72). Other authors deny that fibrin formation favours tumor growth. Dvorak et al studied two hepatocarcinoma cell lines in guinea pigs. They found that the cell line with the higher invasive capacity caused tumors with little fibrin content, whereas the tumor cell line with lower malignant capacity developed a cocoon-like fibrin gel investment, representing more than $80 \%$ of the tumor mass, which later underwent fibrous organization and even necrosis (73). The pathophysiologic basis for fibrin formation as the result of activation of blood coagulation in patients with malignancy is complex, and still not completely elucidated. There is evidence for three basic mechanisms (figure 1):

1. activation of platelets by tumor cells,

2. production of procoagulant activity (PCA) by monocytes and macrophages,

3. activation of blood coagulation by tumor cells.

1.5.2. Activation of platelets by tumor cells

In vivo studies suggest that tumor cells may cause adhesion and aggregation of platelets. Thrombi containing tumor cells and thrombocytes found in the circulation of patients with disseminated neoplastic disease point in this direction $(11,74,75)$. Most of our knowledge on platelet-tumor cell interaction however, has been derived from animal and in vitro studies. In particular, studies of Gasic et al have shed some light on the platelet-tumor cell interaction. They first reported that 15 out of 31 different murine tumors were able to aggregate murine platelets in heparinized plate rich plasma (76). As substantial variation in this platelet aggregating activity (PAA) was found, the authors speculated that the PAA might be the result of contamination of some of the tumor tissue extracts with connective tissue collagen. However, this possibility was excluded by the failure of collagenase treatment of the tumor extracts to obliterate the PAA (77). Later PAA was also detected on plasma membrane vesicles shed by transformed rat embryo cells (74). Subsequent studies also demonstrated this shedding of PAA-containing vesicles from human tumor cell lines $(78,79)$. Purification of PAA has still not been possible but data on enzyme sensitivity, cofactor requirements and cell type origin suggests the existence of at least two types of PAA $(78,79)$, to wit:

\section{a) Extractable membrane-associated PAA}

This PAA, recovered from animal tumor cell lines such as the SV40-transformed 3T3 mouse fibroblasts or PW2O renal cell 


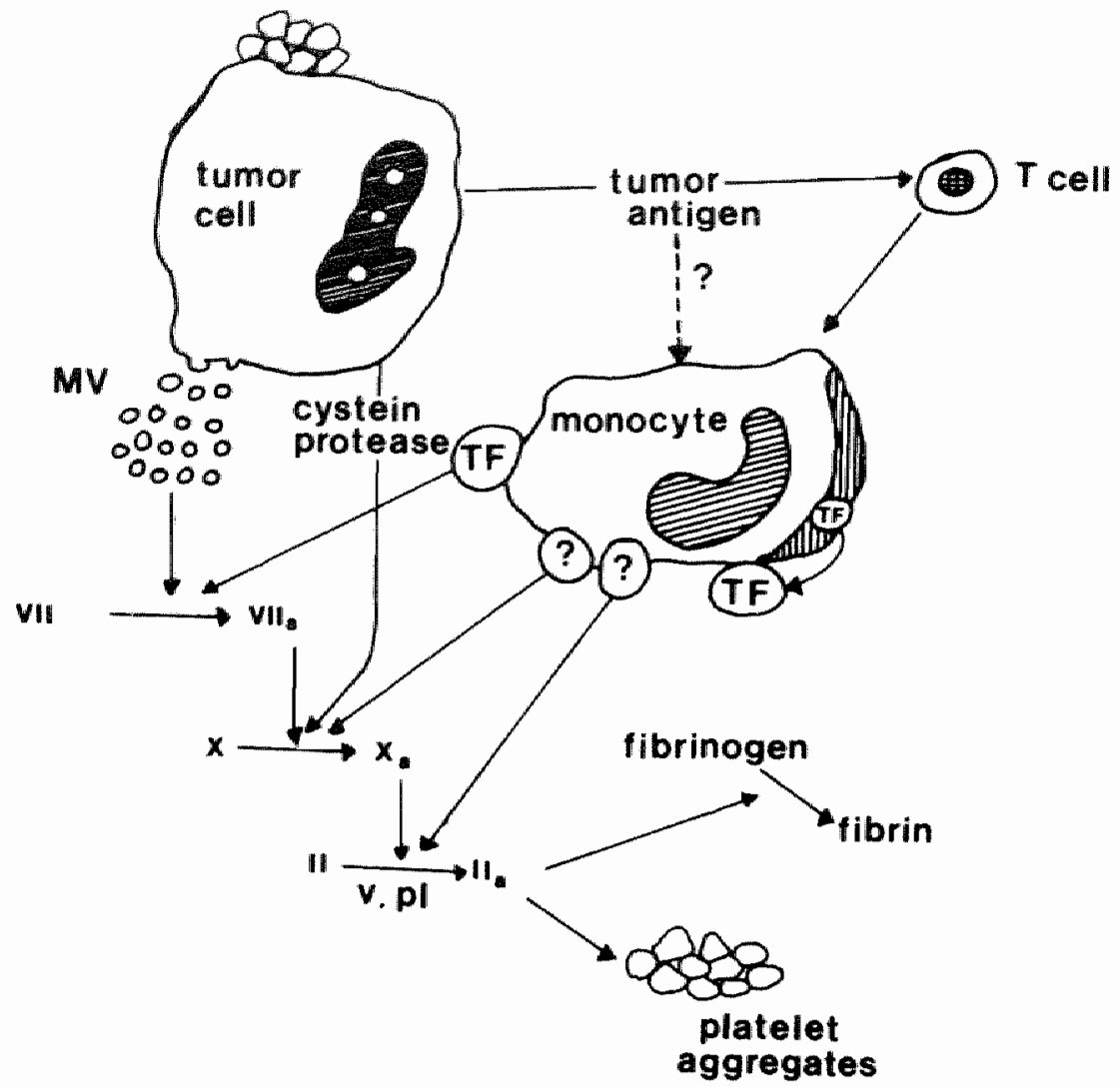

Figure 1. Scheme for the activation of blood coagulation in cancer.

Platelet (P) aggregation can occur directly by tumor cell membrane derived material or secondary to thrombin generation under the influence of tumor cells. Tumor cells and monocytes can release procoagulant activity. Monocytes may be activated to do so by tumor-associated antigens or may be regulated by $T$ cells. Monocytes may then expose tissue factor (TF) at their cell surface followed by activation of factor VII or may generate procoagulants, such as direct factor II and $X$ activating proteins. Tumor cells themselves may secrete microvesicles (MV) into the circulation or produce direct factor $X$ activating activity, identifled as a cystein protease. The net result of these interactions is thrombin activation (lla) by factor $\mathrm{Xa}$ stimulated by factor $\mathrm{V}$ and phospholipids $(\mathrm{PL}$ ) which then leads to fibrin formation. A detailed description can be found in the text. 
sarcoma of rats, appears to require a membrane sialic acid for" platelet aggregation. This cell membrane derived platelet aggregating material is trypsin-, phospholipase $\mathrm{A}_{2}$ - and neuraminidase-sensitive. It is resistant to inhibition by hirudin and dansyl-arginine- $\mathrm{N}$-(3-ethyl-1,5-pentanedyil) amide (DAPA), both "thrombin antagonists" $(80,81,82)$.

\section{b) PAA depending on the generation of thrombin by tumor cells} This type of PAA has been observed in human tumor cell lines, such as two adenocarcinomas of the colon, the U87MG glioblastoma, and melanoma and breast adenocarcinoma cell lines $(78,83,84)$. In contrast with the neuraminidase-digestible membrane sialic acid requiring $\mathrm{PAA}$, this PAA does not require this membrane component. It appears to operate via the generation of thrombin induced by the tumor cells. This type of PAA is trypsin - and neuraminidase insensitive, although still phospholipase $A_{2}$ sensitive and can be inhibited by hirudin and DAPA. It appears to be factor VII dependent, which points to a thromboplastin-like character. In the case of the carcinoma of the breast cell line, the experiments showed that the presence of factor VII is not necessary for the generation of thrombin forming activity and that the breast tumor cell line seems to activate factor $X$ directly (83). Because factor VII or factor $X$ activation are the primary events thrombin will be formed first and acts as platelet aggregating activity promoting further thrombin formation. Furthermore, thrombin formation via factor VII and factor $X$ activation will at the same time lead to fibrin formation. However, the platelet aggregating activity of thrombin does not necessarily occur to the same extent as the fibrin formation, i.e. PAA is not necessarily interrelated with PCA (83). In case of the U87MG glioblastoma cell line it was recently published that the PAA was discovered in microvesicles shed by the tumor cells (84). Both the blood coagulation and the platelet aggregation induced by these vesicles were factor VII dependent and could be inhibited by rabbit anti-bovine brain tissue factor antibodies and DAPA. These results, which were comparable to those found in HL-60 human promyelocytic leukaemia cells, strongly suggest tissue factor from microvesicles as the platelet aggregation initiating substance (84).

The importance of platelet aggregation in tumor growth was stressed by the findings of Horn et al (85). They showed that prostacyclin $\left(\mathrm{PGI}_{2}\right)$, a powerfull inhibitor of platelet aggregation, markedly reduced the number of lung metastases in mice when injected intravenously with a subline of B16 melanoma cells. This effect, which was enhanced by the simultaneous administration of theophylline, a platelet phosphodiesterase inhibitor, could only be 
found when the mice were treated with $\mathrm{PGI}_{2}$ and theophylline prior to inoculation of the tumor cells and not when the drugs were added directly to the tumor cells. Thus the beneficial effects of $\mathrm{PGl}_{2}$ seem to be due to modification of the host, rather than to an effect on the tumor cells. Furthermore, it was found that $\mathrm{PGI}_{2}$ inhibitors increased metastatic tumor formation, while thromboxane synthetase inhibitors decreased it $(85,86)$.

\subsubsection{Production of procoagulant activity ( $P C A)$ by monocytes and} macrophages

Malignant tumors contain a variable amount of macrophages amounting, in some cases, to up to $50 \%$ of the tumor material $(87,88,89,90)$. It is generally accepted that tissue macrophages originate from monocytes ultimately derived from bone marrow and supplied via the circulation. However, Stewart reported that macrophages can be actively proliferating in murine tumors, and that the speed of in vivo labeling with ${ }^{3} \mathrm{H}$-thymidine was high enough to indicate that the source of the proliferating macrophages was within the tumor itself (90). Therefore, depending on the tumor, the macrophage content is probably the sum of influx of monocytes and macrophage proliferation in situ (89).

Macrophages are multifunctional cells which can, among other things, be activated by a variety of stimuli to produce proteins able to initiate blood coagulation $(91,92,93,94,95)$. In relation to cancer, stimuli that might theoretically be considered are tumor derived antigens, immune complexes, and tumor derived or lymphocyte derived mitogens. For full expression of the procoagulant activity in response to several stimuli, T-helper cell activity $(96,97)$, lymphokines (98), and some yet unidentified serum components (99) are necessary.

As a result of their activation, macrophages can, depending on the type of the stimulus, synthesize and/or expose on their surface the following procoagulant factors:

- tissue factor-like activity $(92,93)$,

- blood coagulation factors, such as the vitamin $K$ dependent factors $(I I, V \| I, I X, X)$ and factor $V(94,95)$,

- factor $X$ activating activity (100),

- prothrombin activating activity $(101,102)$,

- activated clotting factor VII (103, 104).

The detection of these procoagulant factors stem from in vitro investigations. A role for macrophages in the activation of blood coagulation in vivo has been suggested by Edwards et al (51). In a group of patients with advanced cancer these investigators observed a direct correlation between plasma fibrinopeptide A levels and the amount of monocyte tissue factor measured in cells grown 
without exogenous stimulation. Furthermore, Lorenzet et al (105) studied rabbits bearing the V2 carcinoma and found very strong procoagulant activity in macrophages harvested from either intraperitoneally or subcutaneously growing tumors as compared with peritoneal macrophages and circulating mononuclear cells from the same animals. Moreover, endotoxin-stimulated circulating mononuclear cells from tumor bearing animals generated significantly more procoagulant activity than those from control animals. In this study the procoagulant activity was identified as tissue factor, the cell-associated protein that is capable of interaction with factor VII to activate blood coagulation. Concerning the purpose of procoagulant expression by mononuclear cells, fibrin formation around macrophages and their neighbouring tumor cells might serve as a mechanism to immobilize these cells on site. Apart from this host protecting effect of macrophages a recent in vitro study with WEHI 164 murine fibrosarcoma cells suggests that human peripheral blood monocytes might be more cytotoxic for tumor cells by the influence of proteases from the extrinsic coagulation pathway, after preincubation with lipopolysaccharides (106).

\subsubsection{Activation of blood coagulation by tumor cells}

\section{a) Introduction}

In early studies rabbit V2 carcinoma cells induced lethal thrombotic events when administered intravenously in rabbits. In vitro very short prothrombin times were obtained when these cells replaced rabbit brain thromboplastin. The relationship between in vitro and in vivo thrombogenesis proved to be dicoumarol dependent in a dose dependent way: longer prothrombin times were associated with less mortality by thrombosis. These experiments suggested the importance of factors II, VII, IX and/or X in the procoagulant activity (PCA) of the tumor cells (107). Subsequent studies have in fact suggested the presence of at least two types of PCA of cancer cells.

\section{b) Factor $X$ activators}

Gordon et al discovered a PCA in rabbit V2 carcinoma tissue that activated bovine factor $X$ directly, i.e. in the absence of factor VII and members of the intrinsic clotting pathway (108). As the factor $X$ activating activity could be inactivated by diisopropylfluorophosphate (DFP), a serine protease inhibitor, it was assumed that the tumor cell PCA was a serine protease, similar to other enzymes that can activate factor $X$. Further studies revealed that the enzyme was a cystein protease and that inhibition by DFP had been caused by an inpurity in the commercial DFP, inhibiting the cystein protease (109). This cystein protease has recently been 
characterized and is different from any other known factor $X$ activating enzyme or cystein protease (110). No such enzyme activity was found in normal cells (111). Possibly similar but yet uncharacterized, factor VII-independent, factor X-dependent PCA has been found in tissue extracts of human cancers of the breast, colon, vagina, kidney and lung $(108,111)$ and in other animal tumors such as Lewis lung carcinoma in mice, mouse Ehrlich ascites carcinoma cells and JW sarcoma cells $(112,113)$. Of importance was the observation by Curatolo et al $\mathrm{l}_{\mathrm{s}}$ that factor $\mathrm{X}$ activating activity could be established in cultures of single cell suspensions, as until then only tissue extracts were studied, in which also other cells such as macrophages, endothellal cells and connective tissue were present (113). The direct factor $X$ activating activity was later confirmed using an amidolytic assay (114). It must be mentioned that there are also many tumors which do not produce this direct factor $X$ activating activity $(113,115)$. Recently, Donati et al first described direct factor $X$ activating PCA in purified cell suspensions of a human tumor (melanoma). This PCA was not found in benign naevi (116).

\section{c) Factor VII dependent (thromboplastin-like) procoagulants}

The first observation stressing the importance of tissue factor, as a factor VII dependent procoagulant, in relation with malignant cells comes from Eiseman et al (117). These investigators observed thromboplastic activity of promyelocytic leukaemia cells, which was later proven to be identical to human brain tissue factor by the use of a specific antibody to human brain tissue factor (118).

Tissue factor is a factor VII- and factor X-dependent membrane protein without discernable serine protease activity of its own (DFP-resistant). It has been described in a variety of normal tissues, in animal tumors and in several human tumors. Apart from the promyelocytic leukaemia cells already mentioned, it is also present in human chronic myeloid and lymphoid leukaemia cells and in histiocytic lymphoma $(119,120)$. As to the solid tumors, it has been described in relation with osteogenic sarcoma (121), adenocarcinoma of the colon (78), melanoma (122) and renal cell carcinoma (123). In the experiments mentioned, there was none designed to eliminate the contamination of tumor cells with monocytes or macrophages. It is therefore still possible that a small percentage of monocyte-macrophage cells might contribute to the observed PCA. Dvorak et al, however, studied 14 tumor cell lines of guinea pig ( 3 lines), mouse ( 1 line) and human origin (10 lines) with less than $2 \%$ contaminating macrophages and lymphocytes (115). Thirteen of these 14 tumor cell lines spontaneously shed plasma membrane derived vesicles with PCA during short tissue culture. 
None of the 9 human tumor cell line-derived vesicles tested (5 teratoma, 2 EBV-transformed lymphoblastoid, 2 bladder carcinoma cell lines) expressed a direct factor $X$ activating activity, independent of factor VII. The evidence that shed human tumor vesicles in fact expressed tissue factor activity was given firstly by the observation that the serum free conditioned medium and ultracentrifuge pellets (containing the vesicles, as shown by electron microscopy), but not the ultracentrifuge supernatant, derived from the conditioned medium "cleaved bovine $3 \mathrm{H}$-factor $\mathrm{X}$ only in the presence of factor VII. Secondly, this activity was neutralized by a highly specific anti-bovine brain tissue factor antibody (suggesting the structural homology between the factor on human tumor vesicles and bovine brain tissue factor). In these experiments no soluble proteases were found that activated factor $\mathrm{X}$ directly, as described by Gordon et al (109). This may be explained by differences in techniques and tumor cell types used.

1.5.5. Cancer and fibrinolysis with emphasis on alpha-2-antiplasmin Besides with activation of blood coagulation, cancer can also be associated with increased fibrinolysis. This phenomenon can develop secondary to activation of blood coagulation, but can also occur as a primary event due to production of plasminogen activators (PA) by human as well as animal tumor cells $(63,124,125$, $126)$ or their accompanying monocytes-macrophages (127). The resulting plasmin formation may have an important role in the formation of metastases by the degradation of capillary basement membrane material, together with collagenases type IV and V (128). Indeed, some (but not all) investigators found a relationship between primary tumor growth or the formation of metastases and the production of plasminogen activators by tumors in animal models $(125,126,129)$.

Another interesting observation is the induction of PA by estradiol in humain breast cancer cells in culture. This estrogen-induced production of PA is antagonized by the anti-estrogen tamoxifen (129). Consequently, the possible correlation between the estrogen receptor (ER) content and the total amount of $P A$, and between the ER content and the relative amounts of the two different forms of PA ( $t-P A=$ tissue-type PA and $u-P A=$ urokinase-type PA), has been investigated in human breast tumor biopsies. $t$-PA was found in $3.2 \%$ of the ER-negative tumors, in $32 \%$ of the tumors with borderline levels of ER and in $52 \%$ of the ER-positive tumors $(p<0.001$ for ERnegative versus ER-positive tumors). In contrast, neither total PA nor $\mathrm{U}$-PA showed any correlation with the ER. These findings in the ERpositive tumors suggest that the occurrence of $t-P A$ reflects a functional ER, while the absence of t-PA reflects a non-functional 
ER. Future studies will test the hypothesis if the t-PA positive, ERpositive tumors will respond to hormonal therapy, while the t-PA negative, ER-positive tumors will not (130).

In summary, a continuous production of plasminogen activators as well as activation of blood coagulation in malignancy might contribute to the chronic primary or secondary fibrinolysis, respectively. In such circumstances it is interesting to measure alpha-2-antiplasmin levels which might reflect the amount of fibrinolysis occurring.

Alpha-2-antiplasmin is the physiologically most important inhibitor in controlling plasmin-induced fibrinolysis. Cross-linked to fibrin it causes almost instantaneous inhibition of plasmin (the product of cleavage of fibrin-bound plasminogen by fibrin-bound plasminogen activators), which is generated on the surface of fibrin. It may further inhibit fibrinolysis by its interference with the adsorption of plasminogen to fibrin (131). In clinical diffuse intravascular coagulation with increased plasmin generation, alpha-2-antiplasmin will form a complex with plasmin.

Depending on the severity of the intravascular coagulation alpha-2-antiplasmin concentrations can subsequently be markedly reduced, as has been observed in patients with acute promyelocytic leukaemia $(132,133,134)$.

\section{I.6 Clinical importance of blood coagulation in cancer}

The question arises whether the role of blood coagulation in cancer patients is so essential that pharmaceutical modulation of coagulation might influence the course of malignant disease. This question has first been addressed in animal models. Especially coumarin derivatives such as warfarin have been shown to reduce the occurrence of metastases, for instance in the Lewis lung carcinoma in mice $(135,136)$. In the same animal model Hilgard confirmed these findings. Moreover, inhibition of growth of the primary tumor was observed. The author showed that this anti-tumor effect depended on a continuously well-controlled state of anticoagulation. A deliberate interference with adequate anticoagulation or reduction of treatment duration to less than 11 days made the treatment ineffective (137). In an other experiment Hilgard showed, again in the mouse, that up to 24 hours after intravenous injection of Lewis lung carcinoma cells warfarin was still able to prevent the occurrence of lung metastases. So warfarin was still active in its antimetastatic effect after the arrest of tumor cells in the pulmonary capillary vessels. This effect of warfarin was present even after creating a state of hypercoagulability induced with human prothrombinase complex (137). Experiments with methylcholantreneinduced mammary carcinoma in mice showed that the 
antimetastatic effect was maximal with prolongation of coagulation tests to 2.5-3 times normal (138).

The exact mechanism of the antimetastatic effect of warfarin is still not clear. In the literature arguments can be found that hold responsible:

1. the anticoagulation effect itself (139),

2. a cytostatic effect $(140,141,142)$,

3. non-specific immune stimulation (143).

In human cancer several uncontrolled non-randomized trials of warfarin treatment have been performed with promising results (144, $145,146,147)$. The first randomized study which showed a beneficial effect of anticoagulation on survival was done in small cell lung carcinoma, both in patients with limited as well as extensive disease. Adding warfarin to chemotherapy led to a significantly better survival ( 50 versus 26 weeks, $p=0.026$ ) than treatment with chemotherapy alone (148). Other authors could not confirm these findings, possibly because these studies only included patients with extensive disease $(149,150)$. A Veteran Administration Study in colon, prostate, head and neck and non-small cell lung carcinoma (NSCLC) did not show a significant difference in survival between patients treated with warfarin versus those without warfarin. Although warfarin seemed to improve survival in limited disease NSCLC, these results did not reach significance, possibly because a low number of patients of this type was included (151). Remarkably, the extent of anticoagulation by warfarin in the patients was not mentioned.

The question arises whether the fibrin formation around tumor cells might act disadvantageously on the antineoplastic potential of coumarin derivatives, based on the three mechanisms just mentioned. The anticoagulation effect would only be able to prevent further fibrin formation, but the existing fibrin prevents the coumarin derivative or cells participating in the immune system such as the macrophages or hormonal and cytostatic drugs to come to close contact with the tumor cells. To solve this hypothetical problem one could favour the use of plasminogen activators or fibrinolytic agents which could be administered systemically and would only act locally to cause fibrinolysis after binding to fibrin. Administration of these drugs should then be followed by the administration of the coumarin derivative to prevent renewed fibrin formation. Agents such as tissue plasminogen activator ( $t$-PA) and plasmin acylated at its active site serine have been developed which exert their fibrinolytic action locally after binding to fibrin $(152,153,154)$. They are presently under clinical investigation in relation with other thrombotic disorders and their role is still uncertain (154). 


\section{References}

1. Trousseau A. Phlegmasia aba dolens. Clinique medicale de l'Hotel- Dieu de Paris, London. New Sydenham Society 3: 695-727, 1868

2. Billiroth T. Lectures on surgical pathology and therapeutics, translated from the Bth ed. London. New Sydenham Society, 1878 .

3. Irvasaki $T$. Histological and experimental observations on the destruction af tumor cells in the blood vessels. J. Path. Bact. 20: 85-104, 1915.

4. Saphir O. The late of carcinoma emboli in the lung. Am. \& Pathol 23:245-253, 1947.

5. Morgan A.D. The pathology of subacute cor pulmonale in diffuse carcinomatosis of the lungs. J. Path. Bact. 61: 75-84, 1949.

6. Winterbauer R.H., Elfenbein I.B., Ball W.C. Jr. Incidence and clinicall significance of tumor embolization to the lungls. Am. J. Med. 45:271-290, 1968 .

7. Spar I.L., Bale W.F., Marrack D., Dewey W.C., McCardie Fi.J., Harper P.U. 131 -labeled antibodies to human fibrinogen. Diagnostic studies and therapeutic trials. Cancer $20: 865 \times 870,1967$.

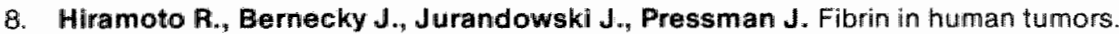
Cancer Pies: $30: 592-593,1970$.

9. Chew E., Wallace A.C. Demonstration of fibrin in early stages of experimental metastases. Cancer Res. 36:1904-1909, 1976.

10. Dvorak A.M., Connell A.B., Proppe K., Dvorak H.F. Immunologic rejection of mammary adenocarcinoma (TA-3-St) in C57 BL/6 mice: participation of neutrophils and activated macrophages with fibrin formation. U. Immunol. 120: 1240-1248, 1978.

11. Warren B.A. Platelet-tumor cell interactions. Morphological Studies. In: Platelets; $A$ multidisciplinary approach. de Gaetano G., Garattini S. (eds.)

Raven Press. New York. 427-446, 1978.

12. Marcum J.M., McGill M., Bastida E., Ordinas A., Jamieson G.A. The interaction of platelets, tumor cells and vascular subendothelium.

1. Lab. Clin. Med. 96:1046-1054, 1980.

13. Sack G.H. Jr., Levin J., Bell W. Trousseau's syndrome and other manifestations of chronic disseminated coagulopathy in patients with neoplasms: clinical, pathologic and therapeutic features. Medicine $56: 1-37,1977$.

14. Al-Mondhiry H. Disseminated intravascular coagulation. Experience in a major cancer center. Thromb. Diath. Haemorrh. 34:181-193,1975.

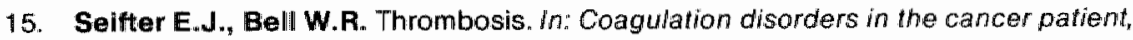
Futura Publishing Company, New York. 121-145, 1984.

16. Bell W.R., Starksen N.F., Tong S., Porterfield J.K. Trousseau's syndrome: Devastating coagulopathy in the absence of heparin. Am. J. Med. 79: 423-430, 1985.

17. Durham R.H. Thrombophlebitis migrans and viscerall carcinoma. Arch Int Med. 96: 380-386, 1955.

18. Nusbacher J. Migratory wenous thrombosis and cancer. N.Y. State J. Med. 64: 21662173,1964 .

19. Rosen P., Armstrong D. Nonbacterial thrombotic endocarditis in patients with mallignant neoplastic disease. Am. J. Med. 54: 23-29, 1973.

20. MacDonald R.A., Robbins S.L. The significance of nonbacteriall thrombotic endocarditis. Autopsy and clinical study of 78 patients.

Ann. Int Mod 46: 255-273, 1957.

21. Nusbacher J. Migratory venous thrombosis and cancer: Mechanisms and clinical manifestations. Progress in Cinical Cancer 3: 151-156, 1967.

22. Gore J.M. Appelbaum J.S., Greene H.L., Dexter L. Dalen J.E. Occult cancer in patients with acute pulmonary embolism. Amn. Int. Med. 99: 556-560, 1982.

23. Bick $R_{n}$ L. Alterations of hemostasis associated with malignancy: etiology, pathophysiology, diagnasis and management. Sem. Thromb. Haemost. 5: 1-26, 1978 .

24. Editorial. Haemostatic abnormalities and mallignant disease Lancet $i: 303-304,1986$. 
25. Thompson C.M. Rodgers R.L. Analysis of the autopsy records of 157 cases of carcinoma of the parncreas with particular reference to the incidence of thromboembolism. Am. J. Med. Sci. 223:469-475, 1952 .

26. Koolker J.C., MacLean J.M., Sunai S.M. Curebral embolism, marantic endocarditis and cancer. Arch. Neurol. 33:260-264, 1976.

27. Donati M.B., Poggi A., Semeraro N. Coagulation and malignancy. In: Recent advances in blood coagulation, wol. 3. Ed: Poller L, Churchill Livingstone, Edinburgh. 227-259, 1981.

28. Hoerr S.O., Harper J.R. On peripheral thrombophlebitis, its cccurrence as a presenting symptom of malignant disease of pancreas, biliary tract, or duodenum. J.A.M.A. 164: 2033-2044, 1957 .

29. Ambrus J.L., Ambrus C.M., Mink L.B., Pickren JI.W. Causes of death in cancer patients. J. Med. 6: 61-64, 7975 .

30. Sproul E.E. Carcinoma and venous thrombosis: The frequency of association of carcinoma in the body or tail of the pancreas with multiple venous thrombosis. Am. J. Canc. 34: 566-585, 1938.

31. Ambrus J.L., Ambrus C.M., Pickren J.W., Soldes S., Bross 1. Haematologic changes and thromboembolic complications in meoplastic disease and their relationship to metastases. J. Med. 6: 433-458, 1975.

32. Kakkar V.V., Howe C.T., Nicolaides A.N., Renny J.T.G., Clarke M.B. Deep vein thrombosis of the legs. Is their a high risk group? Am. J. Surg. 120:527-530, 1970.

33. Pineo G.F., Brain M.C., Galkes A.S., Hirsch J., Hatton M.W.C., Regoeczl E. Tumors, mucus production and hypercoagulabillty. Ann. N.Y. Acad. Sci. 230:26.2-270, 1974.

34. Enck R.E., Rios C.N. Tamoxifen treatment of metastatic breast cancer and antithrombin III levels. Cancer 53: 2607-2609, 1984.

35. Kucuk D., Kwaan H.C., Gunnar W., Vazquez R.M. Thromboembollic complications associated with L-Asparaginase therapy. Cancer 55: 702-706, 1985.

36. Kasimis B.S., Spiers A.S.D. Thrombotic complications in patients with advanced prostatic cancer treated with chemotherapy. Lancet $i: 159,1979$.

37. Weiss R.B., Tormey D.C., Holland J.F., Weinberg V.E. Venous thrombosis during multimodal treatment of primary breast carcinoma. Cancer Treat. Rep. 65: 677-679, 1981.

38. Schenk H., Fereberger W. Gestagen-therapie des Mammakarzinoms, Einfluss hoher dosen auf das Gerinnungssystem. Münch. Med. Wschr. 125: 875-876, 1983.

39. Gallimore M.J., Tyler J.M., Shaw J.T.D. The origin of fibrin breakdown products and the interpretation of their appearance in the circulation.

l. Clin. Pathol 25: 185-190, 1972.

40. Cooper H.A.y Bowie E.J.W., Owen C.A. Jr. Evaluation of patients with increased fibrinolytic split products (FSP) in their serum. Mayo Clin. Proc. 49:654-657, 1974.

41. Rodriguez-Erdman F. Bleeding due to increased intravascular blood coagulation. Haemorrhagic syndromes caused by consumption of blood-clotting factors (consumption coagulopathies). New Engl. J. Med. 273: 1370-1378, 1965.

42. Sun N.C.J., McAfee W.M., Hum G.J., Weiner J M. Hemostatic abnormalities in malignancy, a prospective study of one hundred eight patients. Part 1. Coagulation studies. Am. J. Clin. Pathol. 71: 10-16, 1979.

43. Rasche $H_{2}$, Dietrich $\mathrm{M}$. Hemostatic abnormalities associated with malignant diseases. Eur. J Cancer 13: 1053-1064, 1977.

44. Rickles F.R. Edwards R.L. Activation of blood coagulation in cancer. Trousseau's syndrome revisited. Blood 62: 14-31, 1983.

45. Hagedorn A.B., Bowie E.J.W., Elveback L.R., Owen C.A. Coagulation abnormalities in patients with inoperable lung cancer. Mayo Clin. Proc. $49.649-653,1974$.

46. Drewinko B., Schmidt D., Bollinger P., Keating M., Trujillio J M. Coagulation profiles of untreated cancer patients. Proc. of Am. Soc. Chro. Oncol 4: 19, 1985.

47. Kiles M.S., Posch J.J., Giolma J.P., Rubin R.N. Haemostatic function in cancer patients. Cancer 46:831-837, 1980. 
48. Carlason 5. Fibrinogen degradation products in serum from patients with cancer. Actei Chir. Scand 139: 499-502, 1973.

49. Peuscher F.W., Cleton E.J., Armstrong L., Stoepman wan Dalen E.A., van Mourik J.A., van Aken W.C. Significance of plasma fibrinopeptide A (FPA) in patients with mallgnancy. J. Lab. Clin. Med. 96:5-14, 1980.

50. Rilckles $\mathbf{F}$. $\mathbf{R}_{*}$, Edwards R.L., Barb C., Croniund M. Abnomalities of bllood coagulation in patients whth cancer: fibrinopeptide A generation and tumon growth. Cancer $51: 301-$ $307,7983$.

51. Edwards R.L., Rickles F.R., Cronlund M. Abnormalities of blood coagulation in patients with cancer: mononuclear tissue factor generation.

J. Lab. Clin. Med. 98: 917-928, 1981.

52. Silchter S.J., Harker L.A. Hemostasis in malignancy, Anv. N.Y. Acad. Scl. 230: 252-261, 1974 .

53. Yodia $Y_{*}$ Abe T. Fibrinopeptide A (FPA) level and fibrinogen kinetics in patients with malignant disease. Thromb. Haemostas. 46: 706-709, 1981 .

54. Perlin E.; Scialla $\mathbf{S} . \mathbf{J}$. . Connor $\boldsymbol{R}$. Blood coagulation profiles ir patients with carcinoma of the lung. Milt. Med. 147: 296-298, 1982.

55. Goodnight S.H. Jr. Bleeding and intravascullar clotting in malignancy: a review. Ann. N.Y. Acad. Sici. 230: 271-288, 1974.

56. Levin $\mathrm{J} .$, Conley C.L. Thrombocytosis associated with mallignant disease. Arch. Int Med. 114:497-500, 1964.

57. Davis R.B., Theologides A., Kennedy B.J. Comparative studies of blood coagulation and platelet aggregation in patients with cancer and nonmalignant diseases. Ann. Int. Med $71: 67-80,1969$.

58. Dsterud B., Due J. Jr., Blood coagulation in patients with benign and malignant tumours belore and after surgery: speciall reference to thromboplastin generation in monocytes. Scand. J. Haematol. 32: 258-264, 1984.

59. Soong B.C.F., Miller S.P. Coagulation disorders in cancer. Ill. Fibrinolysis and inhibitors. Cancer 25:867-874, 1970.

60. Manuccil P.M., Vaglini M., Maniezzo M., Magni E., Mari D., Cascinelli N. Haemostatic alterations are unrelated to the stage of tumor in untreated malignant melanoma and breast carcinoma. Eur. J. Cancer Clin. Oncol. $21: 681-685,1985$.

61. Honegger H., Anderson N., Hewitt L.A., Tullis J.L. Antithrombin II profiles in malignancy, relationship to primary tumors and metastatic sites.

Thromb. Haemostas, 46: 500-503, 1981 .

62. Mandel E.E., Minn S.K. Factor XIII activity of platelets and plasma in health and disease. Thromb. Res. 3: 437-450, 1973.

63. Collombi M., Barlati S., Magdelenat H., Fiszer-Szafarz B. Relationship between multiple forms of plasminogen activator in human breast tumors and plasma and the presence of metastases in lymph nodes. Cancer Res. 44: 2971-2975, 1984.

64. Chawla R.K., Rausch D.d., Miller F.W., Vogler W.R., Lawson D.H. Abnormal profile of serum proteinase inhibitors in cancer patients. Cancer Res. 44:2718-2723, 1984.

65. Nossel H.L., TI M., Kaplan K.L., Spanondis K., Soland T,, Butler V.P. The generation of fibrinopeptide A in clinical blood samples. U. Clin. invest. 58: 1136-1144, 1976.

66. Leeksma O.C. Fibrinogen, fibrinopeptide A, platelets and endothellial cells. Thesis, 1985 .

67. Zacharski L.R., Henderson W.G., Rickles F.R., Forman W.B., Cornell C..ll. Jr., Forcler R.J., Harrower H.W., Johnson R.O. Rationale and experimental design for the VA cooperative study of anticoagulation (warfarin) in the treatment of cancer. Cancer 44: $732-741,1979$.

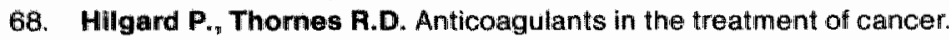
Eur. J. Cancer 12: 755-762, 1976.

69. Gasilc G.J., Gasic T.B., Murphy S. Antimetastatic effect of aspirin. Lancer it: $932-933,1972$.

Peters L.J., Hewitt H.B. The influence of fibrin formation on the transplantability of 
murine tumour cells: Implications for the mechanism of the Revesz effect.

Br. J. Cancer 29: $279-29 \%, 1974$.

71. Schaeffer J.R. Interfierence in locallization of $\mathrm{J}-131$ fibrinogen in ral tumors by anticoagulants. Am. J. Physiol. 206: $5734579,1964$.

72. Warren B.A. Cancer cell endothelial reactions: the microinjury hypothesis and localized thrombosis in the formation of micrometastases. In: Malignancy and the Hemostalic System. Donati M.B. Davidson J.F., Garattini S. (eds.).Raven Press, New York, 5-25, 1981.

73. Dvorak H.F., Dvorak A.M., Manseavi E.J., Wibeng L. Churchill W.H. Fibrin gel investment associated with line 1 and line 10 solid tumor growth, angiogenesis, and fibroplasia in guinea pigs: Role of cellular immunity, myofibroblasts, microvascular damage, andi infarction in line 1 tumor regression.

J. Natt. Cancer Inst. 62: 1459-1472, 1979.

74. Gasic G.J., Boettiger D., Catalfamo J.L., Gasic T.B., Stewart G.J. Aggregation of platellets and cell membrane vesiculation by rat cells transformed 'in vitro' by Rous sarcoma virus. Cancer Res. 38 : 2950-2955, 1978 .

75. Ambrus J.L., Ambrus C.M., Gastpar H. Studies on platelet aggregation and platelet interaction with tumor cells. In: Plafelets: A multidisciplinary approach de Gaetano $G$. Garattini S. (eds). Raven Press, New York. 467-480, 1978.

76. Gasic G..J., Gasic T.B., Galanti N., Johnson T., Murphy S. Platelet-tumaur cell interactions in mice. The role of platelets in the spread of malignant disease.

Int. J. Cancer 11: 704-718, 1973.

77. Karpatkin S., Pearlistein E. Role of platelets in tumor cell metastases. Ann. Int. Med. 95 : $636-641,1981$.

78. Pearlstein E.P., Ambrogio C., Gasic G.J., Karpatkin S. Inhibition of platelet-aggregating activity of two human adenocarcinomas of the colon and an anaplastic murine tumor with a specific thrombin inlhibitor, dansylarginine $N-(3-o t h y l-1,5$ pentanediyl) amide. Cancer Res. 41: 4533-4539, 1981.

79. Bastida E., Ordinas A., Jamleson G.A. Differing platellet aggregating effects by two cell lines: absence of role for platelet derived ADP.

Am. J. Hematol. 11: $367-378,1981$.

80. Pearlstein E, Cooper L.B., Karpatkin S. Extraction and characterization of platelet-aggiregating material from SV40 transformed mouse 3 T3 fibroblasts. J. Lab. Clin Med, 93: 332-344, 1979.

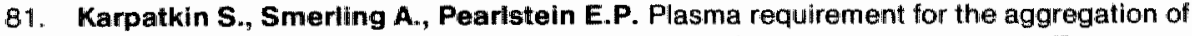
rabbit platelets by an aggregating material derived from SV40 transformed $3 T 3$ fibroblasts. J. Lab. Clin. Med. 96:994-1001, 1980.

82. Pearistein E.P., Salk P.L., Yogeeswaran G., Karpatkin S. Correlation between spontaneous metastatic potential, platelet-aggregating activity of cell extracts, and cell surface sialylation in 10 metastatic wariant derivates of a rat renal sarcoma line. Proc. Natl. Acad. Sci. USA 77: 4336-4339, 7980.

83. Al-Mondhiry $\mathrm{H}_{n}$, McGarvey $\mathrm{V}$., Leitzel $\mathrm{K}$. Interaction of human tumor cells with human piatelets and the coagulation system.

Thromb. Haemostas. (Stutigart) 50:726-730, 1983

84. Bastida E., Ordinas A., Escolar G. Jamieson G.A. Tissue factor in microvesicles shed from U87MG human glioblastoma cells induces coagulation, platelet aggregation, and thrombogenesis. Blood 64: 177-184, 1984.

85. Honn K.V., Cicone A., Skoff A. Prostacyclin: a potent antimetastatic agent. Science 212: 1270-1272, 1981.

86. Honn K.V., Dunr J.R. Nafazatrom (Bay g6575) inhibition of tumor cell lipaxygenase activity and cellular proliferation. FEBS Lett. 139:65-68, 1982 .

87. Evans $\mathbf{R}$. Effect of $X$-irradiation on host cell infiltration and growth of a murine fibrosarcoma. Br. J. Cancer 35: 557-566, 1977.

88. Evans R., Eidler D.M. Macrophage accumulation in transplanted tumors is not dependent on host immune responsiveness or presence of tumor-associated rejection antigens. J. Reticuloendothelial Soc. 30: 425-437, 1981 . 
89. Evains $R_{i}$ Macrophages and reoplasms: new insights and their implication in tumor immunobiology. Cancer Metastases Reviews 1: 227-239, 1982.

90. Stewart C.C. Local proliferation of mononuclear phagocytes in tumors.

L. Reticuloendothelial Soc. 34: 23-27, 1983.

91. Semeraro M., Lettanzio A., Montemurro P., Papanice M., de Lucia O., de Bellis G., Giordano D. Mechanisms of blood clotting activation in inflammation: the role of mononuclear phagocytes. Int. J. Tiss. Reac. $7: 313-320,1985$.

92. Edglington T.S. Recognition coupled responses of the monocyte: activation of coaglulation pathways. Nouv. Revue Fr. Hémat. 25: 1-6, 1983.

93. Osterud 8., Bogwald J., LindahI U., Seljelid R. Production of blood coagulation factor $V$ and tissue thromboplastin by macrophages in vitro.

FEBS Lett. 127: 154-156, 1981.

94. van Dam-Mileras M.C.E., Muller A.D., van Deilk W.A., Hemker H.C. Clotting factors secreted by monocytes and macrophages: analytical considerations.

Thromb. Res. 37: 9-19, 1985.

95. Muller A.D., van Dam-Mleras M.C.E., Hemker H.C. Measurement of macrophage cellular procoagulant activity. Haemostasis 15:" 108-113, 1985.

96. Edwards R.L., Rickles F.A. The role of thuman T cells (and T cell products) for monocyte tissue factor generation. I. Immunol. 125: 606-609, 1980 :

97. Schwartz B.S., Edgington T.S. Lymphocyte collaboration is required for induction of murine monocyte procoagulant activity by immune complexes. $U$. Immunol. 127: 438. 443,1981 .

98. Edwards R.L., Rickles F.R. Bobrove A.M. Mononuclear cell tissue factor; cell of origin and requirements for activation. Blood 54: 359-370, 1979.

99. Edwards R.L., Perla D. The effect of serum on monocyte tissue factor generation. Blood 64: 707-714, 1984 .

100. Shands J.W.Jr. The endotoxin-induced procoagulant of mouse exsudate macrophages: a factor $X$ activator. Blood 62: 333-340, 1983.

101. Tracy P.B., Rohrbach M.S., Mann K.C. Functional prothrombinase complex assembly on isolated monocytes and lymphocytes. J. Biol. Chem. 258: 7264-7267, 19.83.

102. Schwartz B.S., Levy G.A., Curtiss L.IK., Fair D.S., Edgington T.S. Plasma lipoprotein induction and suppression of the generation of cellular procoagulant activity in vitro.

Two procoagullant activities are produced by peripheral blood mononuclear cells.

J. Clin. Invest. 67: 1650-1658, 1981.

103. Broze G.J. Binding of humain factor VII and VIlla to monocytes.

J. Clin. Invest. 70: 526-535, 1982.

104. Fair D., Tsao B., Curtiss L, Edgington T.S. Monocytes can be induced by lipopolysaccharidle stimulated T cells to express factor VII activity.

Thromb. Haemostas. 50: 172, 1983.

105. Lorenzet R., Peri G., Locatĩ D., Allavena P., Colucci M., Semeraro N., Mantovani A., Donati M.B. Generation of procoagulant activity by mononuclear phagocytes:

a possible mechanism contributing to blood clotting activation within malignant tissues. Blood 62: $271-273,1983$.

106. Edgington T.S., Kornbluth R.S. Plasma dependence of a novel form of cellular cytotoxity. Thromb. Haemostas. 54: 121, 1985.

107. Lawrence E.A., Bowman D.E., Moore D.B., Bernstein G.ll. A thromboplastic propenty of neoplasms. Surg. Forum 3: 694-698, 1952.

108. Gordon S.G., Franks J.J., Lewis B.J. Cancer procoagulant A: a factor $X$ activating procoagulant from malignant tissue. Thromb. Res. 6: 127-137, 1975.

109. Gordon S.G. Cross B.A. A factor X-activating cysteine protease from malignant tissue. J. Clin. Invest. 67: 1665-1671, 1981.

110. Falanga A., Gordon S.G. Isolation and characterization of cancer procoagulant: a cysteine proteinase from malignant tissue. Biochemistry 24: $5558-5567.1985$.

111. Gordon S.G., Franks J.J., Lewis B.J. Comparison of procoagulant activities in extracts of normal and malignant human tissue. $J$. Natl. Cancer Inst. 62: 773-776, 1979. 
112. Hilgard $P$. Whur $P$. Factor $X$ activating activity from Lewis lung cancinoma. Br. S. Cancer 4: $642-643,1980$.

113. Curatolo L., Colluccii M., Cambini A.L., Poggi A. Morasea L. Donati M.B., Semeraro $N$. Evidence that cells from experimental tumours can activate coagullation factor X. Br. J. Cancer 40: 228-233, 1979 .

11.4. Colucci M., Curatolo L, Donati M.B., Semeraro N. Cancer cell procoagulant activity: evaluation by an amidolytic assay. Thromb. Res. 18:589-505, 1980 .

115. Dvorak H.F., Van Dewater L., Bitzer A.M., Dvorak A.M., Anderson D., Harvey V.S., Bach R., Davis G.L., De Wolf W., Carvaliho A.C.A. Procoagulant activity associated with plasma membrane vesicles shed by cultured tumor cells.

Cancer Res. 43: 4334-4342, 1983

116. Donati M.B., Gambacorti C., Passarini B., Falanga A., Fossati Gi., Semeraro N. Cancer procoagulant (factor $X$ activaton) in tumor cels from patients with malignant melanoma. Thromb. Maemostas $54: 259,1985$.

117. Eiseman, G. Stefanini M. Thromboplastic activity of leukemic white cells. Proc Soc. Exp. Biol. Med. 86: 763, 1954.

118. Goualt-Hielman M., Chardon E., Sultan E., Josse F. The procoagulant factor of leukaemic promyelocytes: demonstration of immunologic cross-reactivity with human brain tissue factor. Br. J. Haematol. 30: 15y-158, 1975 .

119. Gark S.K., Niemetz J. Tissue factor activity of normal and leukemic cells. Blood 42: 729-735, 1973 .

120. Hudig D., Rapaport S.I., Bajaj S.P. Tissule factor-like activity of the human monocyte tumor cell line U 937. Thromb. Res. 27:321-332, 1982.

121. Rickles F.R., Elion G., Ervan V.A., Viola M. Unpublished observation.

122. Al-Mondhiry $\mathbf{H}$. Tumor interaction with hemostasis: The rationale for the use of platelet inthibitors and anticoagularnts in the treatment of cancer.

Am. J. Maematol 16:19.3-202, 1984.

123. Zacharski L.R., Memoli V.A., Rousseau S.M. Extrinsic coagulation activation in situ in renal cell carcinoma (RCC). Thromb. Haemostas. 54: 258, 1985.

124. Evers J.L., Patel J., Madeja J.M., Schneider S.L., Hobilka G.H., Camiollo S.H., Markus G. Plasminogen activator activity and composition in human breast cancer. Cancer Res. 42: 219-226, 1983.

125. Carlsen S.A., Ramshaw J.A., Warrington R.C. Involvement of plasminogen activator production with tumor metastases in a rat model. Cancer Res. 44: 3012-3016, 1984.

126. Eisenbach L., Segal S., Feldman M. Proteolytic enzymes in tumor metastasis. 1. Plasminogen activator in clones of Lewis lung carcinoma and T10 sarcoma. J. Natl. Cancer Inst. 74: 77-85, 1985

127. Mussoni L., Acero R., Conforti M.G., Riganti M „, Mantovani A., Donati M.B. Enhanced expression of plasminogen activator (PA) activity by tumor-associated macrophages (TAM). Thromb. Haemostas. 54: 162, 1985.

128. Barrett J.C." Sheela S. Plasminogen activator in metastasis. Im: Tumor Invasion and Metastiasis. Liotta L.E. Hart I.R. (eds.) Martinus Nijhoff Publishers.

The Mague/Boston/London. 359-374, 1982.

129. Butler W.B., Kirkland W.L., Gargala T.L., Goran NN., Kelsey W.H., Berlinski P.J. Steroid stimulation of plasminogen activator in human breast cancer cell line (MCF-7). Cancer Res. 43: 1637-1641, 1983.

130. Duffy M.J., O'Grady P., Lijnen H.R. Tissue-type plasminogen activator; correlation with oestradiol receptors in human breast carcinomas. Br. J. Cancer 53:437, 1986.

131. Aoki N., Harpel P.C. Inhibitors of the fibrinolytic enzyme system.

Sem. Thromb. Haemostas. 10: 24-41, 1984.

132. Aoki N. Natural inhibitors of fibrinolysis. Prog. Cardiovasc. Dis. 21:267-286, 1979.

133. Aoki N., Moroi M., Matsuda M., Tachlya K. The behaviour of alpha-2-plasmin inhibitor in fibrinolytic states. J. Clin. Invest. 60:361-369, 1977.

134. Kahie L.H., Avrisati G., Lamping R.J., Moretti T., Mandelli F. , ten Cate J.W.

Turnover of alpha-2-antiplasmin in patients with acute promyelocytic leukemia. 
Scand. J Clin Lab. Inwest 45, Suppl. 178:75-80, 1985.

135. Poggl A., Mussoni L., Komblihtt L., Ballabio E., de Gaetano G., Donati M.B.

Warfarn enantomers, anticoagulation and experimentall fumour metastases.

Lancet i: $163-164,1978$.

136. Berkarda F.B. d'Souza J.P., Bakemeier R.F. The effect of anticoagulants on tumor growth and spread in mice. Proceedings of A.A.C.R. 15:99, 1974.

137. Hilgard P. The use of oral anticoagulants in tumour therapy. In: Malignancy and the Haemostatic System. Donali M.B. Davidson J.F. Garattini S. (eds.). Raven Press, New York. $103-111,1981$.

138. Hoover H.C., Jones D., Ketcham A.S. The optimal level of anticoagulation for decreasing experimental metastases. Surgery 79: 625 630, 1976.

139. Brown J.M. A gtudy of the mechanism by which anticoagulation with wartarin inhibits blood born metastases. Cancer Res. 33: 1217-1224, 1973.

140, Kirsch W.M., Schullz D., van Buskirk J.J., Young E.E. Effects of sodium warfarin and other carcinostatic agents on malignant cells: a study of drug synergy.

I. Med. 5; 69-82, 1974

141. Thornes R.D., Edlow D.W., Wood J.S. Inhibition ofl locomotion of cancer cells in vivo by anticoagulant therapy. I. Effects of sodium warfarin on $V 2$ cancer cells, granulocytes, lymphocytes and macrophages in rabbits. John. Hopk. Med. J. 123: $305,1968$.

142. Chllebowski R.T., Dietrich M., Akman $\mathbf{S}_{m, 4}$ Block J.B. Vitamin $K_{3}$ inhibition of malignant murine cell growth and human tumor collony formation. Cancer Treat. Rep. 69:527-532, 1985.

143. Maat B. Sellective macrophage inhibition abolishes wartarin-induced reduction of metastases. Br. J. Cancer 41:313-316, 1980.

144. Thornes R.D. Oral anticoagulant therapy of human cancer. J. Med. 5: 83-91, 1974.

145. Thornes F.D. Adfuvant therapy of cancer via the cellular immune mechanism of fibrin by induced fibrinolysis and oral anticoagulants. Cancer 35: 91-97, 1975.

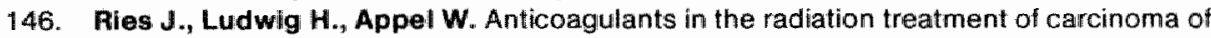
the fernale genitalia. Med. Welt 38: 2042-2047, 1968 .

147. Hoover H.C.,, Ketcham A.S., Millar R.C., Gralnick M.R. Osteosarcoma: Improved survival with anticoagulation and amputation. Cancer $4 \pi: 2475-2480,1978$ :

148. Zacharski L.R., Henderson W.G., Rlickles F.R. et al. Effect of warfarin on survival in small cell carcinoma of the lung. J.A.M.A. 245:831-835, 1981.

149. Stanford C.F. Anticoagulants in the treatment of small cell carcinoma of the bronchus. Thorax 31: 113-116, 1979 .

150. Chahinian A.P., Ware J.H., Zimmer B., Comis R.L., Perry M.C., Hirsch V., Skarin A.T., Raich P.C., Weiss R.B., Carey R.W. (CALGB). Evaluation of anti-coagulation with warfarin and of alternating chemotherapy in extensive small cell cancer of the lung (SCCL), Proc. of Am. Soc. Clin. Onc. 225, 1984.

151. Zacharski L.R., Henderson W.G., Rickles F.R. et all. Effect of warfarin anticoagulation on survival in carcinoma of the lung, colon, head and neck, and prostate. Final Report of VA Cooperative Study 75, Cancer 53: 2046-2052, 1984.

152. Gaffney P.J." Thrombosis: a molecular approach to therapy. Nature 290: 445-446, 1981.

153. Smlth R.A.G., Dupe R..J., English P.D., Green J.. Fibrinolysis with acyl-enzymes. a new approach to thrombolytic therapy. Nature 290: 505-508, 1981.

154. Sherry $\mathbf{S}$. Tissue plasminogen activator (1-PA), will it fulfil its promise? N. Engl. J. Med. 313:1014-1017, 1985. 


\section{Outline of investigations}

The theoretical relevance of tissue factor and its subsequent activation of factor VII in relation to cancer led us to do a preliminary investigation of factor VII activation in patients with benign and malignant disease of the prostate. An indication of activated factor VII was found in the peripheral blood of patients with metastatic cancer of the prostate (1).

Before we decided to investigate the activity state of factor VII in a large number of patients with cancer of the prostate, kidney and breast with and without metastases, we thoroughly tested the validity of our method determining plasma factor VIla in several experiments.

The following investigations have been performed."

1. A new, cheap way of determining activated factor VII using an artificial factor VIII deficient reagent in a one stage clotting assay, was developed previously in this laboratory (2).

2. The test, which could be applied on a large scale, was evaluated in plasma of women using oral contraceptives (chapter III).

3. The emerging questions on the cold-promoted activation of factor VII were investigated in plasmas deficient in different coagulation factors to further determine the practical value of the test (chapter IV).

4. Blood coagulation parameters that were theoretically relevant in relation to cancer, among which factor VIla, were studied in 106 patients with cancer of the breast, prostate and kidney. Most patients were participating in a longitudinal follow-up (chapter V).

5. The pharmacological interaction of a combined hormonal treatment and its effect on hormonal and haemostatic parameters were studied in 20 postmenopausal patients with advanced breast cancer (chapter VI, VII).

\section{References}

1. van Deijk W.A., van Dam-Mieras M.C.E., Muller A.D. Activation of factor VII in patients with carcinoma of the prostate, a preliminary report.

Haemostasis 13: 198-200, 1983.

2. Hemker H.C., Muller A.D., Gonggrijp R. The estimation of activated human blood coagulation factor VII. J. Mol. Med. 1: 127-134, 1976. 



\section{Evaluation of a coagulation assay determining the activity state of factor VII in plasma}

Based on: W.A. van Deijk, M.C.E. van Dam-Mieras, A.D. Muller, H.C. Hemker. Evaluation of a coagulation assay determining the activity state of factor VII in plasma. Haemostasis 13: 192-197, 1983.

\section{Introduction}

In the preliminary phase of a clinical investigation into the activation of coagulation enzymes in the circulating blood of cancer patients we critically assessed the factor VII activation test described by Hemker et al (1). The test system described allows the measurement of the degree of activation of factor VII in plasma and is based on the use of both bovine and human brain thromboplastin, together with an artificial factor VII deficient reagent. The latter can be prepared on a relatively large scale which makes it possible to measure factor VII activation in a large series of patients, as might be applicable in epidemiologic studies (2).

The usefulness of the test was assessed by the measurement of factor VII activation during incubation of pooled plasma at $4^{\circ} \mathrm{C}$. Because of the high rate of occurrence of cold-promoted activation of factor VII, plasma of women using oral contraceptive agents was used (3). Because differences in the time course of activation of factor VII in plasma during incubation in the cold in glass and plastic containers have been reported in the literature $(4,5,6)$ we also investigated this aspect.

It will be shown that the test system described adequately measures factor VII activation and that, because of the influence of the incubation conditions upon the degree of factor VII activation, rigorous standardization of the blood sampling and test procedures is compulsory.

\section{Materials and methods}

Factor VII deficient reagent

An artificial factor VII deficient reagent was prepared by a modification of the method of Lechner and Deutsch (1). The artificial reagent contained: $64 \%$ human factor $X, 72 \%$ bovine factor $V, 74 \%$ human factor II and $2,25 \mathrm{~g} / \mathrm{I}$ fibrinogen. The results obtained with this reagent showed a perfect correlation with those obtained with plasma congenitally deficient in factor VII (1). The factor VII 
concentration of the reagent, determined as described earlier, was $1.68 \%(1)$.

\section{Thromboplastins}

Human and bovine thromboplastins were prepared as described by van Dam-Mieras et al (7). Prior to use thromboplastin solutions, were prewarmed at $37^{\circ} \mathrm{C}$ for minimally 20 minutes.

Buffer

Veronal acetate $(0.15 \mathrm{M}, \mathrm{pH} 7.4)$.

Sampling procedure

Blood from women using OCAs was obtained by venipuncture after as short a period of stasis as possible and was collected in plastic tubes containing trisodium citrate. $2 \mathrm{H}_{2} \mathrm{O}$ (final concentration $0,109 \mathrm{M}$ ). The first few millilitres of blood were discarded. Platelet poor plasma was prepared by centrifugation of blood for $10 \mathrm{~min}$. at $3.000 \mathrm{~g}$ and platelet free plasma by centrifugation of platelet poor plasma for 30 min. at $12.000 \mathrm{~g}$. During blood sampling and plasma preparation procedures only plastic materials were used. Platelet free plasma was pooled and stored in $1 \mathrm{ml}$ portions at $-20^{\circ} \mathrm{C}$ for 24 hours prior to testing.

Incubation at $4^{\circ} \mathrm{C}$

Immediately after thawing, plasma samples were kept at $4^{\circ} \mathrm{C}$ in plastic or glass tubes. After $0,1,2,4,24$ and 48 hours, samples were taken, diluted in buffer and screened for factor VIII activation.

\section{Pooled normal plasma}

This was obtained by pooling equal amounts of platelet free plasma from at least 30 healthy individuals ( 15 males and 15 females, not using oral contraceptive agents, average age 30 years) and stored in small portions at $-80^{\circ} \mathrm{C}$ until use.

Determination of factor VII activation

A sample of diluted plasma $(0.1 \mathrm{ml})$, factor VII deficient reagent $(0.1 \mathrm{ml})$ and human or bovine thromboplastin $(0.1 \mathrm{ml})$ were incubated during 30 sec. in a glass tube at $37^{\circ} \mathrm{C}$. The coagulation was initiated by the addition of $0.1 \mathrm{ml} \mathrm{CaCl}(33 \mathrm{mM})$ and the coagulation time recorded. All determinations were carried out in duplicate.

The degree of factor VII activation in the test plasma was determined by the ratio of the plasma factor VII level determined with bovine thromboplastin and the plasma factor VII level determined with human thromboplastin as has been suggested previously (8). 
Reference tables

Reference curves for the human and bovine test system were constructed by registrating the clotting times obtained when a series of dilutions of pooled normal plasma was used as a source of factor VII in a factor VII deficient medium (Table 1). From these curves reference tables can be derived using a computer program which make it possible to determine the factor VII concentration in test plasma in a well-defined range, set by the standard concentrations used to construct the reference tables and even slightly beyond ( 1 , Table 2).

Table $\mathbb{~}$.

Coagulation times obtained when normal human plasma is incubated with human or bowine thromboplastin (TP) in a factor VII deficient reagent.

\begin{tabular}{lll}
\hline $\begin{array}{l}\text { Plasma } \\
\text { concentration } \\
\text { \% v/v }\end{array}$ & \multicolumn{2}{l}{ Coagulation times (sec.) } \\
\cline { 2 - 3 } & human TP & bovine TP \\
\hline 20 & 21.8 & 46.3 \\
10 & 26.6 & 54.0 \\
5 & 32.0 & 6.4 .8 \\
2.5 & 38.0 & 73.3 \\
1.67 & 41.7 & 80.3 \\
1.25 & 45.3 & 87.8 \\
1.00 & 48.5 & 86.1 \\
0.50 & 57.7 & 90.5 \\
- & 71.0 & 96.6 \\
\hline
\end{tabular}

Incubations are carried out in glass at $37^{\circ} \mathrm{C}$.

SD $1.0 \%$. Minimallime: with human TP $18.8 \mathrm{sec}$; with bowine TP $34.6 \mathrm{sec}$. 
Table 2 .

A reference table which in this example has been constructed the curve using the bovine fest system as shown in table 1 . An example will clarify its use:

suppose that testing a 1:10 dilution of a patient plasma sample leads to a clotting time of 52.3 sec. From the table the corresponding percentage of factor Vll in this plasma dilution can be derived, which is 11.51. This number has to be multiplied by the factor of dilution to obtain the percentage of factor Win in the whole test plasma, in this case $x 10$. So the lest plasma appears to contain $115.1 \%$ factor VII.

\begin{tabular}{|c|c|c|c|c|c|c|c|c|c|c|}
\hline \multirow{2}{*}{$\begin{array}{l}\text { Coagulation- } \\
\text { the (sec. }\end{array}$} & \multicolumn{10}{|c|}{ Concentrations (\%) } \\
\hline & .0 & .1 & 2 & 3 & .4 & .5 & 6 & .7 & 8 & .9 \\
\hline 46 & 20.59 & 20.37 & 20.15 & 19.93 & 19.72 & 1951 & 1930 & 19.10 & 1890 & 18.70 \\
\hline 47 & 18.51 & 1832 & 18.13 & 17.95 & 17.77 & 17.59 & 17.42 & 1725 & 1708 & 16.91 \\
\hline 40 & 16.75 & 16.59 & 16.43 & 16.27 & 16.12 & 15.97 & 15.82 & 15.67 & 15.53 & 1530 \\
\hline 49 & 115.24 & 15.10 & 14.97 & 14.83 & 14.70 & 14.57 & 1.4 .44 & 14.31 & 14.18 & 14.06 \\
\hline 50 & 13.9 .4 & 1301 & 13.69 & 13.58 & 13.46 & 13.35 & 13.29 & 13.12 & 13.01 & 12.90 \\
\hline $5 \%$ & 12.79 & 12.69 & 1258 & 12.48 & 1.2 .37 & 1227 & 12.17 & 12.07 & 1198 & 11.88 \\
\hline 52 & 11.78 & 11.69 & 11.60 & 11.51 & 11.41 & 11,32 & 11.24 & 91.15 & 11.08 & 10.97 \\
\hline 53 & 10.89 & 1080 & 1072 & 10.64 & 10.56 & 10.48 & 10.40 & 10.32 & 10.24 & 10.16 \\
\hline 54 & 1009 & 10.01 & 9.94 & 9.86 & 9.79 & 9.72 & 9.65 & 9.58 & 9.51 & 9.4 .4 \\
\hline 55 & 937 & 9.30 & 923 & 9.16 & 9.10 & 9.03 & 8.97 & 8.90 & 8.84 & 0.78 \\
\hline 56 & 9.72 & 8.65 & 8.59 & 6.53 & 8.47 & 8.41 & 8.35 & 8.29 & 8.24 & 18.18 \\
\hline 57 & 9.12 & B.07 & 8.01 & 7.96 & 7.90 & 7.85 & 7.79 & 7.74 & 7.69 & 7.63 \\
\hline 58 & 7.58 & 7.53 & 7.48 & 7.43 & 7.38 & 7.33 & 7.28 & 7.23 & 7.18 & 7.13 \\
\hline 59 & 7.09 & 7.04 & 6.99 & 6.95 & 6.90 & 6.85 & 6.81 & 6.76 & 6.72 & 6.67 \\
\hline 60 & 6.63 & 6.59 & 6.54 & 6.50 & 6.46 & 642 & 637 & 6.33 & 6.29 & 6.25 \\
\hline$\theta 1$ & 6.21 & 6.17 & 6.13 & G.CO: & 6.05 & 6.01 & 5.97 & 593 & 5.90 & 5.86 \\
\hline 62 & 5.82 & 5.78 & 5.75 & 5.71 & 5.67 & 5.64 & 5.60 & 5.56 & 5.53 & 5.49 \\
\hline 63 & 5.46 & 5.42 & 5,39 & 5,35 & 532 & 529 & 5.25 & 5.22 & 519 & 5,15 \\
\hline 64 & 5.12 & 5.09 & 5.06 & 5.02 & 4.99 & 496 & 4.913 & 4.90 & 4.87 & 4.8 .4 \\
\hline 65 & $4.8 H$ & 4.78 & 4.75 & 4.72 & 4.69 & 466 & 4.6 .3 & 4.60 & 4.57 & 4.54 \\
\hline 66 & 4.58 & 4.48 & 4.46 & 4,43 & 4.40 & 4.37 & 4.35 & 4.32 & 4.29 & 4.26 \\
\hline 67 & 4.24 & 4.21 & 4.18 & 4.16 & 4.113 & 4.11 & 4.08 & 4.05 & 4.03 & 4,00 \\
\hline 68 & 3.98 & 3.95 & 3.93 & 3.90 & 3.88 & 3.85 & 3.83 & $3.8 \pi$ & 3.78 & 3.76 \\
\hline 69 & 3.74 & 3.71 & 3.69 & 3.66 & 3.64 & 362 & 3.60 & 3.57 & 3.55 & 3.53 \\
\hline 70 & 3.51 & 3.48 & 3.46 & 3.44 & 3.42 & 3.40 & 3.37 & 3.35 & 3.33 & 3.31 \\
\hline 71 & 3.29 & 3.27 & 325 & 3.23 & 3.21 & 3.18 & 3.16 & 3.14 & 3.12 & 3.10 \\
\hline 72 & 3.08 & 3.06 & 304 & 3.02 & 3.00 & 2.98 & 2.97 & 295 & 2.93 & 2.91 \\
\hline 73 & 2.89 & 2.87 & 2.85 & 2.83 & 281 & 2.80 & 2.78 & 2.76 & 2.74 & 2.72 \\
\hline 74 & 2.70 & 2.69 & 2.67 & 2.65 & 2.63 & 2.6 .2 & 2.60 & 2.58 & 2.56 & 2.55 \\
\hline 75 & 2.53 & 2.51 & 2.50 & 2.48 & 2.46 & 2.45 & 2.43 & 2.41 & 2.40 & 2.38 \\
\hline 76 & 2.36 & 2.35 & 2.33 & 2.31 & 230 & 2.28 & 2.27 & 2.25 & 2.24 & 222 \\
\hline 77 & 2.20 & 2.19 & 217 & 21 1 变 & 2.14 & 2.13 & 2.11 & 2.10 & 208 & 2.07 \\
\hline 78 & 2.05 & 2.04 & 202 & 2.01 & 1.99 & 1.98 & 1.97 & 1.95 & 1.94 & 1.92 \\
\hline 79 & 1.91 & 1.89 & 1.88 & 11.97 & 1.85 & 1.8 .4 & 1.93 & $1 . B 1$ & 1.80 & 1.78 \\
\hline $\mathrm{BO}$ & 1,77 & 1.76 & 1.74 & 1.73 & 4.72 & 1.70 & 1.69 & 1.68 & 1.66 & 165 \\
\hline 81 & 1.64 & 1.63 & 1.61 & 1.60 & 1.59 & 1,58 & 1.56 & 1.55 & 9.54 & 1.52 \\
\hline 82 & 1.51 & 1.50 & 149 & 1.48 & 1.46 & 145 & 1.44 & 1.43 & 1.42 & 1.40 \\
\hline 83 & 1.39 & 1.38 & 1.37 & 1.36 & $\forall .34$ & 1.33 & 4.32 & 1.31 & 1,30 & 1.29 \\
\hline 34 & 1.28 & 1.260 & 1.25 & 1.24 & 1.23 & 1.22 & 1,21 & 1.20 & 11.19 & 1.17 \\
\hline 85 & 1.16 & 1.15 & 1.14 & 1.13 & 1.12 & 1.11 & 1.10 & 1.09 & 1.06 & 1.07 \\
\hline 816 & 1.06 & 1.05 & 1.04 & $1,0.3$ & 1.02 & 1.00 & 0.99 & 0.98 & 0.97 & 0.96 \\
\hline 87 & 0.95 & 0.94 & 0.93 & 0.92 & 0.91 & 0.90 & 0.89 & 0.88 & 0.87 & 0.96 \\
\hline 88 & 0.85 & 0.85 & 0,84 & 0.83 & 0.82 & 0.81 & 0.80 & 0.79 & 0.78 & 0.77 \\
\hline 89 & 0.76 & 0.75 & 0.74 & 0.73 & 0.72 & 0.71 & 0.70 & 0.69 & 0.69 & 0.68 \\
\hline 90 & 0.67 & 0.66 & 0.65 & 0.64 & 0.63 & 0.62 & 0.61 & 0.61 & 0.60 & 0.59 \\
\hline
\end{tabular}




\section{Results}

In figure 1 the results of the experiments are shown in which plasma from women using OCAs was incubated at $4^{\circ} \mathrm{C}$. As can be seen in this figure, the amount of factor VII measured in the test system using human thromboplastin changes appreciably less during incubation at $4^{\circ} \mathrm{C}$ than the apparent amount of factor $\mathrm{VII}$ measured in the test using bovine thromboplastin.

It can further be concluded that, although the time course of factor VII activation during incubation in glass and plastic containers is different, the ultimate degree of factor VII activation is very similar in both materials.

Furthermore, the curves obtained with different dilutions of the sample are approximately parallel. As the samples containing relatively high plasma concentrations (5 or $10 \%$ ) produce extremely short coagulation times which fall beyond the validity range of the reference tables (1), coagulation times instead of factor VII levels had to be used on the ordinates in figure 1. In test samples that contain a lower amount of plasma the factor VII concentration can be determined in the usual way. Therefore, in the figures 2-5 factor VII activity is plotted instead of clotting times.

In the figures 2 and 3 the increase in factor VII concentration in plasma of women using OCAs during incubation at $4^{\circ} \mathrm{C}$ in glass as determined with human and bovine thromboplastin respectively is shown. In the figures 4 and 5 the same experiment is depicted for the incubation in plastic. As would be expected from earlier observations, the increase in factor VII activation during incubation in the cold was very pronounced when assayed with bovine thromboplastin and much less evident when assayed with human thromboplastin (8). As will be discussed below, the activity state of factor VII in plasma can best be expressed by the ratio (fig. 6 and 7 ):

Factor VII estimated with bovine thromboplastin (factor VIIb)

Factor VII estimated with human thromboplastin (factor VII ) 

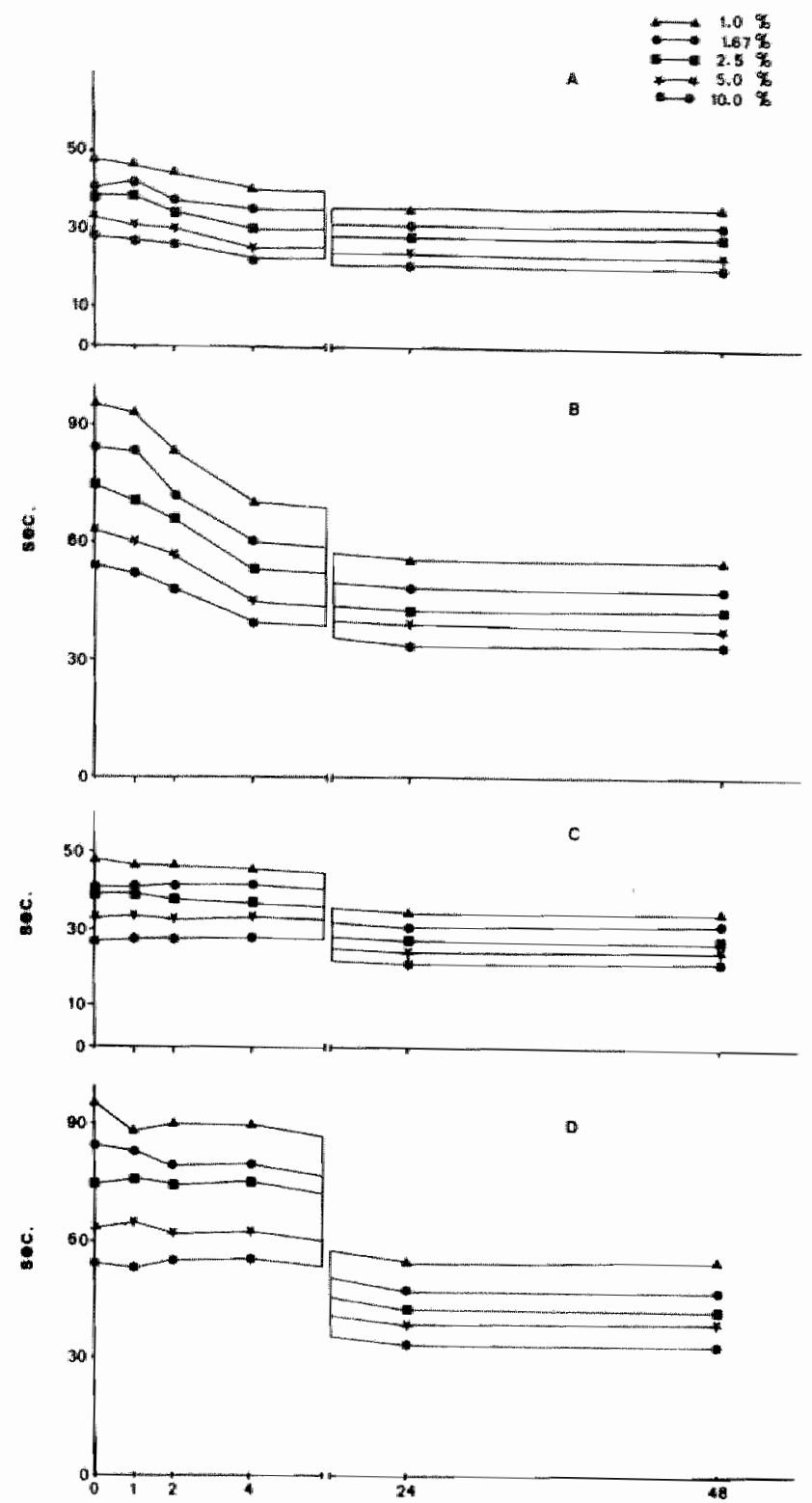

hours

Figure 1. Shartening of the one stage test for factor VII in the course of time in several dilutions of a sample of pooled plasma of women using OCAs during incubation in the cold. In $A$ and $B$ incubation was carried out in glass, and in $C$ and $D$ in plastic. In $A$ and $C$ human thromboplastin was used in the test mixture, while in $B$ and $D$ bovine thromboplastin was used. 


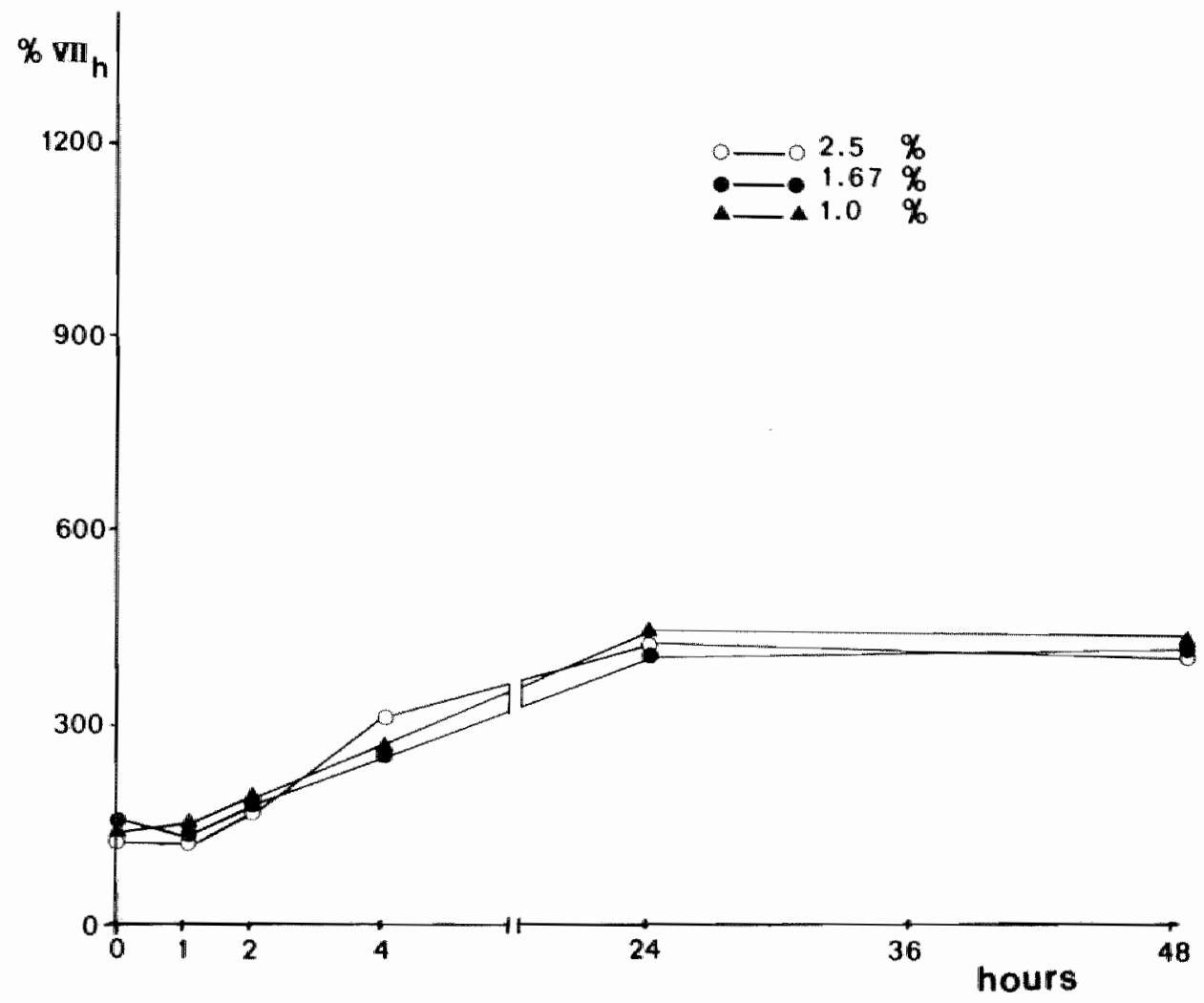

Figure 2. Activation of factor VIll in plasma during incubation at $4^{\circ} \mathrm{C}$ in glass tubes. The factor VIll activity after incubation is measured with human brain thromboplastin in several plasma dilutions. 


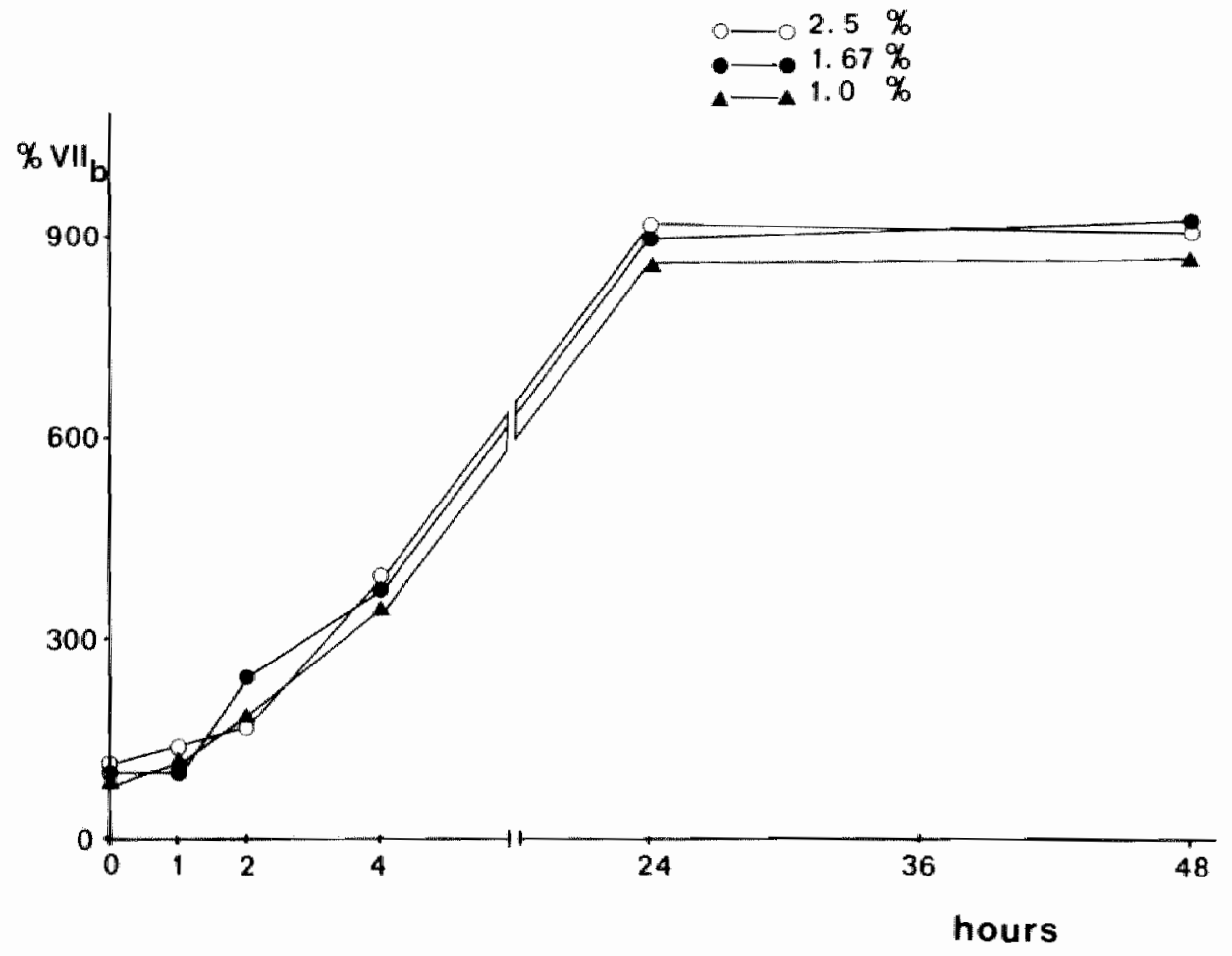

Figure 3. Activation of factor VII in plasma during incubation at $4^{\circ} \mathrm{C}$ in glasis lubes. The factor VII activity after incubation is measured with bovine thromboplastin in several plasma dilutions. 

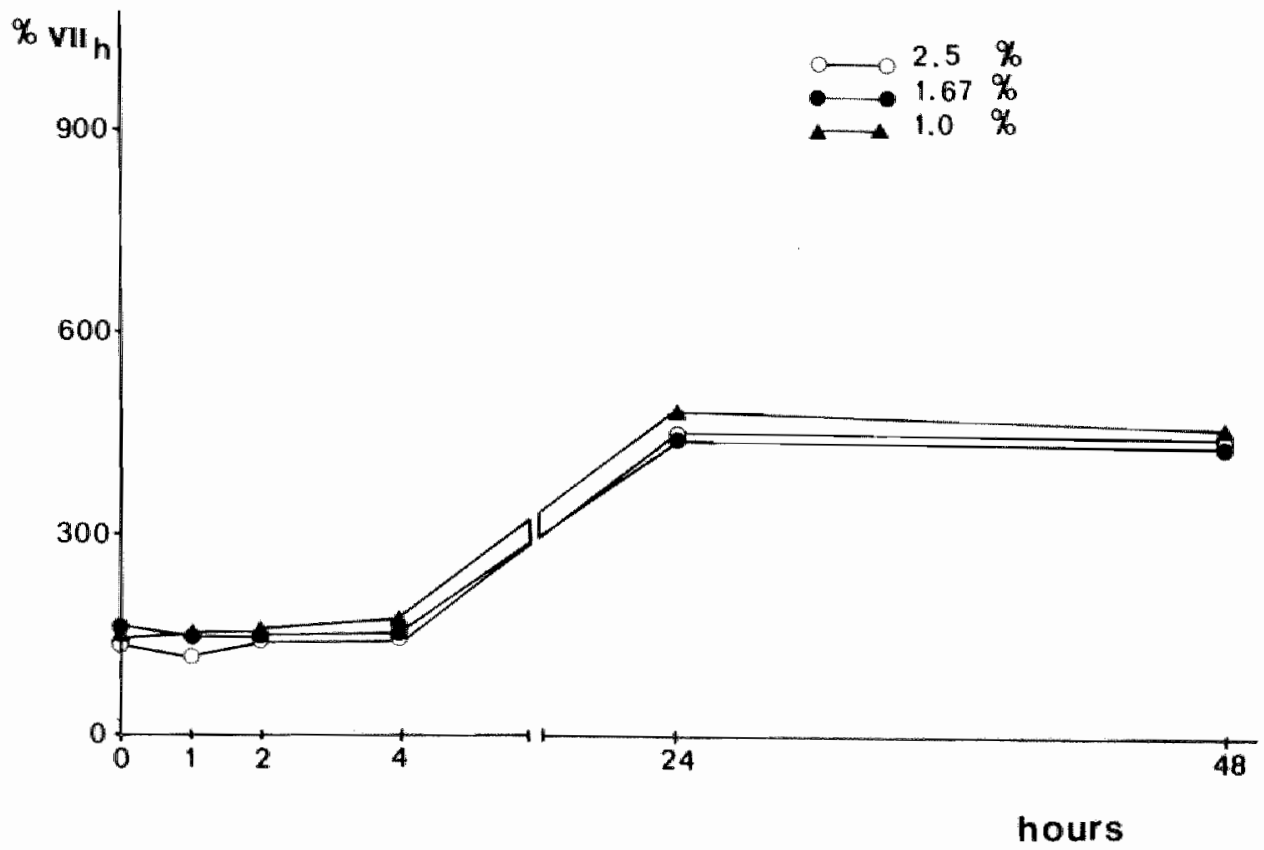

Figure 4. Activation of factor VIII in plasma during incubation at $4^{\circ} \mathrm{C}$ in plastic tubes. The factor VII activity after incubation is measured with human thromboplastin in several plasma dilutions. 

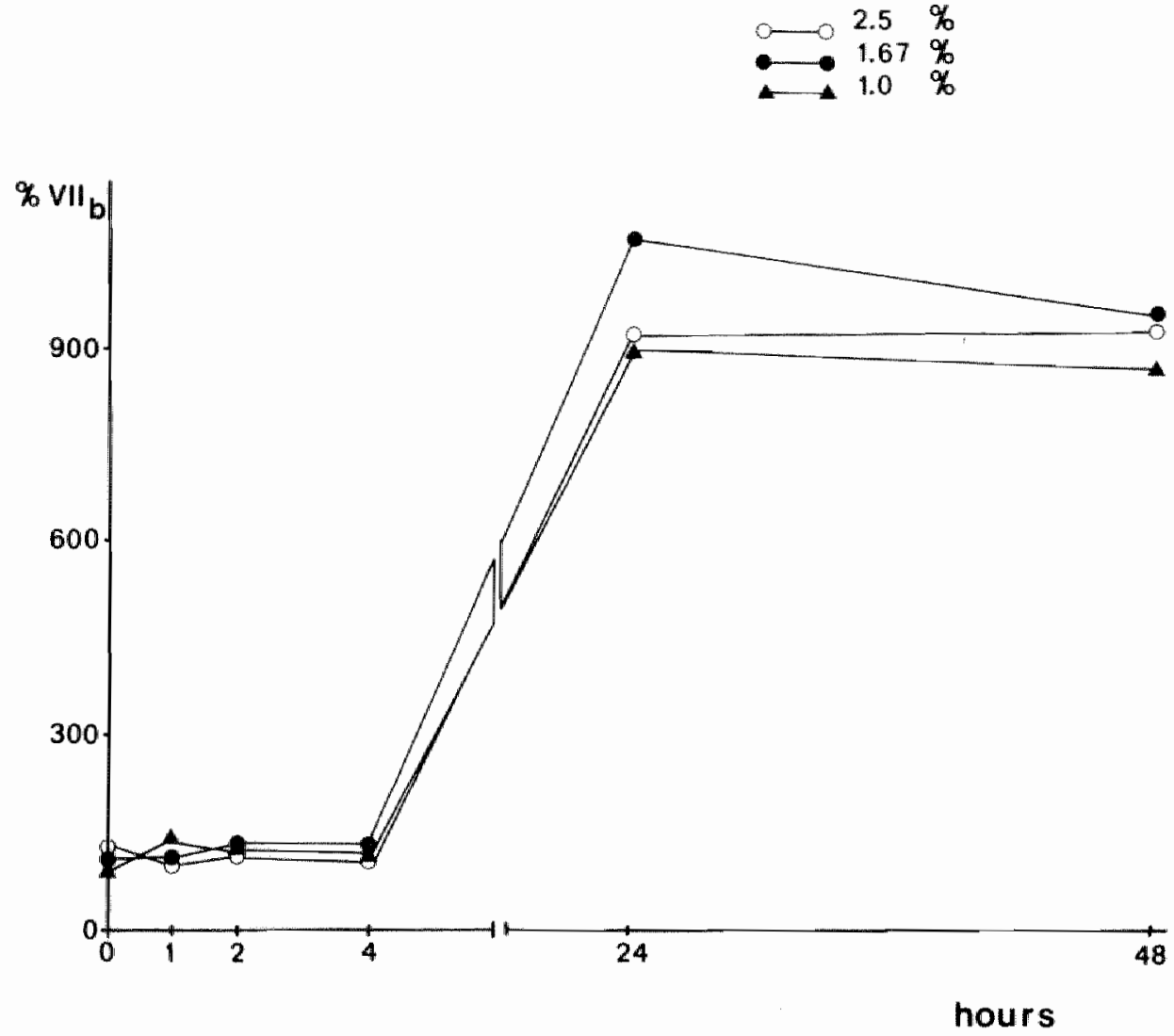

Figure 5. Activation of factor VII in plasma during incubation at $4{ }^{\circ} \mathrm{C}$ in plastic tubes. The factor VII activity after incubation is measured with bovine thromboplastin in several plasma dilutions. 


$$
\begin{array}{r}
02.5 \% \\
-\quad 1.67 \% \\
-\quad 1.0 \%
\end{array}
$$

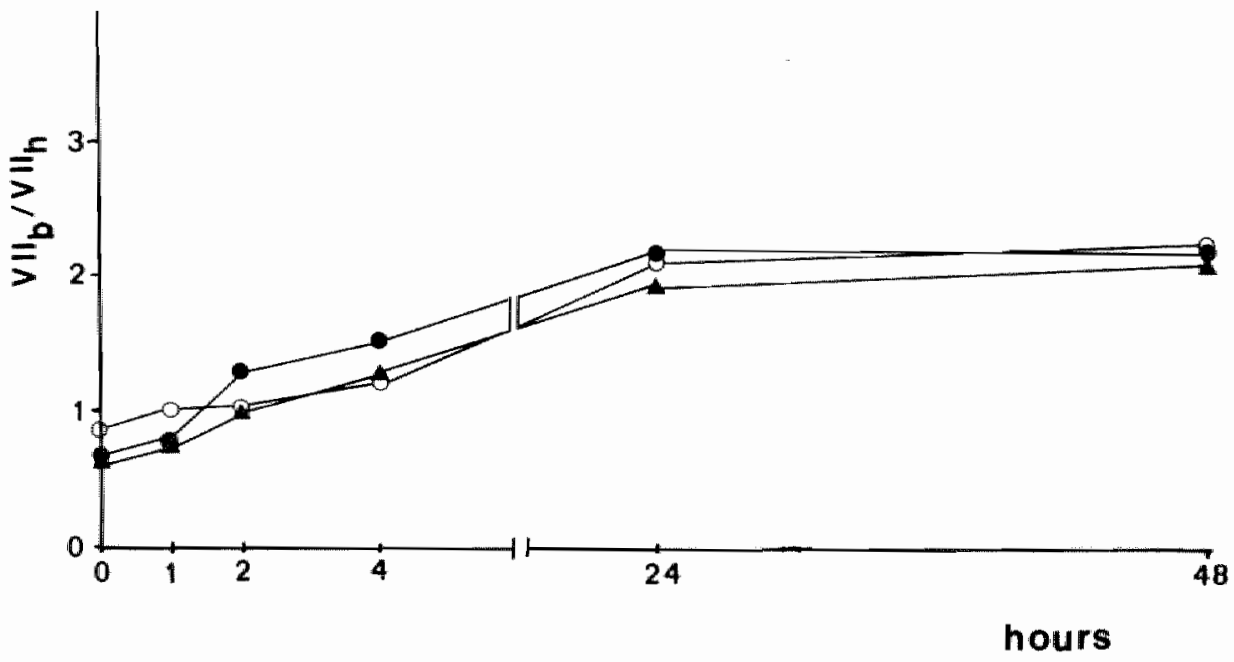

Figure 6. Factor $\mathrm{V} / \mathrm{l}_{\mathrm{b}} \mathrm{N} \mathrm{II}_{\mathrm{h}}$ ratio in plasma during incubation at $4^{\circ} \mathrm{C}$ in glasis tubes. 


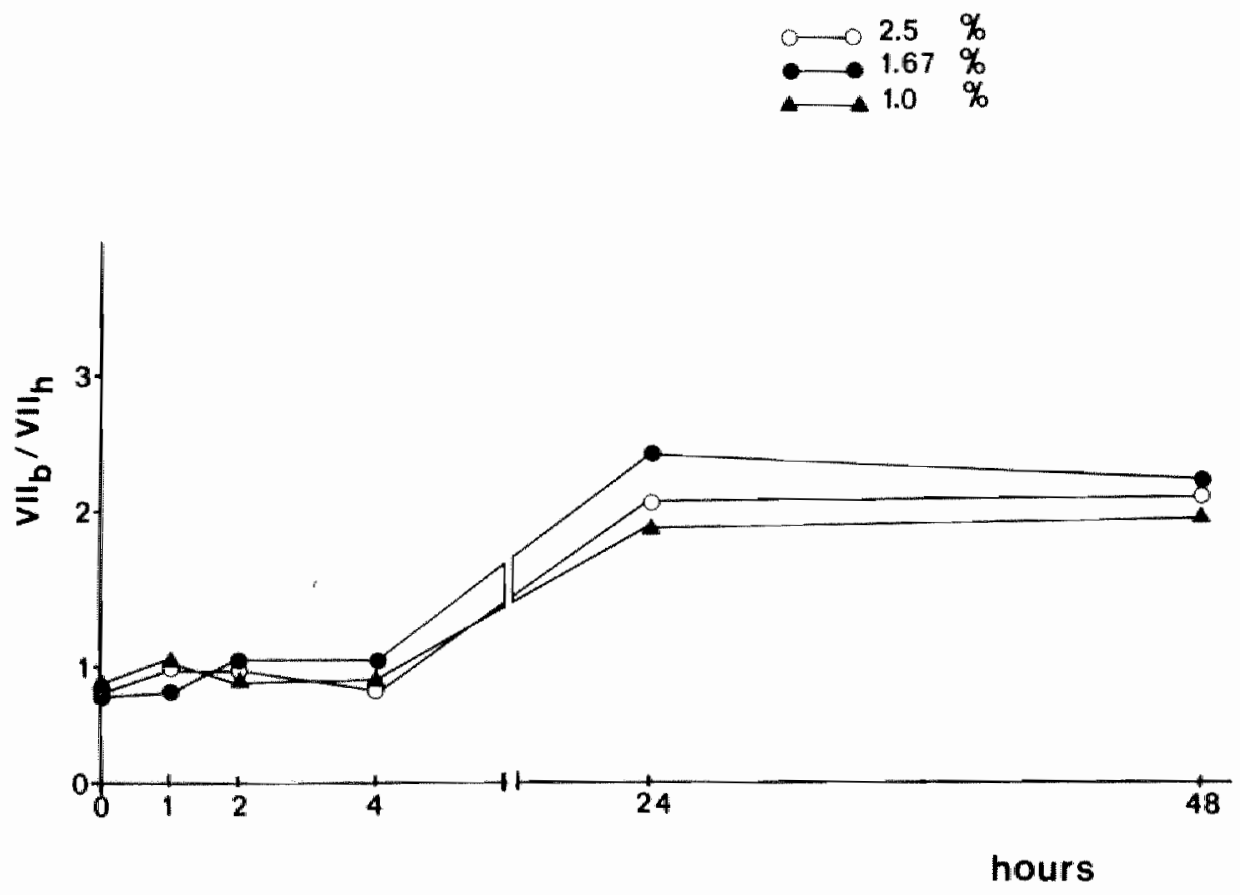

44 Figure 7 . Factor $\mathrm{V} / \mathrm{I}_{\mathrm{b}} / \mathrm{V} / \mathrm{I}_{\mathrm{h}}$ ratio in plasma during incubation at $4^{\circ} \mathrm{C}$ in plastic tubes. 


\section{Discussion}

As was shown previously by Hemker et al (8), bovine thromboplastin, in contrast with human thromboplastin, is hardly able to interact with human factor VII unless this factor has been previously activated. Although the exact initiation of the activation of the extrinsic pathway is still unknown (9), the observations of Hemker et al might be explained by assuming that the activation step of factor VII and not the combination step between thromboplastin and factor VII is rate limiting $(10,11)$.

Therefore, it must theoretically be possible to measure the state of activation of factor VII in plasma by exploring this difference in activity between thromboplastins from different species. The results presented here confirm this idea.

It is shown that a test system using bovine thromboplastin measures an important increase in factor VII activity during incubation at $4^{\circ} \mathrm{C}$, a situation which is known to produce factor VII activation. The test system using human thromboplastin, however, only shows a small increase in factor VII activity under these conditions, showing that the test is much less dependent, though not completely independent on the activity state of factor VII in the sample. This means that the sample handling, because it is known to influence factor VII activation, is compulsory to be rigorously standardized. In order to obtain a figure that is predominantly dependent upon the activation state of factor VII rather than upon the absolute amount of this factor present we propose to use the quotient of the activities obtained with bovine and human thromboplastin respectively. Recently a new coupled amidolytic assay for factor VII has been described $(12,13)$. In the assay, the amount of factor VII in a test sample determines the amount of factor $X a$ which is generated in a mixture of purified factor $X$, tissue factor, and calcium; factor $X a$ is measured with a chromogenic substrate. In this amidolytic assay which indirectly measures factor VII, all factor VII is converted into its activated two chain form, so it will fail to detect the amount of factor VII which had already been activated in plasma. Therefore, a coagulation assay using human thromboplastin to initiate the coagulation reaction, was applied to measure the activity state of factor VII in plasma, because the clotting time will depend on the amount of native and activated factor VII in the test sample.

The authors proposed to determine the activity state of factor VII by the ratio of factor $V I I$ determined with the coagulation assay and factor VII determined with the amidolytic assay. The quotient of these activities indeed will vary with the activity state of factor VII, but, as human thromboplastin in a coagulation assay is relatively insensitive to factor Vlla, we prefer the assay based upon the use of coagulation assays with bovine and human thromboplastin. The 
methods described by van Dieijen-Visser et al and Seligsohn et al $(12,13)$ need the availability of purified factor $X$, which may be a practical difficulty in most clinical laboratories.

The spectrophotometric factor VII determination by Awvisati et al (14) employs congenital factor VII deficient plasma which is not abundantly available either. We therefore think that the determination of the activity state of factor VII by the use of coagulation assays with bovine and human thromboplastin is the most practical solution at the moment.

Our results, showing the differences in the time course of factor VII activation during incubation in the cold in glass and plastic, confirm the results that have been reported in the literature $(4,5,6)$. The ultimate stage of factor VII activation proved to be the same in both materials. The different mechanisms for factor $X I$ in the binding to glass and plastic materials as described by Mannhalter and Schiffman (15) might also apply to factor XII and kallikrein, leading to their slower activation in plastic compared to glass. As these factors are known to play an important role in the cold promoted activation of factor VII $(5,6)$, it is tempting to assume that similar mechanisms might play a role in the slower activation of factor VII in plastic compared to glass. As will be shown in chapter IV, under certain conditions factor II also plays a role in the cold-promoted activation of factor VII.

In conclusion, we can say that our test system adequately measures the activity state of factor VII if it is taken into account that rigorous standardization of blood sampling and test procedures is necessary. 


\section{References}

1. Hemker H.C., Swart A.C.W., Allink A.M.J. Artificiall reagents for factor VII and factor $X$, a computer program for obtaining reference tables for one-stage determinations in the extrinsic system. Thromb. Diath. Haemorrh. 27: 205-211, 1972

2. Meade T.W., Chakrabarti R., Haines A.P., North W.R.S., Stiring $Y$., Thompson S.G., Brozovic M. Haemostatic function and cardiovascular death: early results of a prospective study. Lancet i: 1050-1054, 1980.

3. Gidnnaes $\mathrm{H}$. Cold promoted activation of factor VIl. Occurrence and relation to sex hormones and antifertility compounds. Gynecol. Invest. 4:61-72, 1973:

4. Gidonnaes $H$. Cold promoted activation of factor VIl. I. Evidence for the existence of an activator. Thromb. Diath. Haemorrh. 28: 155-168, 1972 .

5. Gordon E.M., Ratnoff O.D., Jones P.K. The role of augmented Hageman factor (factor Xil) titers in the cold-promoted activation of factor VII and spontaneous shortening of the prothrombin time in women using oral contraceptives. J. Lab. Clin. Med 99:363-369, 1982.

6. Palmer R.N., Gralnick H.R. Cold-induced contact surface activation of the prothrombin time in whole blood. Blood 59:38-42, 1982.

7. van Dam-Mieras M.C.E., Muller A.D., Hemker H.C. Blood coagulation factors II, V, VII, VIII ${ }_{1} X, X$ and XI. Determination by clotting assays. In: Methods of Enzymatic Analysis, vol. 5. Bergmeyer H.U., Bergmeyer J, Grass/ M. (eds.). Verlag Chemie GmbH, Weintheim. F.R.G. $352-365,1984$.

8. Hemker H.C., Muller A.D., Gonggrijp R. The estimation of activated human blood coagulation factor VII. J. Mol. Med. 1: 127-134, 1976.

9. Zur M., Nemerson $Y$. Tissue factor pathways of blood coagulation; In: Bloom, Thomas. Haemostasis and thrombosis. Churchill Livingstone, London. 124-139, 1981.

10. Morrison-Silverberg S.A., Jesty J.. The role of activated factor $X$ in the control of bovine coagulation factor VII. J. Biol. Chem. 256: 1625-1630, 198 \%.

11. Zur M., Radcliffe R.D., Oberdick J., Nemerson $\mathrm{Y}$. The dual rolle of factor VII in bilood coagulation. J. Biof. Chem. 257: 5623-5631, 1982

12. van Dleijen-Visser M.P., van Wersch J., Brombacher P.J., Rosing J., Hemker H.C., van Dieijen G. Use of chromogenic peptide substrates in the determination of clotting factors II, VIII IX and $X$ in normal plasma and in plasma of patients treated with oral anticoagulants. Haemostasis $12: 247-255,1982$.

13. Sellgsohn U., Østerud B., Rapaport S.I. Coupled amidolytic assay for factor VIt: its use with a clotting assay to determine the activity state of factor VIl. Blood $52.978-988$, 1978 .

14. Avvisati G., ten Cate J.W., van Wijk E.M., Kahle L.H., Mariani G. Evaluation of a new chromogenic assay for factor $V / I$ and its application in patients on oral anticoagulant treatment. Br. J. Haemaf. 45: 343-352, 1980.

15. Mannhalter C., Schiffman S. Surtace absorption of factor XI. II. Evidence that different mechanisms are involved in binding to glass and plastic materials. Thromb Haemostas. $47: 214-217,1982$. 
The activity state of factor VII in plasma. Two pathways for the cold-promoted activation of factor VII

Based on: A.D. Muller, W.A. van Deijk, P.P. Devilee, M.C.E. van Dam-Mieras, H.C. Hemker. The activity state of factor VII in plasma. Two pathways for the cold-promoted activation of factor VIII. Br.J.Haematol. 62: 367-377, 1986.

\section{Introduction}

Factor VII activation has been described to occur in circulating plasma in different pathological situations $(1,2,3)$. Human factor VII is a single chain protein that can be converted to factor VIla, a two chain protein. This conversion is associated with an increase in activity as measured in a one stage test. The increase, however, is dependent on the type of thromboplastin used to initiate the reaction. Bovine thromboplastin interacts with human factor Vlla but hardly with human factor VII while human thromboplastin interacts with both human factor VII and factor VIla. The increase in activity with conversion of the single chain into the two chain form will therefore be much more pronounced when tested with bovine thromboplastin than with human thromboplastin. Therefore the state of activation of factor VII in plasma can be expressed by the ratio: factor $\mathrm{VII} / \mathrm{b}$ factor $\mathrm{V} \mathrm{II}_{\mathrm{h}}$ ( $\mathrm{b}=$ estimated with bovine thromboplastin; $\mathrm{h}=$ estimated with human thromboplastin). This test, as described by Hemker et al and evaluated as described in chapter III, was applied to further investigate its practical use by studying the pathway(s) that lead(s) to cold-promoted factor VII activation (4).

\section{Materials and Methods}

All chemicals used were of reagent grade; all solutions were made in distilled water;

Buffer. Veronal acetate $(0.15 \mathrm{M}, \mathrm{pH} 7.4)$

Hirudin was obtained from Sigma, St. Louis, U.S.A.

Thrombin was obtained from Serva, New York, U.S.A.

Prekallikrein activation was measured by the use of chromogenic substrate $\mathrm{S} 2302$ (Kabi Vitrum), as described by Alving et al (5).

Factor VII deficient reagent was prepared as mentioned in chapter III. 
Thromboplastins. Human and bovine thromboplastins were prepared as described in chapter III.

The collection and treatment of the samples, the incubation of plasma at $4^{\circ} \mathrm{C}$ and the determination of factor VII activation were also described in the previous chapter.

Pooled normal plasma was obtained as described in chapter III. The following samples were used: pooled human normal plasma; congenital deficient plasmas: II deficient $(n=1), V$ deficient $(n=2)$, VII deficient ( $n=2)$, VIII deficient $(n=6), \| X$ deficient $(n=3), X$ deficient $(n=3)$, XI deficient $(n=2)$, XII deficient $(n=2)$. In the results mean values of the data obtained with the individual factor deficient plasmas are given.

\section{Results}

Figure 1 shows the results of activation of factor VII obtained when pooled normal plasma is incubated at $4^{\circ} \mathrm{C}$ in glass and in plastic tubes. The apparent amount of factor VIl as measured with a test system using bovine thromboplastin (we shall call this test system the bovine test system) shows a five-fold increase during incubation at $4^{\circ} \mathrm{C}$. The apparent amount of factor VII as determined in a one stage test using human thromboplastin (the human test system) also increases during incubation at $4^{\circ} \mathrm{C}$ but to a lesser degree (about two-fold). It can also be concluded that, although the time course of factor VII activation during incubation at $4^{\circ} \mathrm{C}$ in glass and plastic tubes is different, the ultimate stage of factor VII activation is very similar in both materials. This also follows from figure 2 in which the ratio factor $\mathrm{V} / \mathrm{I}_{\mathrm{b}} /$ factor $\mathrm{V} / \mathrm{I}_{\mathrm{h}}$ is plotted.

The involvement of other cllotting factors in the process of coldpromoted factor VII activation has been studied by incubating congenital factor deficient plasmas at $4^{\circ} \mathrm{C}$, again in glass and plastic tubes. The results are shown in the figures 3-6. It can be concluded that cold-promoted activation of factor VII only takes place when the factors XII and of course VII are present in the plasma. In the absence of factor IX cold-promoted activation of factor VII is reduced to about $50 \%$. In factor VIII deficient plasma the results obtained in glass are similar to those obtained with factor $V$ deficient plasma, but in plastic no activation occurs in factor Vill deficient plasma. Because congenital factor II deficient plasma is hard to obtain we could only test one single plasma (results not shown). This plasma showed no factor VII activation upon storage at $4^{\circ} \mathrm{C}$. However, the initial factor $V I_{b} /$ factor $V I_{h}$ values for this preparation indicated that some factor VII activation might have occurred during sample preparation. The results confirm the involvement of the contact phase of blood coagulation in the process of cold-promoted activation, but also point to a role of factor II in this process. 
In order to further elucidate the role of factor II, or most probably that of its activation product thrombin, in the cold-promoted activation of factor VII, normal pooled plasma, supplemented with various amounts of the thrombin inhibitor hirudin was incubated at $4^{\circ} \mathrm{C}$ for 48 hours in both glass and plastic tubes (figures 7 and 8 ). The presence of hirudin inhibits the cold-promoted activation of factor VII in a dose dependent way. Total inhibition is only seen when the samples are incubated in plastic tubes. In the presence of glass there is a persistent activity that can be attributed to a thrombin independent cold-promoted activation caused by the contact phase of blood coagulation. The inhibition by hirudin of coldpromoted activation in plastic tubes indicates that thrombin is involved especially if contact activation is (negligibly) low. The mechanism by which thrombin activates factor VII cannot be derived from this experiment, of course. As could be expected no factor VII activation is observed when the experiments depicted in the figures 7 and 8 are carried out with factor XII deficient plasmas. In order to track down a possible effect of thrombin upon the contact phase of blood coagulation, we determined the kallikrein formation during incubation of normal pooled plasma at $4^{\circ} \mathrm{C}$ in glass and plastic tubes in the absence and presence of hirudin (Table 1). It is evident from Table 1 that the presence of hirudin in the incubation mixture does not influence the generation of kallikrein as measured with the chromogenic substrate S2302.

From the figures 9 and 10 it is evident that the presence of thrombin in the incubation mixture stimulates the cold-promoted activation of factor VII both in glass and plastic. 


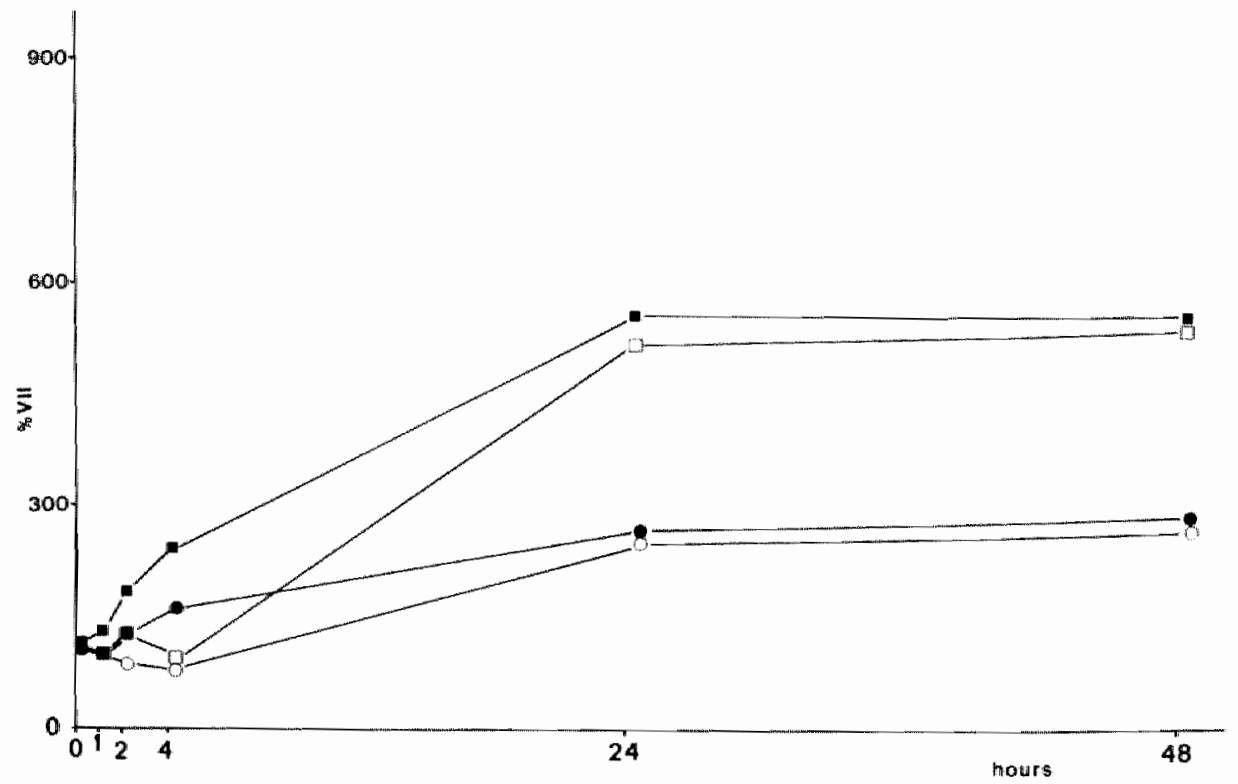

Figure 1. Activation of factor $\mathrm{VII}$ in normal plasma during incubation at $4^{\circ} \mathrm{C}$ in glass and plastic tubes as measured with bovine and human thromboplastin.

- glass; bovine thromboplastin

[-] plastic; bovine thromboplastin

- glass; human thromboplastin

O-O plastic; human thromboplastin 


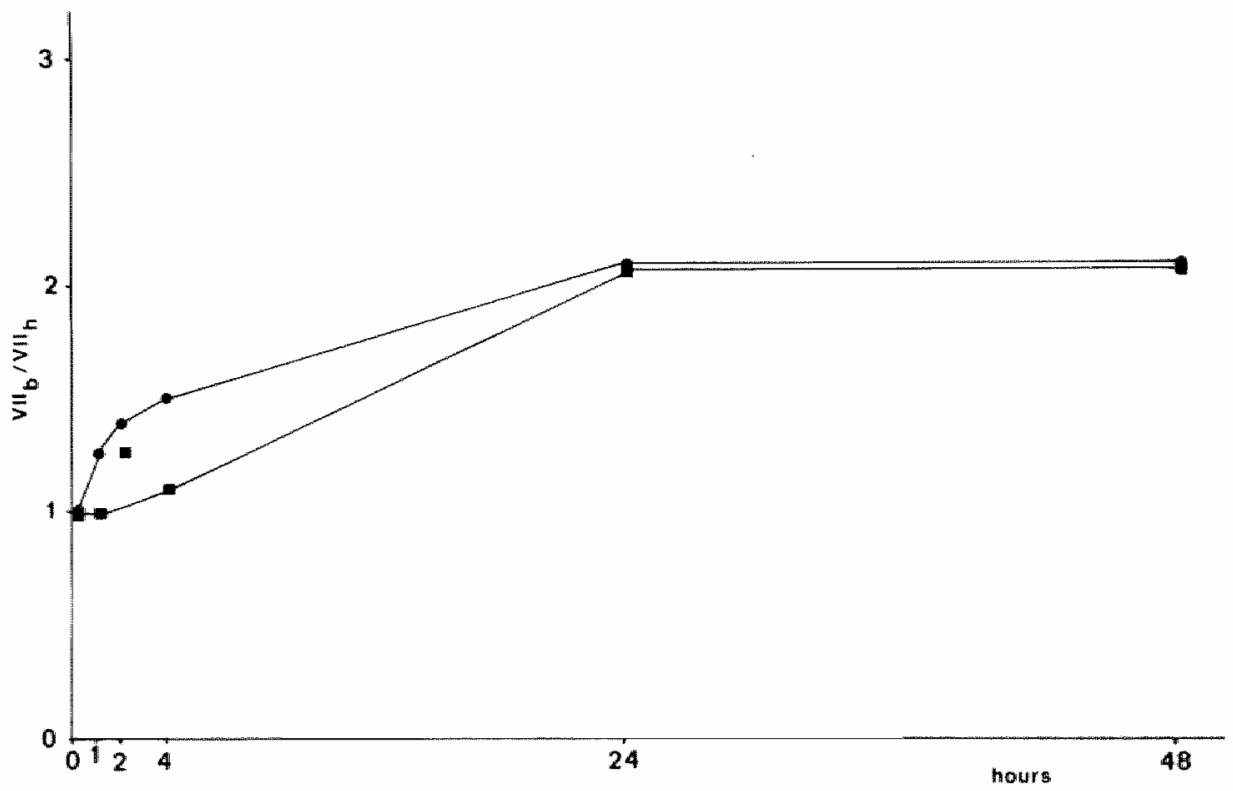

Figure 2. The ratio factor $V \|_{b} /$ factor $V \|_{h}$ in pooled normal plasma during incubation at $4^{\circ} \mathrm{C}$ in glass 10 ) and plastic ( 10 ) tubes.

53 


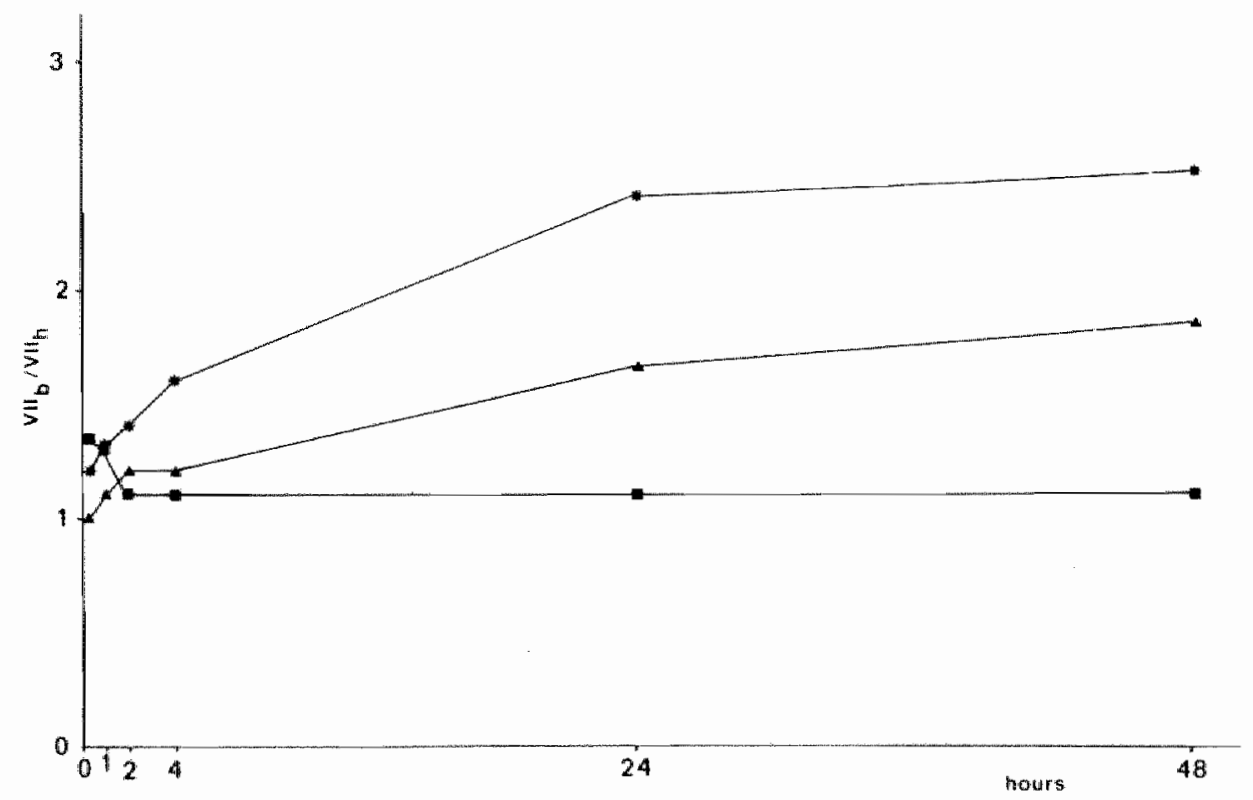

Figure 3. The ratio factor $\mathrm{V} / \mathrm{I}_{\mathrm{b}}$ / factor $\mathrm{V} \mathrm{H}_{\mathrm{h}}$ in congenital deficient plasma during incubation at $4^{\circ} \mathrm{C}$ in glass tubes

4. A factor V deficient plasma

W- factor VII deficient pllasma 


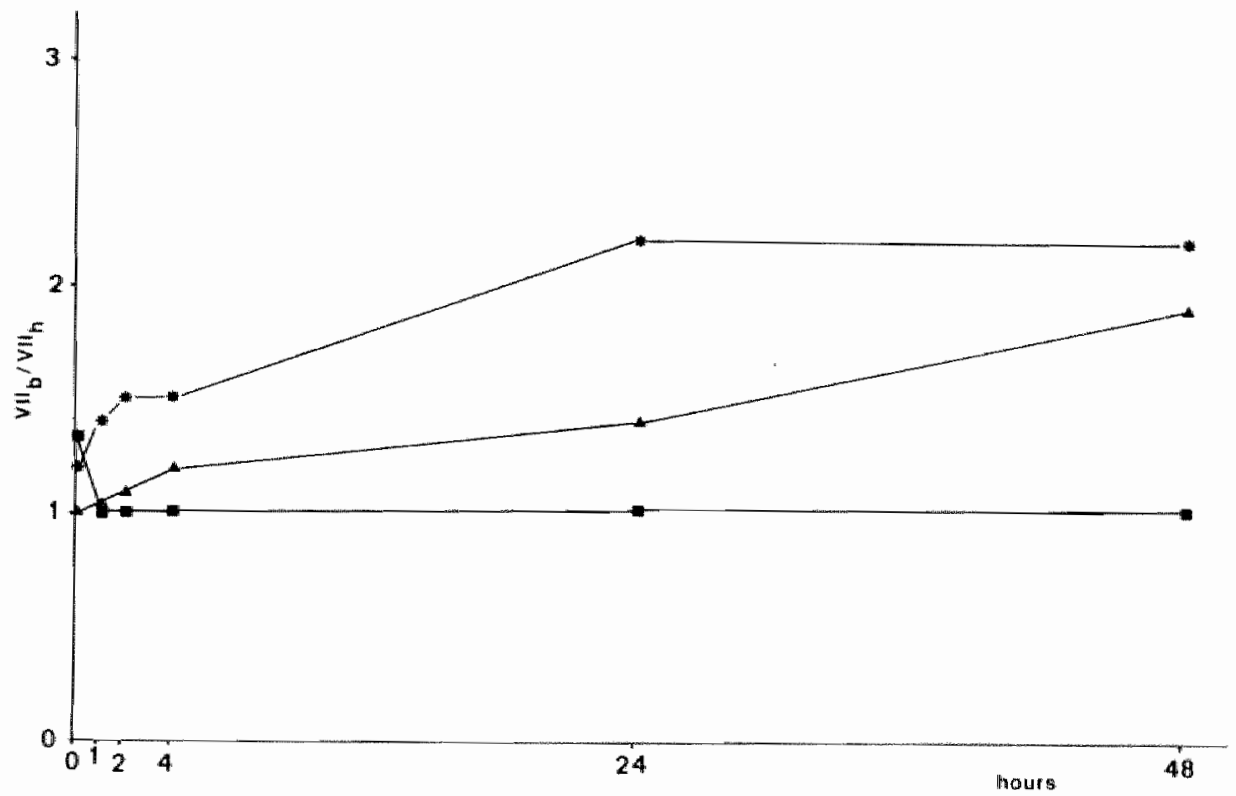

Flgure 4. The ratio factor $V I_{b}$ / factor $V I_{h}$ in congenital deficient plasma during incubation at $4^{\circ} \mathrm{C}$ in plastic tubes.

$\Delta-\Delta$ factor $V$ deficient plasma

-D factor VII deficient plasma

*-4 factor $x$ delicient plasma 


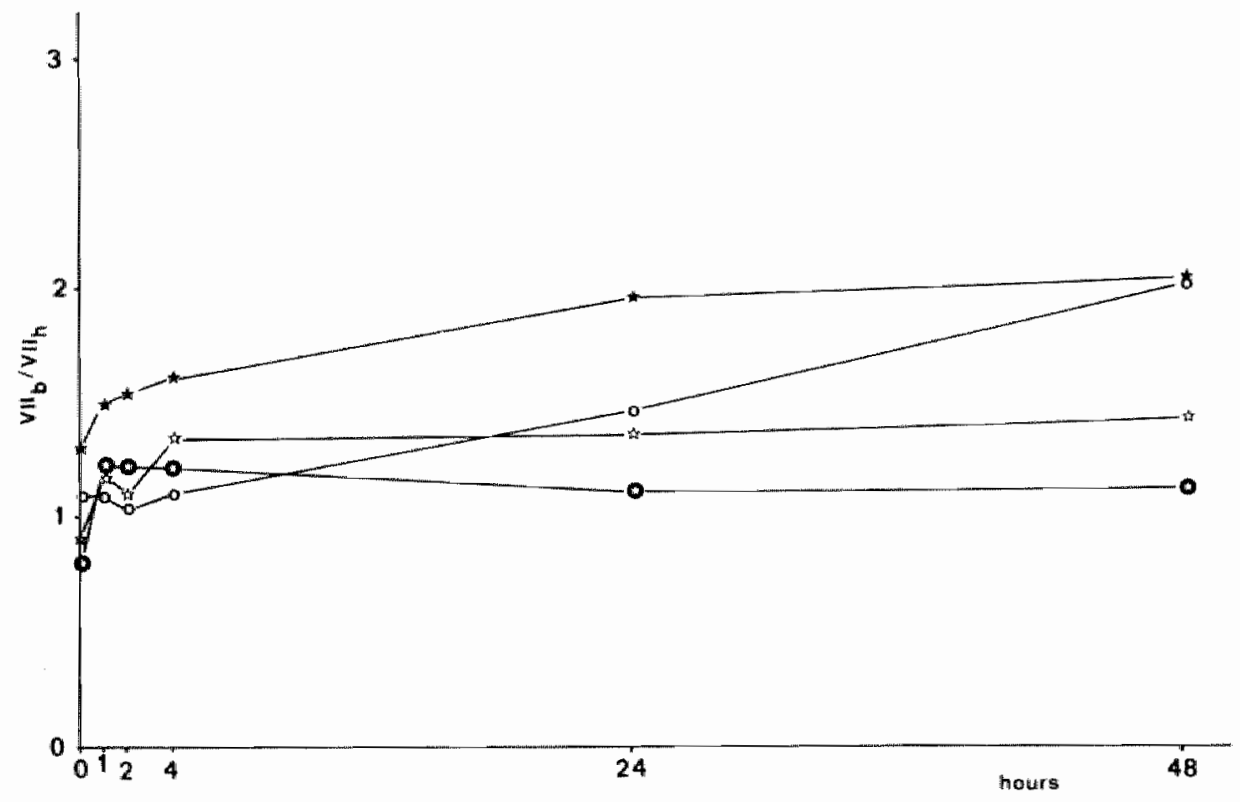

Figure 5. The ratio factor $V \|_{b} /$ factor $V I_{h}$ in congenital deficient plasma during incubation at $4^{\circ} \mathrm{C}$ in glass tubes.

O-O factor VIII deficient plasma

factor $I X$ deficient plasma

$\downarrow$ factor XI deficient plasma 


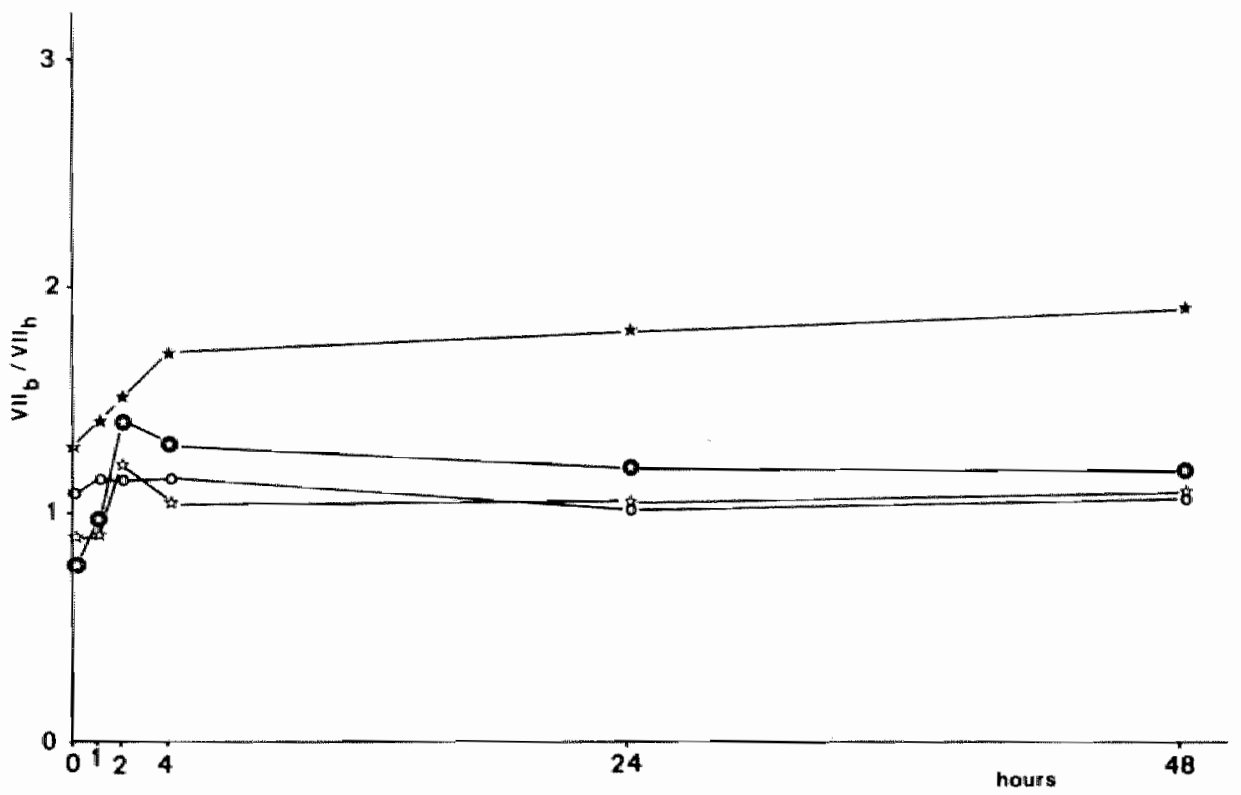

Figure 6. The ratio factor $\mathrm{VII}_{\mathrm{b}}$ / factor $\mathrm{V} \mathrm{H}_{h}$ in congenital deficient plasma during incubation at $4^{\circ} \mathrm{C}$ in plastic tubes.
- O factor VIII deficient plasma
\& $\$$ factor IX deficient plasma
$\downarrow$ factor XI deficient plasma
๑- $\$$ factor XII deficient plasma 


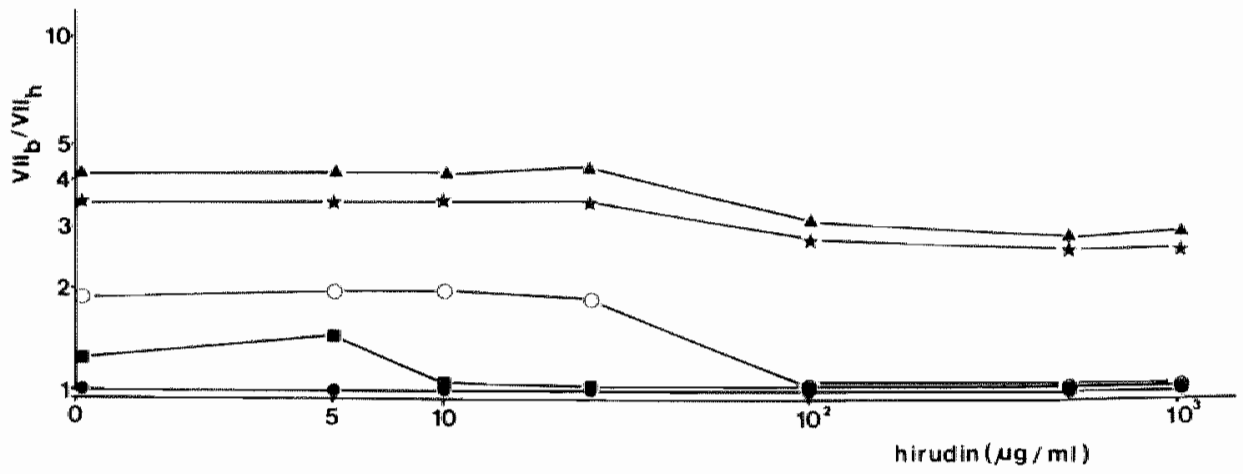

Figure 7. The ratio factor $\mathrm{VII}_{\mathrm{b}} /$ factor $\mathrm{VII} h$ in normal plasma incubated at $4^{\circ} \mathrm{C}$ in glass tubes in the presence of different hirudin concentrations. Incubation time:

$$
\begin{aligned}
& \text { - }=0 \text { hours } \\
& \text { D. }=2 \text { hours } \\
& \mathrm{O}-\mathrm{O}=4 \text { hours } \\
& \star \star=24 \text { hours }
\end{aligned}
$$




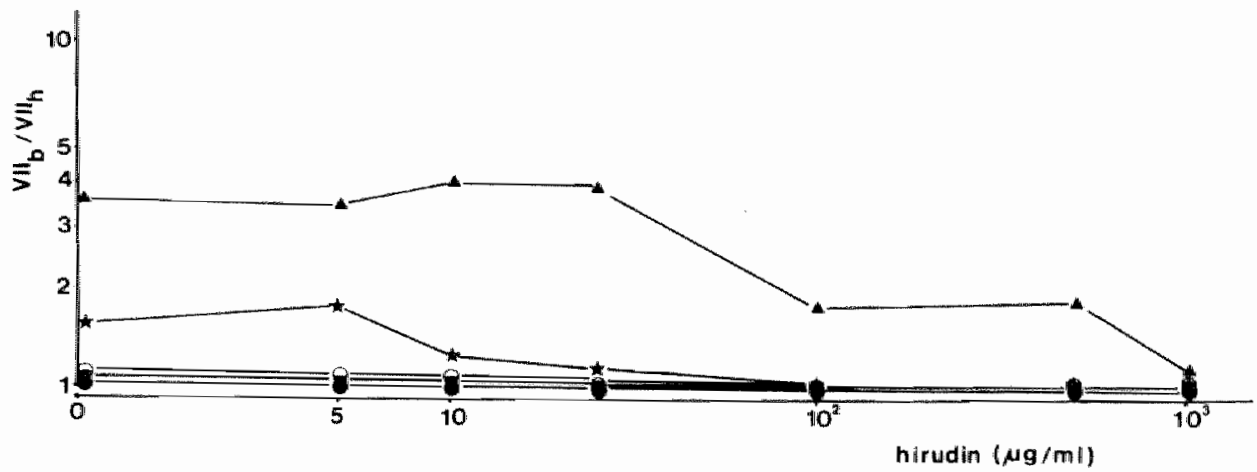

Figure 8. The ratio factor $\mathrm{V} / \mathrm{H}_{\mathrm{b}}$ / factor $\mathrm{V} / \mathrm{I}_{\mathrm{h}}$ in normal plasma incubated at $4 \mathrm{C}$ in plastic tubes in the presence of different hirudim concentrations. Incubation time:

$$
\begin{aligned}
& O=0 \text { hours } \\
& -O=2 \text { hours } \\
& O-O=4 \text { hours } \\
& +\Delta=24 \text { hours } \\
& \Delta-48 \text { hours }
\end{aligned}
$$




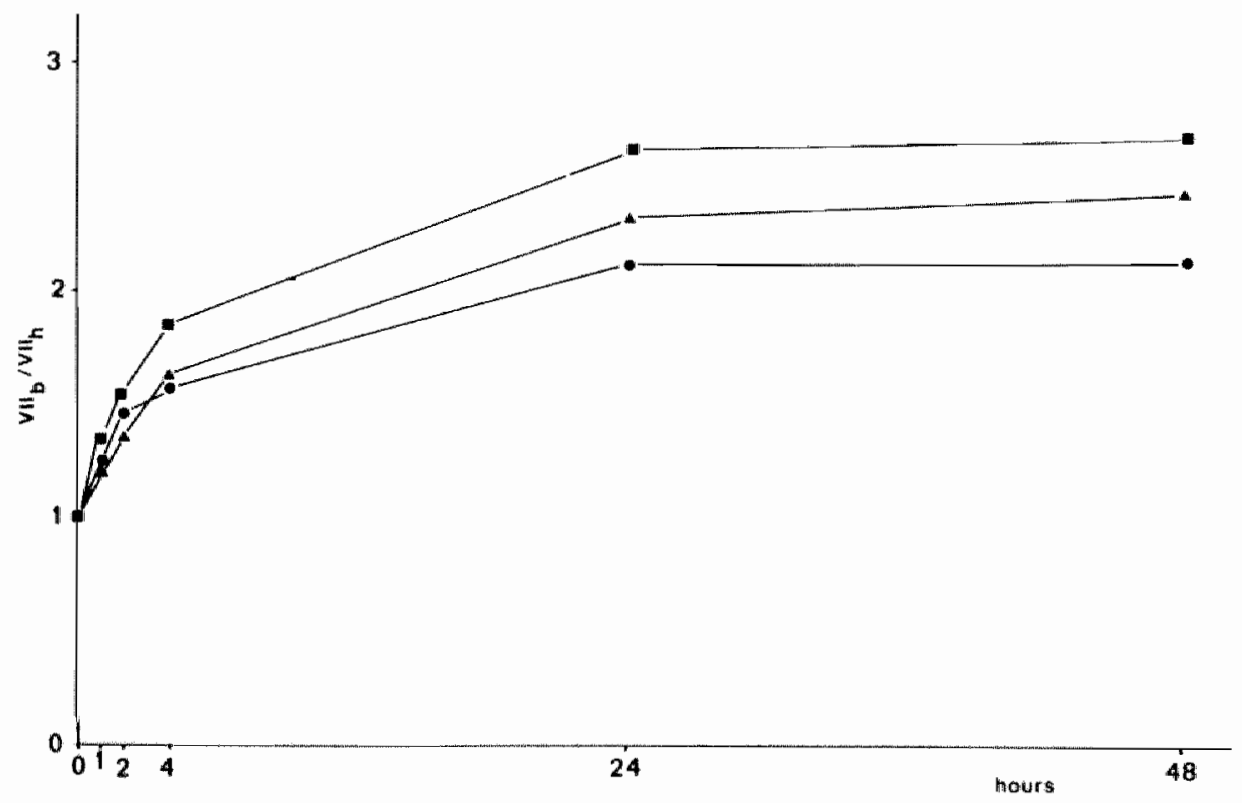

Figure 9. The ratio factor $\mathrm{VII} b /$ factor $\mathrm{Vll} h$ in normall plasma incubated at $4{ }^{\circ} \mathrm{C}$ in glass tubes in the presence of different thrombin concentrations.

- normal plasma

$\Delta{ }_{10}^{-3} \mathrm{U}$ thrombin/mI normal plasma

a- $10^{-2} \mathrm{U}$ thrombin/ml normal plasma 


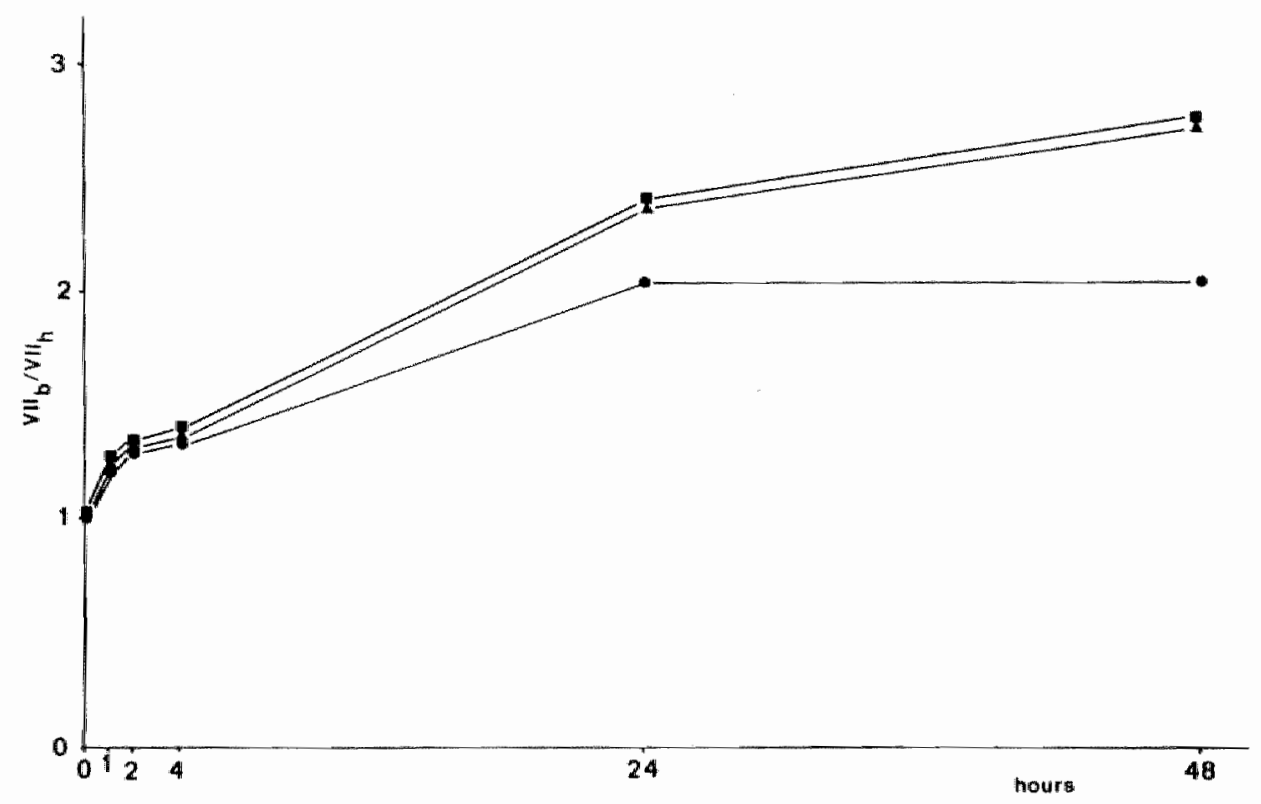

Figure 10 . The ratio factor $V \|_{b} /$ factor $V I_{h}$ in normal plasma incubated at $4^{\circ} \mathrm{C}$ in plastic tubes in the presence of different thrombin concentrations.

- normal plasma

$4.10^{-3}$ U thrombin/mil normal plasma

-1 $10^{-2}$ U thrombin/ml normal plasma 
The effect of hirudim on the generation of kallikrein activity during incubation of nomal plasma at $4 \% \mathrm{C}$.

incubate

composition velocity of 52302 hydrolysis

(0.1 arbitrary units/min.)

$\begin{array}{lll}\text { ohours } & 4 \text { hours } & 24 \text { hours } \\ \text { incubation } & \text { incubation } & \text { incubation }\end{array}$

buffer $(G, P)$

hirudin in buffer $(G, P)$

normal plasma + butter $(P)$

normal plasma + hirudin (P)

normal plasma + buffer $(G)$

normal plasma + hirudin (G)
$-$

$-$

$-$

$-$

$-$

(2)

\begin{tabular}{llll}
\hline buffer $(G, P)$ & - & - \\
hirudin in buffer $(G, P)$ & - & - \\
normal plasma + buffer $(P)$ & - & - & 0.1 \\
normal plasma + hirudin $(P)$ & - & - & 0.1 \\
normal plasma + buffer $(G)$ & - & 0.2 & 0.3 \\
normal plasma + hirudin $(G)$ & - & 0.2 & 0.3 \\
\hline
\end{tabular}

Normal plasma is incubated in the presence or absence of hirudin (final concentration $1000 \mu \mathrm{g} / \mathrm{mll}$; the kallkrein generation is measured with $\mathrm{S} 2302$.

G: incubation in glass;

P. incubation in plastic.

\section{Discussion}

The direct effect of contact activation on the extrinsic coagulation pathway was already described by Altman and Hemker who concluded that factor XIla activated factor VII (6). The involvement of both factor IX and factor XII in the activation of factor VII (figures 5 and 6$)$ has been described in the literature $(7,8,9,10,11,12)$. The role of kallikrein in the cold-promoted activation of factor VII would be indirect through the generation of factor XIla and factor IXa. Both Seligsohn et al and Palmer and Gralnick agree that factor IX appears to contribute to approximately $50 \%$ in the factor VII activation upon incubation at $4^{\circ} \mathrm{C}(9,10)$. Our results are in agreement with these findings.

The essential role of factor II in the cold-promoted activation of factor VIII (figures 3 and 4) has not been described before. The effect of factor II could be direct, as factor VII activation by thrombin has been described (15). By this mechanism trace amounts of thrombin formed could activate factor VII during the incubation at $4^{\circ} \mathrm{C}$. The role of factor II could also be indirect, for instance via an effect of trace amounts of thrombin on the contact phase of blood coagulation . 
In order to study the effect of factor II on the process of coldpromoted activation, factor II deficiency was approximated by adding the thrombin inhibitor hirudin to normal plasma. As can be seen in the figures 7 and 8 the addition of hirudin to the incubation mixture slows down the cold-promoted activation of factor VII in a dose dependent way, total inhibition does not occur when the incubation takes place in glass. We also tried to approximate factor II deficiency by adding a factor II specific antiserum to normal plasma. However, this factor II specific antiserum also contained small amounts of an inhibitory activity directed against the other clotting factors. Moreover factor II neutralization with a factor II specific antiserum requires an extra incubation step ( 30 minutes at $22^{\circ} \mathrm{C}$ ) possibly interfering with the process of cold-promoted factor VII activation. This problem can only be solved when a highly specific antibody directed against thrombin will be available. When, in parallel with factor VII activation, the activation of the contact phase of blood coagulation is followed by measurement of kallikrein generation with the chromogenic substrate $\mathrm{S} 2302$ (Table 1) it can be seen that the presence of hirudin does not influence the kallikrein generation. Therefore, the activation of the contact phase of blood coagulation by trace amounts of thrombin can be ruled out.

We conclude that the cold-promoted activation of factor VII is the result of at least two parallel processes:

1. an activation of factor VII by activated contact products (a process not inhibited by hirudin)

2. a direct activation of factor V/l by thrombin (a process inhibited by hirudin).

The former process explains the difference in the time course of colld-promoted activation of factor VII in glass and plastic tubes; contact activation is more pronounced on glass than on plastic surfaces. The latter process explains the effect of hirudin on the cold promoted activation of factor VII.

When plasmas of normal individuals are incubated at $4^{\circ} \mathrm{C}$ all samples show cold-promoted activation of factor VII upon incubation in glass; only $25 \%$ shows cold-promoted factor VII activation upon incubation in plastic (results not shown). These results can be explained by the contribution of the contact phase of blood coagulation. We wonder if we might speculate that 'cold activators' do occur because of the generation of (trace amounts of) thrombin in vivo.

To study the mechanism of cold-promoted activation, all congenital factor deficient plasmas were incubated in both glass and plastic.. 
The fact that several congenital factor deficient plasmas show more or less reduced cold-promoted activation of factor VII upon incubation in plastic whereas a normal factor VII activation is reached upon incubation in glass, most probably must be explained by an impaired thrombin gemeration in the former situation (in vivo or in vitro).

The involvement of factor II in the cold-promoted activation could also explain the results of Donaldson (16). This author describes that there is no clear relationship between $\mathrm{C}_{4}$-inhibitor deficiency and cold-enhanced plasma coagulation and suggests that events which initiate the process of cold-enhanced clotting activation in vitro have already occurred in vivo. The equilibria influencing this tendency vary among patients and possibly in any given patient in the course of time. This makes us think that it might be useful to investigate whether the cold promoted factor VII activation in vitro can be used as an early indicator of in vivo changes in the clotting system as a result of pathological processes. 
1. Meade T.W., North W.R.S., Chakrabarti R., Stirling Y., Haines A.P., Thompson S.G. Brozovic M. Haemostatic function and cardiovascular death: evarly results of a prospective study. Lancet i: 1050-1054, 1980.

2. Meade T.W. Factor WII and ischaemic heart disease: epidemiological evidence. Haemostasis 13: $178-185,1983$

3. van Delik W.A., van Dam-Mieras M.C.E., Muller A.D. Activation of factor VII in patients with carcinoma of the prostate. A prellminary report.

Haemostasis 13: 198-200, 1983.

4. Hemker H.C., Muller A.D., Gonggrijp R. The estimation of activated human blood coagulation factor VII. J Mol Med 1: 127-134, 1976.

5. Alving B.M., Tankersley D.L., Mason B.L. Plasma prekallikrein: quantitative determination by direct activation with Hageman factor fragments (factor Xlla). 4. Lab. Clin. Med' 101: 226-241, 1983 .

6. Altman R., Hemker H.C. Contact activation in the extrinsic blood clotting system. Thrombos. Diathes. Haemorth. 18: 523-531, 1967.

7. IKisiel W., Fujikawa K., Davie E.W. Activation of bovine factor VII (Proconvertin) by factor Xlla (Activated Hageman factor). Biochemistry 16:4189-4194 1977 .

8. Radcliffe R., Bagdasarian A., Colman R., Nemerson Y. Activation of bovine factor VII by Hageman factor fragments. Blood 50:61\%-617, 1977 .

9. Selligsohn U., Esterud B.,Griffin J.H., Rapaport S.I. Evidence for the participation of both activated factor XII and activated factor $X X$ in the cold-promoted activation of factor VII. Thromo. Res. 13: 1049-1056,1978.

10. Palmeir R.N., Gralnick H.R. Cold-induced contact surface activation of the prothrombin time in whole blood. Blood 59: 38-42, 1983.

11. Seligsohn U, O'sterud B., Brown S.F., Griffin J.H., Rapaport S.I. Activation of human factor VII in plasma and purified systems. J. Clin. Invest. 64: 1056-1065, 1979.

12. Gordon E.M., Ratnoff O.D., Jones P.K. The role of augmented Hageman factor (factor XIII titers in the cold-promoted activation of factor VII and spontaneous shortening of the prothrombin time in women using oral contraceptives.

J. Lab. Clin. Med. 99: 363-369, 1982.

13. Gjennaes H. Cold-promoted activation of factor VII. I. Evidence for the existence of an activator. Thrombos. Diathes. Haemorh. 28: 155-168, 1972.

14. Gjonnaes H. Cold-promoted activation of factor VII. III. Relation to the kallikrein system. Thrombos. Diathes. Haemorrh. 28: 182-193, 1972.

15. Radcilffe J.B.C., Nemerson $Y$. Actiwation and control of factor VIll by activated factor $X$ and thrombin. Isolation and characterization of a single chain form of factor VII. J. Biol. Chem. 250: 388-395, 1975.

16. Donaldson V.H. Cold enhancement of blood coagulation: observations on the role of C 1 inhibitor.

Acta Pathol, and Microbiol Scand. Section G: Immunology Suppl. 284, 92:41-47, 1984. 

Blood coagulation parameters in cancer patients, with emphasis on factor VIla and factor Xa

\section{Introduction}

A large number of blood coagulation parameters has been studied in patients with all kinds of malignant disease. The results of these studies in patients with solid tumors vary from abnormalities in almost all patients to hardly any abnormality at all $(1,2$, see also chapter I). In none of the studies a correlation between the degree of the abnormalities found and the state of disease could be established, except for one parameter $(3,4)$. This parameter was plasma fibrinopeptide $A$ (FPA). It was reported to be elevated in plasma in $60-95 \%$ of patients with cancer $(3,5)$. In one study of lung cancer it tended to increase during, or rather just before, clinical disease progression (6). However, more recent studies revealed that the method used by Peuscher et al not only measured plasma FPA, but also a variety of other fibrin(ogen) fragments containing the FPA moiety. With a more specific FPA determination, developed in the same laboratory, abnormal levels in the plasma of cancer patients could only be found in $6 \%$ instead of the $60 \%$ with the method described by Peuscher et al $(3,7)$.

Despite in vitro experiments revealing activation of factor $\mathrm{VII}$ and/or factor $X$ by tumor cells and/or tumor related macrophages in various models $(8,9,10,11,12)$, no systematic study of the activation of blood coagulation factors in patients with cancer has been carried out. A pilot study of activated factor VII in plasma of patients with benign and malignant disease of the prostate encouraged us to carry out a prospective study to blood coagulation parameters in patients with and without metastatic breast, renal and prostatic cancer, with emphasis on factor VIla and factor $\mathrm{Xa}$ (13). We also investigated if there was a correlation between the change in the blood coagulation parameters and the occurrence of progressive disease in an individual patient during long-term follow-up. Finally, we estimated the blood coagulation parameters in relation to the extent of disease. 


\section{Patients and Methods}

\section{Patients}

From 1981 to 1984106 patients with cancer were studied, 53 female and 53 male. Fourty-six patients had breast cancer, 25 had renal cell carcinoma and 35 had prostatic carcinoma. Of these patients 57 had no clinical evidence of manifest tumor growth. To this group three additional patients were added, who had complete remissions with hormonal treatment. Fourty-six patients had clinical metastatic disease. Values of factor VII, factor VIlla and antithrombin III (AT III) were omitted in two patients using estrogens because of prostatic carcinoma and in one patient with renal carcinoma using estrogens because of postmenopausal complaints. AT III was omitted in two other patients using tamoxifen.

Table I and Table II show the clinical characteristics of the patients with metastatic disease.

Tablle I

Patient characteristics concerning the dominant site of disease in relation to the type of the primary tumor.

No patient had liver metastases.

\begin{tabular}{lccccc} 
& local & bone & lung & soft tissue & No of patients \\
\hline breast & - & 9 & 5 & 12 & 26 \\
prostate & - & 11 & - & 2 & 13 \\
kidney & 4 & - & 1 & 2 & 7 \\
all patients & 4 & 20 & 6 & 16 & 46 \\
\hline
\end{tabular}

\section{Table II}

Patient characteristics concerning the number of metastatic sites of disease, in relation to the primary tumor. Local recurrence, metastatic tumor localisations in Hung, bone and soft tissue were considered to be different sites of disease.

\begin{tabular}{lcccc}
\hline & 1 & 2 & $\geqslant 3$ & No of patients \\
\hline breast & 14 & 9 & 3 & 26 \\
prostate & 8 & 4 & 1 & 13 \\
kidney & 1 & 6 & - & 7 \\
all patients & 23 & 19 & 4 & 46 \\
\hline
\end{tabular}


Tumor spread was determined by physical examination, appropriate laboratory tests, radiographs and radionuclide scans. Patients were considered disease free when all such evaluation failed to show evidence of residual primary, recurrent or metastatic disease after local therapy. Local disease was defined as a progressive tumor mass at the site of the primary tumor. For the presence of liver metastases at least a pathologic ultrasound or CT-scan was required. Lung metastases were based upon abnormal chest films. Bone metastases required evidence of an osteolytic/osteoblastic process by $X$-ray films or a positive Technetium bone scan. Soft tissue metastases were determined by palpation or imaging techniques. Most patients were followed longitudinally for periods varying from 6 to 39 months.

Methods

I. Laboratory tests

Factor VII was determined by the one stage clotting test described in chapter III.

Factor VIla was determined by the ratio:

factor VII determined with bovine thromboplastin

factor VII determined with human thromboplastin described in chapter III as well.

Factor $X$ and factor $X$ a were measured with an automated chromogenic substrate assay according to Bas et al (14). The reagent solution of the factor $X$ assay contained a mixture of one volume of Russell's Viper Venom (RVV, $1 \mathrm{mg}$ lyophilized factor $X$ activating protein in $0.1 \mathrm{mmol} / \mathrm{l}$ sodium chloride, dissolved in $15 \mathrm{ml}$ distilled water), one volume $\mathrm{CaCl}_{2} 0.1 \mathrm{~mol} / \mathrm{l}$, two volumes $\mathrm{S} 2337$ solution ( $30 \mu$ mol lyophilized S 2337 dissolved in $20 \mathrm{ml}$ distilled water) (Kabi Vitrum, Amsterdam) and one volume of Tris buffer $(0.05 \mathrm{~mol} / \mathrm{l}, 20 \mathrm{mg} / / \mathrm{l}$ polybrene, $\mathrm{pH} 7.8)$. In the reagent solution of factor $\mathrm{Xa}$, the RW-solution needed to activate factor $\mathrm{X}$, was replaced by one volume of distilled water.

Antithrombin III (AT III) was determined by the method according to Bas et al (14). The start reagent contained chromogenic substrate $S$ 2238, polybrene and mannitol (Kabi Vitrum, Amsterdam), dissolved in distilled water, resulting in a chromogenic substrate concentration of $0.75 \mathrm{mmol} / \mathrm{l}$. The reagent solution contained $53 \mathrm{nKat}$ lyophilized bovine thrombin dissolved in $1.5 \mathrm{ml}$ distilled water and $75 \mathrm{ml}$ heparin buffer containing Tris $62.5 \mathrm{mmol} / \mathrm{l}$, EDTA $9.4 \mathrm{mmol} / \mathrm{l}$, heparin $3.75 \mathrm{IU} / \mathrm{ml}$ and $1.25 \%$ polyethyleneglycol $8000, \mathrm{pH} 8.4$.

Alpha-2-antiplasmin was determined according to Bas et al (14). The start solution contained $35 \mu \mathrm{mol}$ lyophilized chromogenic substrate S 2251 dissolved in $10 \mathrm{ml}$ distilled water and $22 \mathrm{nKat}$ 
lyophilized human plasmin dissolved in $10 \mathrm{ml}$ sterile glycerol and $\mathrm{HCl} 2 \mathrm{mmol} / \|(\mathrm{v} / \mathrm{v})$. The reagent solution contained one volume of the $\mathrm{S} 2251$ start solution and two volumes Tris buffer $(0.05 \mathrm{~mol} / \mathrm{l}, \mathrm{pH}$ 7.4).

Fibrin(ogen) degradation products were determined by the method of Haverkate et al (15).

Alkaline phosphatase was measured by standard methods. Normal values: $30-125 \mathrm{U} / 1$.

Acid phosphatase was measured by the method of Babson which has a high specificity for prostatic acid phosphatase (16). Normal values: $0-2.5 \mathrm{U} / 1$.

II Sampling procedure

Sampling was carried out as described in chapter III except that plasma was stored at $-80^{\circ} \mathrm{C}$ until testing.

Patient samples were obtained every 3 months between 9.00 and $11.00 \mathrm{hrs}$ a.m. by venipunctures. Only three well instructed assistents carried out the sampling during the follow-up period.

III Statistical analysis

To detect significant differences in laboratory determinations between patient groups the Mann-Whitney-Wilcoxon rank sum test was used, because the test was appropriate for all values (17). For illustrative reasons mean values $\pm S D$ instead of median values are given except for factor $X$, because the values were not normally distributed about the mean.

\section{Results}

1. Abnormal blood coagulation parameters (Table III)

In contrast with our preliminary findings (13) only one out of 12 patients with metastatic prostatic cancer had an increased plasma factor VIlla level. Of all patients with metastatic cancer, only 2 out of 45 had increased factor VIla levels. Six out of 45 patients had increased factor VII levels, and 5 out of 46 had increased factor $X$ levels. However, 16 out of 46 patients with metastatic cancer had increased plasma factor Xa levels.

2. Plasma levels of the coagulation parameters of patients with and without manifest metastatic disease (Table ( $V$ and $V$ )

As shown in Table IV no significant differences could be found between the values of both patient groups, nor between the patient groups and normal controls. However, with analysis by tumor type, factor Xa levels of breast cancer patients with metastatic disease appeared to be significantly higher than those of patients without 
Tablle III

Number of patients with metastatic cancer with increased rspectively decreased values of different coagulation parameters.

Normal values are given in Table IV.

\begin{tabular}{lllllll}
\hline & & $f$ VII & $f$ VIla & $f \times$ & $f \times a$ & AT III \\
\hline prostate & increased & $3 / 12$ & $1 / 12$ & $1 / 13$ & $4 / 13$ & $0 / 12$ \\
& decreased & $0 / 12$ & $2 / 12$ & $0 / 13$ & - & $0 / 12$ \\
kidney & increased & $0 / 7$ & $0 / 7$ & $0 / 7$ & $2 / 7$ & $1 / 7$ \\
& decreased & $0 / 7$ & $2 / 7$ & $0 / 7$ & - & $0 / 7$ \\
breast & increased & $3 / 26$ & $1 / 26$ & $4 / 26$ & $10 / 26$ & $0 / 26$ \\
& decreased & $1 / 26$ & $0 / 26$ & $0 / 26$ & - & $0 / 26$ \\
\multirow{3}{*}{ all patients } & increased & $6 / 45$ & $2 / 45$ & $5 / 46$ & $16 / 46$ & $1 / 45$ \\
& decreased & $1 / 45$ & $4 / 45$ & $0 / 46$ & - & $0 / 45$ \\
\hline
\end{tabular}

\section{Table IV}

Mean plasma levels \pm SD of bioad coagulation parameters of all patients with cancer with and without clinical evidence of metastases. For factor $X a$ only the median values are shown as the plasma levels were not normally distributed about the mean. The number of patients varies because values of patients on hormonal treatment were omitted (see text).

\begin{tabular}{|c|c|c|c|c|c|c|}
\hline & metastases & $\%$ I VII & I Villa & $\% \neq x$ & $\%$ & $\%$ ATIII \\
\hline all cancer patients & $\begin{array}{l}\text { yes } \\
\text { no }\end{array}$ & $\begin{array}{c}98.8 \pm 25.8 \\
(n=45) \\
107.7 \pm 27.7 \\
(n=58)\end{array}$ & $\left(\begin{array}{c}0.96 \pm 0.23 \\
(n=45) \\
0.98 \pm 0.24 \\
(n=58)\end{array}\right.$ & $\begin{array}{c}110.0 \pm 24.6 \\
(n=46) \\
106.0 \pm 20.2 \\
(n=60)\end{array}$ & $\begin{array}{c}4.0 \\
(n=46) \\
2.5 \\
(n=60)\end{array}$ & $\begin{array}{c}102.5 \pm 12.9 \\
(n=45) \\
104.1 \pm 16.8 \\
(n=56)\end{array}$ \\
\hline normal controls & $\begin{array}{l}\text { mean } \pm S D \\
\text { normal val. }\end{array}$ & $\begin{array}{c}92.0 \pm 18.6 \\
55-129 \\
(n=34)\end{array}$ & $\begin{array}{c}1.01 \pm 0.2 \\
0.61-1.41 \\
(n=34)\end{array}$ & $\begin{array}{c}102.4 \pm 20.9 \\
61=144 \\
(n=63)\end{array}$ & $<5$ & $\begin{array}{c}104.3 \pm 13.4 \\
77-131 \\
(n=63)\end{array}$ \\
\hline
\end{tabular}

manifest metastases (Table $\mathrm{V}$ ). In this breast cancer patient population the sensitivity of increased factor Xa levels for the presence of metastases was $61 \%$, the specificity $90 \%$. Increased factor Xa levels also existed in some patients with prostatic and renal carcinoma, without manifest tumor growth. As the increased plasma factor Xa levels in these patients did not herald the occurrence of metastatic disease, probably other disease states occurring in this elderly patient group might contribute to the elevated factor Xa levels.

The only other significant difference in coagulation parameters appeared to be the lower plasma factor VII levels, although within 
the normal range, in renal carcinoma patients with compared to without metastases, probably reflecting a slight degree of increased intravascular coagulation.

\section{Table V}

Mean plasma levels \pm SD of blood coagulation parameters of patients with and without evidence of metastases, related to the type of cancer.

See further text of Table $N$.

\begin{tabular}{|c|c|c|c|c|c|c|}
\hline & metastases & of $f$ & f vila & \& $x$ & 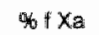 & \% ATIII \\
\hline \multirow[t]{4}{*}{ prostatic cancer } & yes. & $107.2 \pm 24.4$ & $1.00 \pm 0.28$ & $1068 \pm 27.0$ & 4.0 & $104.9 \pm 12.9$ \\
\hline & & $(n=12)$ & $(n=12)$ & $(m=13)$ & $(n=13)$ & $(n=12)$ \\
\hline & no & $106.2 \pm 35.5$ & $1.02 \pm 0.26$ & $106.8 \pm 18.3$ & 50 & $99.1 \pm 16.6$ \\
\hline & & $(n=21)$ & $(n=21)$ & $(n=22)$ & $(n=22)$ & $(n=21)$ \\
\hline \multirow[t]{4}{*}{ renal cancer } & yes & $89.3 \pm 2.2 .4$ & $0.83 \pm 0.18$ & $104.6 \pm 15.6$ & 0 & $107.3 \pm 20.0$ \\
\hline & & $(n=7)$ & $(n=\pi)$ & $n=7)$ & $(n=7)$ & $(n=7)$ \\
\hline & no & $117.4 \pm 21.5^{n+4}$ & $0.87 \pm 0.24$ & $105.8 \pm 25.1$ & 3.0 & $108.7 \pm 18.3$ \\
\hline & & $(n=17)$ & $(n=17)$ & $(n=18)$ & $(n=18)$ & $(n=17)$ \\
\hline \multirow[t]{4}{*}{ breast cancer } & yes & $97.4=27.0$ & $0.99 \pm 0.20$ & $113.5 \pm 25.6$ & $4.0^{\circ}$ & $100.1 \pm 10.4$ \\
\hline & & $(n=26)$ & $(n=26)$ & $(m=26)$ & $(n=26)$ & $(n=26)$ \\
\hline & no & $101,0 \pm 21.1$ & $1.04 \pm 0.19$ & $103.5 \pm 18.9$ & $2.0^{*}$ & $105.4 \pm 15.5$ \\
\hline & & $(n=20)$ & $(n=20)$ & $(n=20)$ & $(n=20)$ & $(n=18)$ \\
\hline
\end{tabular}

${ }^{*} p=0.008$

$m p=0.017$

3. Blood coagulation parameters during longitudinal follow-up of individual patients developing metastatic disease (figures 1 to 5) During longitudinal follow-up disease progression could be adequately established in 13 patients. Six patients had breast cancer, five prostatic cancer and two renal cancer. Statistical analyses were carried out to compare the blood coagulation parameters in plasma sampled 3 to 9 months before progression and 3 months before to 3 months after disease progression. No significant differences could be found (figures 1 and 2). Examples of individual cases (figures $3,4,5$ ) illustrate the absence of changes in the blood coagulation parameters during disease progression for the whole group of patients. In a patient with prostatic carcinoma the coagulation factors $\mathrm{VII}, \mathrm{VII}, \mathrm{X}$ and $\mathrm{Xa}$ did not show any relation to progression of disease (figures 3 and 4). This relation was also absent in a patient with progressive renal carcinoma (figure 5). Furthermore, two disease free patients developed a second primary tumor during follow-up (small cell lung cancer, colon carcinoma). Retrospectively, none of these two new tumors could have been predicted by changes in the blood coagulation parameters. 
4. Relation between the number of sites of disease and plasma levels of blood coagulation parameters (Table Vi)

The number of metastatic sites of disease can roughly be taken for the tumor load in a patient. It was our hypothesis that more sites of disease would coincide with increased alterations in blood coagulation parameters, especially factor Vlla and Xa. However, Table VI shows that factor VIlla and factor Xa levels in patients with

2 sites of disease were not significantly different from those patients with only one site of disease. Only AT IIIl levels were significantly lower in patients with 2 sites of disease in the absence of liver metastases, although all levels were within normal limits.

5. Fibrin(ogen) degradation products (FDP's) and alpha-2-antiplasmin

FDP's were studied in 6 patients with progressive disease during longitudinal follow-up. Although in one patient FDP's tended to rise during tumor progression, this was not so in the other 5 patients studied. Alpha-2-antiplasmin was determined in the plasma of 78 patients with cancer, but no significant decrease could be shown in patients with metastatic disease compared with patients without metastases (mean values 105.2\% $\pm 14.0, n=21$, versus $104.8 \%$ $\pm 14.0, n=57$, respectively, normal values: $67.5-135.9 \%$ ).

\section{Table VI}

Mean plasma levels $\pm S D$ of blood coagulation parameters of patients with metastatic cancer, related to the number of sites of disease.

See further text of Table IV.

\begin{tabular}{|c|c|c|c|c|c|}
\hline No. of sites & $\%+V I I$ & f Wlla & of $\mathrm{x}$ & $\%+x a$ & AT ATII \\
\hline 1 & $\begin{array}{c}97.8 \pm 23.5 \\
(n=22)\end{array}$ & $\begin{array}{c}0.97 \pm 0.32 \\
(n=22)\end{array}$ & $\begin{array}{c}113.2 \pm 25.7 \\
(n=23)\end{array}$ & $\begin{array}{c}4.0 \\
(n=23)\end{array}$ & $\begin{array}{c}106.9 \pm 11.1^{*} \\
(n=22)\end{array}$ \\
\hline $\begin{array}{c}2 \\
(n=19)\end{array}$ & $100.5 \pm 27.0$ & $0.91 \pm 0.21$ & $104.0 \pm 23.3$ & 3.0 & $98.5 \pm 12.6^{\circ}$ \\
\hline $\begin{array}{c}\geqslant 3 \\
(n=4)\end{array}$ & $95.8 \pm 38.3$ & $0.98 \pm 0.10$ & $121.0 \pm 20.6$ & 9.0 & 97.518 .5 \\
\hline
\end{tabular}

$* \mathrm{p}=0.026$ 


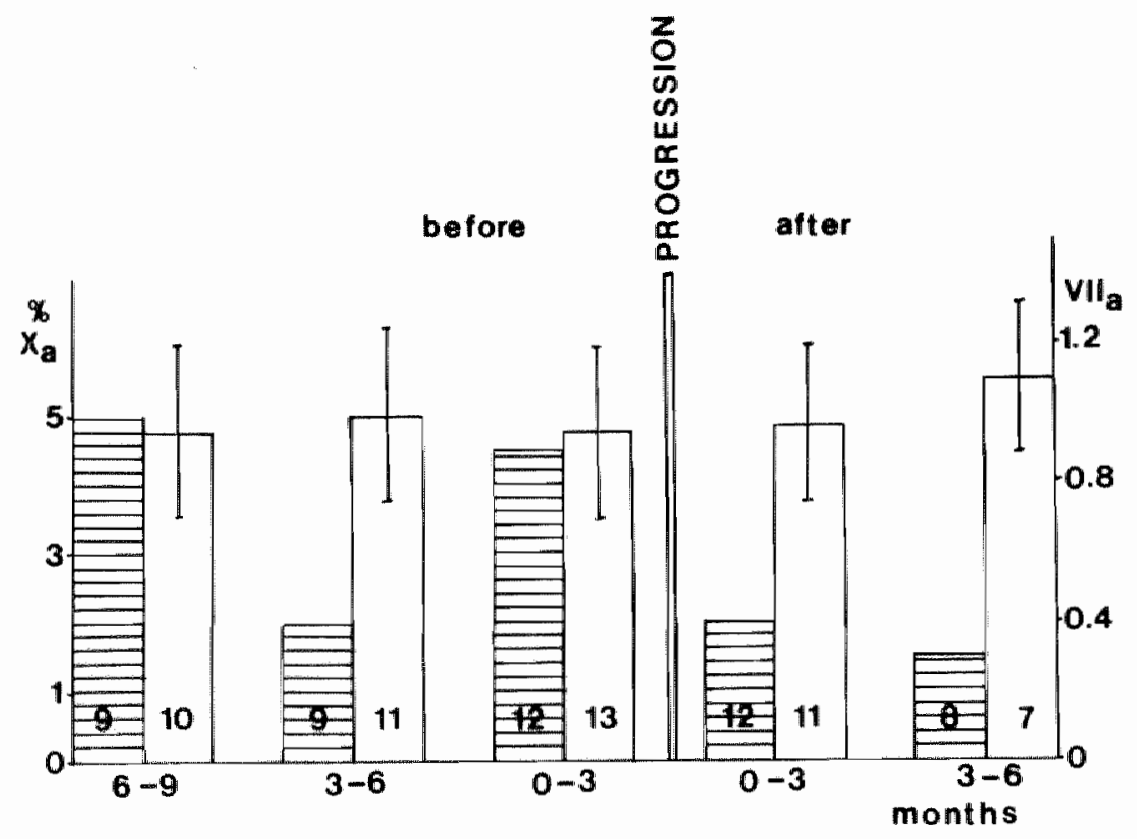

Figure 1. Plasma factors Vila and Xa levels obtained from cancer patients in periods of three months before and after the occurrence of clinical disease progression.

The hatched bar represents factor $X a$, expressed as a median value only, because the plasma lewels were not normally distributed about the mean. The white bar shows factor VIla as mean values $\pm 1 \mathrm{SD}$. The numbers in the bars indicate the number of patients studiled. 


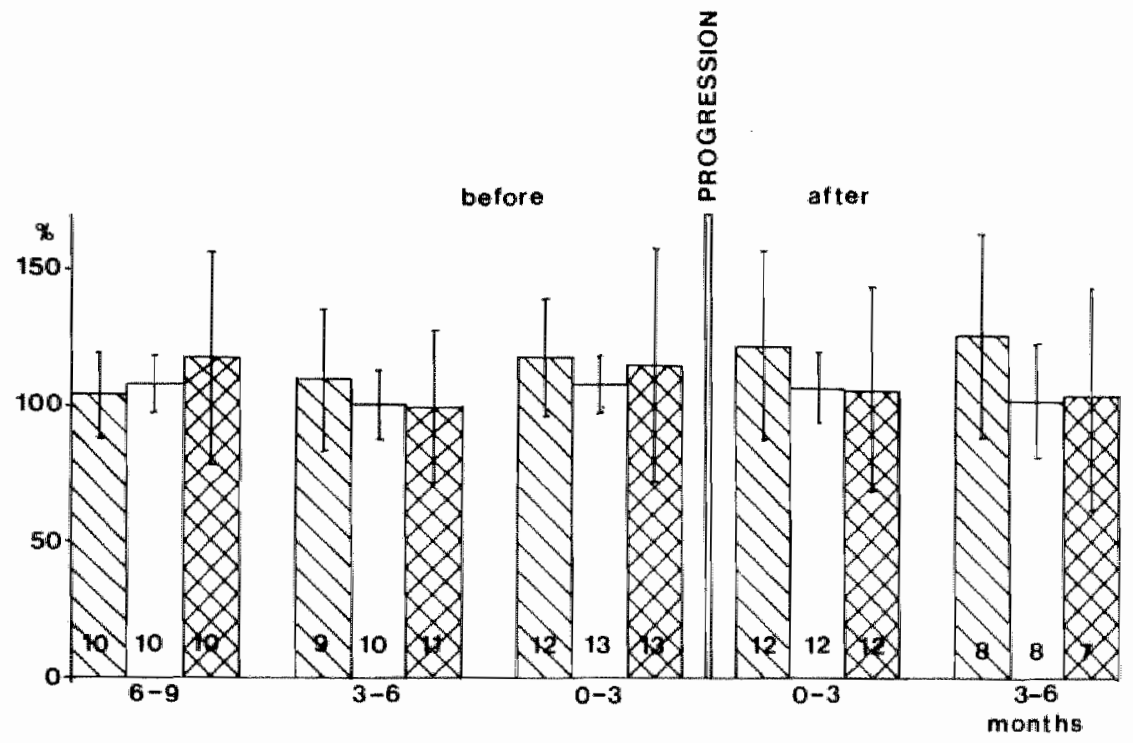

Figure 2. Plasma factor VII, factor $X$ and AT lll obtained in the same periods as indicated in figure 1 . The hatched bar represents factor $X$, the cross hatched bar factor VIl and the white bar AT III. All values are expressed in mean values $\pm 1 \mathrm{SD}$. 


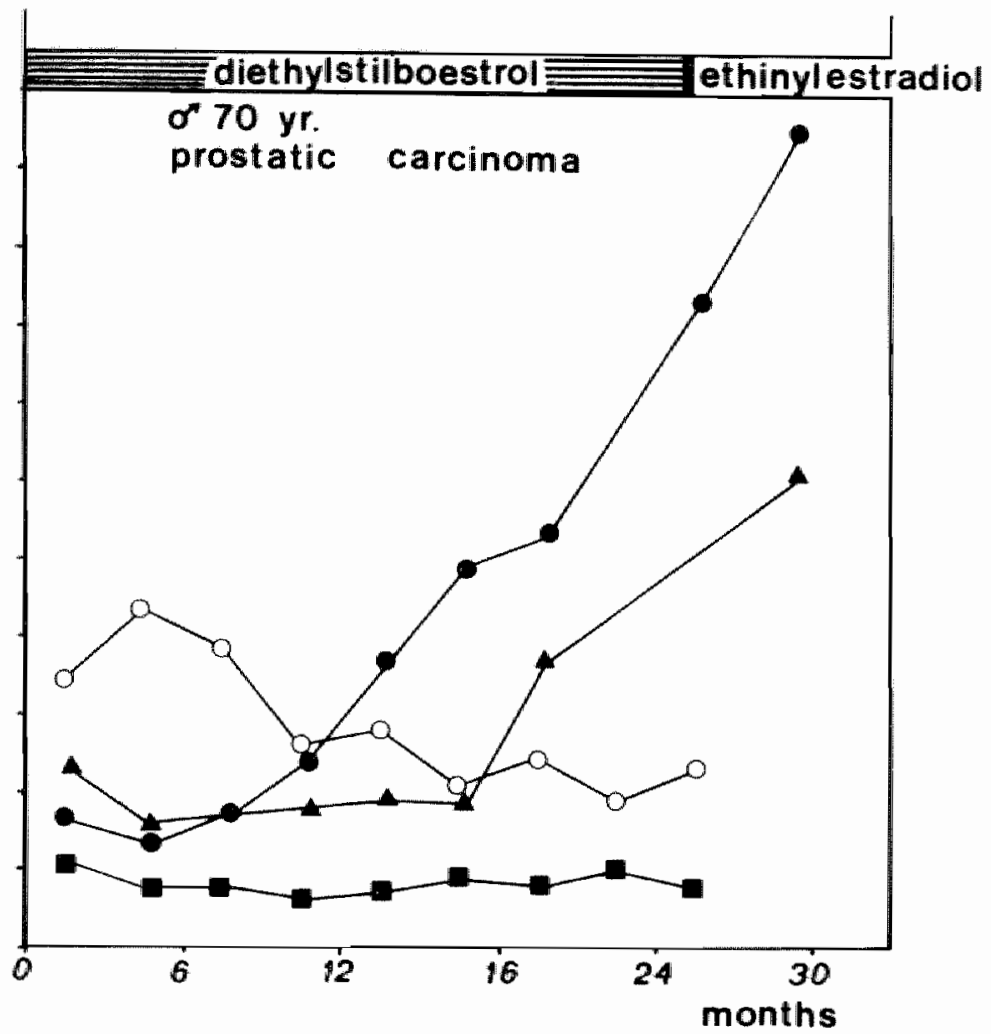

Figure 3. Plasma factor VII and VIla levels during longitudinal follow-up in a patient with progressive metastatic prostatic carcinoma. Progression is indicated by increasing serum levels of alk phosphatase and acid phosphatase.

The abscissa gives arbitrary units (a.u.).

- : alk.phosphatase $\quad(1$ a.u. $=50 \mathrm{U} / \mathrm{l})$

$\boldsymbol{\Delta} \mathbf{\Delta}$ : acid phosphatase $(1$ a.u. $=1 \mathrm{U} / \mathrm{l})$

O : factor VII (1 a.u $=50 \%)$

1 1 :factor VIla $\quad(1$ a.u. $=1)$ 


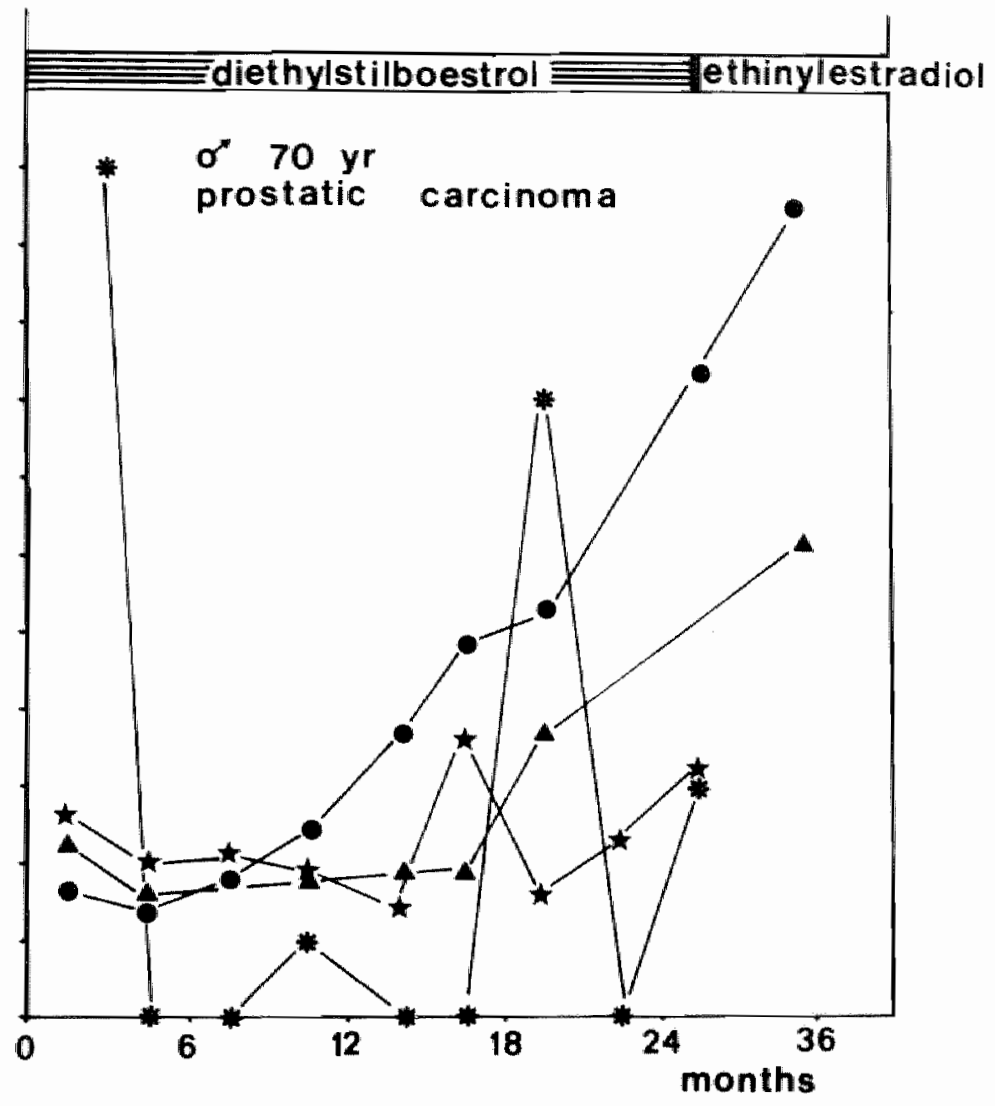

Figure 4. Plasma factor $X$ and $X a$ levels in the same patient as in figure 3 .

The abscissa gives arbitrary units (a.u.).
- : alk.phosphatase (1 a.u. $=50 \mathrm{U} / \mathrm{l})$
$\Delta-\mathbf{\Delta}$ : acid phosphatase $(1$ a.u. $=1 \mathrm{U} / \mathrm{l})$
$\star$ - $\downarrow$ : factor $X$
(1 a.u. $=50 \%$ )
* * : factor $x a$
$(11$ a.u. $=1 \%)$ 


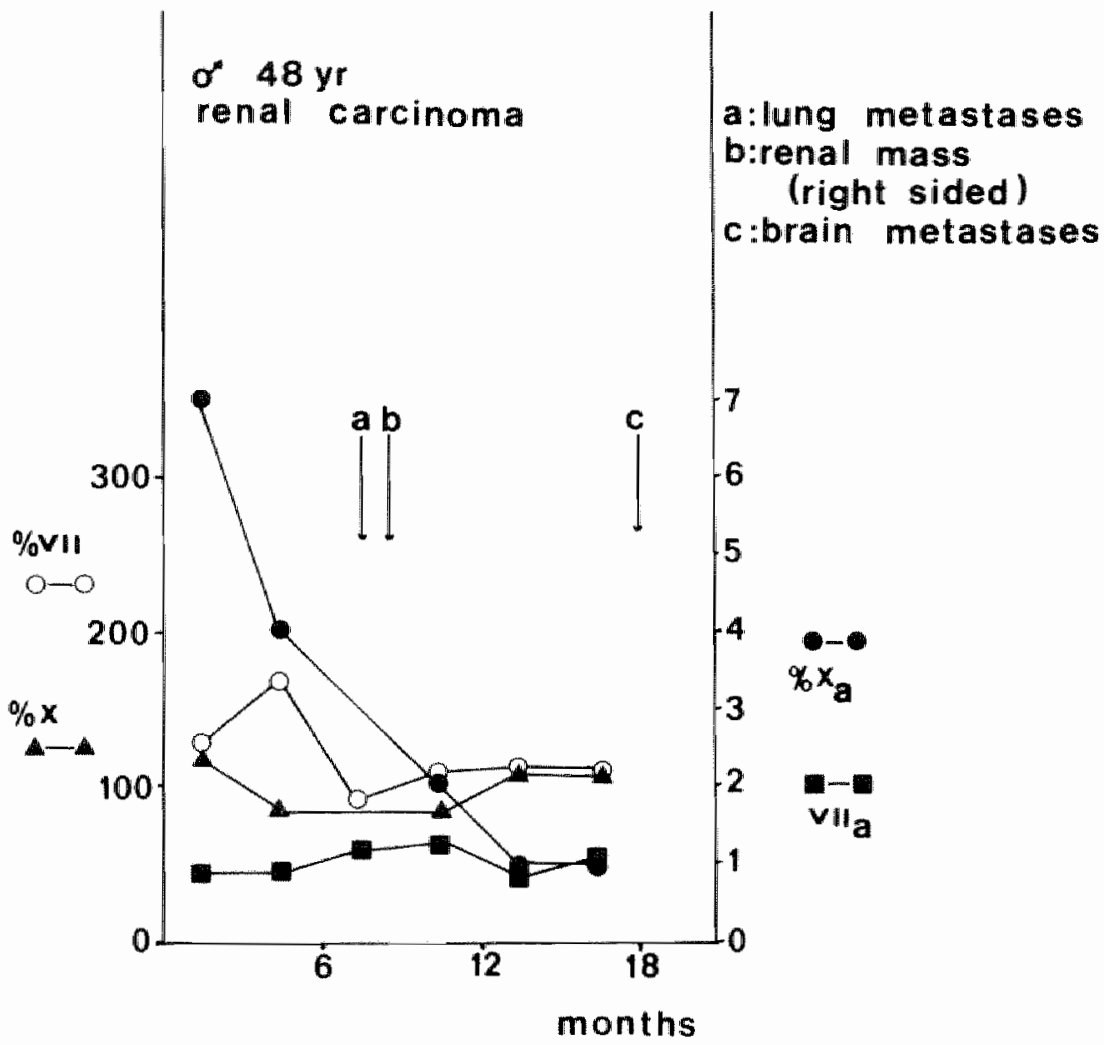

Figure 5. Plasma factors VII, VIIa, $X$ and $X a$ in a patient with progressive renal carcinoma. 


\section{Discussion}

With a few exceptions, activation of factor VII could not be detected in the plasma of our patients with metastatic cancer. Several explanations can be offered. Firstly, the method used might be insufficient to detect minor activation of factor VIII. Secondly, because of the short half-life of factor VIla $( \pm 6$ min.) plasma levels may not become high enough to detect substantial ongoing activation of blood coagulation in plasma. However, such an explanation is in contrast with the increased plasma FPA levels, which were reported in cancer patients with metastatic disease in spite of their short half-life of 3-5 min. $(3,6)$. Thirdly, the tumor types studied do not interact with blood coagulation via activation of factor VII. An explanation for the absence of factor VII activation might be that contrary to the in vitro situation (8), these tumors do not secrete microvesicles into the circulation with subsequent factor VII activation, or that these vesicles are rapidly cleared from the circulation. Fourthly, factor VII activation occurs only extravascularly without leakage of factor VIla into the circulation. Findings of Peuscher et al and Rickles et al that plasma FPA levels cannot be completely normalized by heparin infusion suggest that thrombin formation can continule in sites inaccessible for heparin, such as the extravascular space. Ongoing extravascular FPA formation could in this way contribute to circulating plasma FPA levels $(3,6)$. However, recent developments in the FPA determination question this explanation (see chapter I). Nevertheless, intra- and extravascular fibrin formation in the presence of factor $V I I$ and factor $X$ has at least been shown to occur in renal cell carcinoma (18). A final explanation for the absence of increased factor VIla levels is that factor VIla is known to activate factor $X$, while formation of factor $X a$ could lead to inactivation of factor VIlla (19). This feedback mechanism might explain why activation of factor VII could not be detected in our patients with metastatic disease, as $35 \%$ showed factor $X a$ levels above normal limits.

What can be the explanation of increased levels of factor $\mathrm{Xa}$ in the plasma of our patients with metastatic breast cancer? Normally, upon activation of factor $X$ on a phospholipid surface, factor $X a$ remains associated with the phospholipid surface, because it still possesses the gammacarboxyglutamic acid-containing domain responsible for the $\mathrm{Ca}^{2+}$-mediated binding to phospholipid membranes (20). Furthermore, free factor Xa in plasma is inhibited by AT III (21). However, low AT III levels and low alpha-2-antiplasmin levels (as a minor inhibitor of factor Xa in plasma) can not explain the increased plasma factor Xa levels as plasma levels of AT III and alpha-2-antiplasmin were normal in our patients. A possible explanation might be that our patients with metastatic cancer had 
circulating microvesicles, excreted by tumor cells or their accompanying activated phagocytic cells. These plasma membrane-derived microvesicles probably contain phospholipids and thereby cause an important extension in the contact surface between fumors and blood coagulation factors. Although direct factor $X$ activation by vesicles in an animal tumor model has only recently been suggested (22), reports of human tumor types point to factor $X$ activation by factor Vlla in in vitro experiments (8).

Whatever the cause of increased plasma factor Xa levels, they may be of clinical importance in breast cancer patients. Within the population of breast cancer patients, elevated factor Xa levels are quite specific though not very sensitive for the presence of metastases. However, the increased factor $X$ a levels do not reflect tumor progression and therefore cannot be used as a tumor marker for progression during follow-up of an individual patient.

Furthermore, we can conclude that the extent of malignant disease is unielated to the levels of blood coagulation parameters studied, with the exception of AT III. Apart from AT III this is in agreement with other investigators, who studied different blood coagulation parameters in relation with the state of the disease (23).

Plasma AT III levels were significantly lower in our patients with a more advanced state of disease, although still within normal limits. Nevertheless, we could not find lower plasma AT III levels in our patients with versus without metastases. This may be different in patients with significant liver metastases in whom plasma AT III levels are reported to be low (24).

In conclusion, increased plasma factor Xa levels were present in $35 \%$ of patients with metastatic disease, but differences between patients with or without metastases were only significant in breast cancer. The occurrence of manifest metastatic disease during longitudinal follow-up of individual patients is not associated with, let alone predicted by, changes in the blood coagulation parameters measured. Except for AT III levels, there is no relation between the extent of malignant disease and the plasma levels of the blood coagulation parameters. Activated blood coagulation factors VIla and Xa cannot be used for clinical purposes in cancer patients, with the possible exception of factor $\mathrm{Xa}$ in breast cancer patients. 


\section{References}

1. Sun N.C.J., McAfe W.M., Hum G.J., Weiner U.M.

Hemostatic abnomalities in malignamcy, a prospective study of one hundred eight patients. Part 1. Coagulation studies. Am. A. Cin. Pathol. 71: 10-16, 1970

2. Diewinko B., Schmidt D., Bollinger P., Keating M. Truhllo J.M. Coagulathon profles of untreated cancer patients. Proc. of Am. Soc. Cin Oncol 4: 19, 1985.

3. Peuscher F.W., Cleton E.J., Armstrong L, Stoepman van Dalen E.A, van Mourik I.A. van Aken W.G. Significance of plasma fibrinopeptide A (FPA) in patients with malignancy. I. Lab. Clin. Med. 96: 5-14, 1980.

4. Mannucci P.M.s. Vaglini M., Maniezzo M., Magni E., Mari D., Cascinell N. Hemostatic alterations are unrelated to the stage of tumor in untreated malignant melianoma and breast carcinoma. Eur. A. Cancer Chin. Oncol. 21:681-685, 1985.

5. Mombelli M., Roux A., Hofmann V., Straub P.W. Fibrinogenmetabolismus und Fibrinopeptid A in plasma bel disseminierten malignomen. Schweiz. Med. Wscht 109. $190 \%, 1979$.

6. Fickles F.R., Edwards R.L., Barb C., Cronlund M. Abnormalities of blood coagulation in patients with cancer: fibrinopeptide A generation and tumor growth.

Cancer 51: $301-307,1983$

7. Leeksma O. Fibrinagen, fibrinopeptide A, platelets and endothelial cells. Thesis, 1985

8. Dvorak H.F., Van Dewater L., Bitzer A.M., Dvorak A.M., Anderson D., Harvey V.S." Bach R., Davis G.L., De Wolf W., Carvalho A.C.A. Procoagulant activity associated with plasma membrane vesicles shed by cultured tumor celts.

Cancer Res. $43: 4334-4342,1983$.

9. Falanga A., Gordon S.G. Isolation and characterization of cancer procoagulant: a cysteine proteinase from malignant tissue. Biochemistry $24,5558-5567,1985$

10. Donati M.B., Gambaconti C., Passarini B., Falanga A., Fossati G., Semeraro N. Cancer procoagulant (factor $X$ activator) in tumor cells from patients with malignant melanoma. Thromb. Haemostas. 54: 259, 1985.

11. Broze G.J. Binding of human factor VII and $V l l a$ to monocytes. J. Clin. Invest 70:526-535, 1982.

12. Muller A.D., van Dam-Mieras M.C.E., Hemker H.C. Measurement of macrophage cellular procoagulant activity. Haemostasis 15: 108-113, 1985.

13. Deijk van W.A., van Dam-Mieras M.C.E., Muller A.D. Activation of factor Vhl in patients with carcinoma of the prostate, a preliminary report. Haemostasis $13: 198-200,1983$.

14. Bas B.M., Costongs G.M.P.J., Janson P.C.W. Rapid analysis of coagulation parameters by automated substrate methods with a Cobas Bio Centrifugal Analyser. Haemostasis, in press.

15. Haverkate F., Koopman J., Koppert P., Nieuwenhulzen W. Determination of fibrinfogen) degradation products (FDP) in plasma using a monoclonal antibody. Scand.J. Clin Invest. 45 (S 178): 153, 1985.

16. Babson A.L., Phillips G.E. An improved acid phosphatase procedure. Chin. Chim. Acta., 13: 264-265, 1966

17. Snedecor C.W., Cochran W.G. Statistical methods. Ames: lowa State University Press 130, 1976

18. Zacharski L.R., Memoli V.A., Rousseau S.M. Extrinsic coagulation activation in situ in renal cell carcinoma (RCC). Thromb. Haemostas. 54: 258,1985

19. Lammle B., Griffin J.H. Formation of the fibrin clot the balance of procoagulant and inhibitory factors. Clin. in Haemat. 14: 281-343, 1985.

20. Morita T., Kane W.H., Majerus P.W., Jackson C.M. Enzymatic properties of a derivative of activated factor $X$ from which the gammacarboxyglutamic acid-containing domain has been removed. In: The Regulation of Coagulation. Marin K. G., Taylor F.B. (eds.). Elsevier/North-Holland, New York. $187-188_{s} 1980$. 
21. Abldgaard $V$. Evidence that antithrombin lll is the main physiological inhibitor of coagulation enzymes. In: The Physiological Inthibitors of Blood Coagulation and Fibrinolysis. Collen D., Wiman B., Verstraete M. leds.). Elsevier/North Holland Amsterdam. $37 \times 33,9979$.

22. Morgan D., Edwards F.L. Rickles F.R. The tumor cell procoagulant of Lewis lung carcinoma is sedimentable and inhibited by lodo-acetamide. Thromb. Haemostas. 54 : 169,1985

23. Manucel P.M., Vaglïnl M., Maniezzo M., Magni E., Mari D., Cascinelli N. Hemostatic atterations are unrelated to the stage of tumor in untreated malignant melanoma and breast carcinoma. Eur. J. Cancer Clin. Oncol 21: 681-685, 1985.

24. Honegger H., Anderson N., Hewitt L.A., Tullis $\mathbb{J} . L$. Antithrombin III profiles in malignancy, relationship to primary tumors and metastatic sites. Thromb. Haemostas. (Stutgart) 46: 500-503, $198 \%$. 


\section{The influence of aminoglutethimide on plasma levels of medroxyprogesterone acetate: its relation with serum cortisol}

Based on: W.A. van Deijk, G.H. Blijham, W.A.M. Mellink, P.M.M. Meulenberg. Influence of aminoglutethimide on plasma levels of medroxyprogesterone acetate: its relation with serum cortisol. Cancer Treat. Rep. 69: 85-90, 1985.

\section{Introduction}

Before treating the effect of combined hormonal treatment on blood coagulation parameters in breast cancer patients, we will first describe the pharmacological interaction between the drugs in question in order to better understand their effects on blood coagulation parameters.

Aminoglutethimide (AG) in combination with hydrocortisone is an effective agent in the treatment of metastatic breast cancer in postmenopausal women (1). In randomized trials it has been found to have the same effectiveness as tamoxifen $(2,3)$. High-dose medroxyprogesterone acetate (MPA) given orally has been shown to cause tumor regression in 25\%-40\% of (partially) pretreated groups of postmenopausal patients (4). Adding MPA to AG has the advantage of combining two hormonal active agents which may act at least in part via different mechanisms. AG induces estrogen depletion by inhibiting the production of adrenal androgens and their peripheral conversion to estrogens (1). Progestins decrease the cellular estrogen receptor (ER) content and bind to androgen, glucocorticoid, and progesterone receptors in human breast cancer cells (5). Moreover, high-dose MPA has sufficient glucocorticoid effect to suppress endogenous cortisol production and to replace hydrocortisone in the combination with AG (6). Therefore, both cells responsive to treatment causing estrogen depletion and cells with receptors for other hormones present in the heterogenous breast tumor population can theoretically be killed by this combination; the additive antitumor effect of AG plus MPA has already been suggested by others ( 7 ).

Another reason for combining AG with MPA is that both agents are very effective in the palliation of pain and in objective amelioration of bone metastases $(2,8)$. 
Glutethimide is known to enhance the hepatic metabolism of other drugs (9); $A G$, its amino derivative, may be expected to have a similar effect. We were particularly interested in its effect on plasma MPA levels because AG has aiso been shown to enhance the metabolism of another synthetic steroid, dexamethasone (10). Increased MPA metabolism may lead to plasma MPA levels insufficient to maintain an adrenal suppressive state or to exert a meaningful antitumor activity. Therefore, one of the main purposes of our pilot study with AG plus MPA in postmenopausal patients with advanced breast cancer was to investigate the interaction between the two drugs as far as plasma MPA and cortisol levels are concerned.

\section{Patients and methods}

Postmenopausal patients with metastatic breast cancer with a positive ER ( $>10 \mathrm{fmol} / \mathrm{mg}$ of protein) or with an unknown ER and disease free interval of $>2$ years were eligible for this study. Some of the patients were pretreated with other forms of hormonal therapy (ovariectomy, tamoxifen) or chemotherapy; all pretreated patients were off prior treatment for at least 1 month. After further staging the patients were treated with oral MPA at a dose of $500 \mathrm{mg}$ three times daily. After 2 weeks AG was added in a dose of $250 \mathrm{mg}$ twice daily, which after another 2 weeks was increased to $250 \mathrm{mg}$ four times daily. Pharmacologicall and endocrinological studies were performed at day 0 after 2,4 and 8 weeks so that measurements were obtained before MPA, with MPA only, and with the combination of MPA and $A G$ at half and full dose of the latter drug. On the study days patients were admitted to our outpatient clinic early in the morning after an overnight fast, where they were asked to take their first $500 \mathrm{mg}$ of MPA (with or without $250 \mathrm{mg}$ of AG) of the day. After 30 minutes the patients were brought into supine position, and an indwelling venous catheter for blood sampling was placed. After another 30 -minute rest blood samples were taken between 9 and $10 \mathrm{a} . \mathrm{m}$. for hormonal assays and plasma MPA level determination. Sampling for the latter determination was repeated after 2, 3, 4 and 6 hours. Blood samples for hormonal assays were collected as serum and those for MPA assays were collected as plasma (heparinized tubes). All samples were collected on ice, immediately centrifuged, and frozen at $-20^{\circ} \mathrm{C}$ until assayed.

Serum cortisol was measured by a radioimmunoassay (RIA) kit (Diagnostic Products Corp; normal values, $220-660 \mu \mathrm{mol} / \mathrm{l}$ ).

Plasma MPA was determined by a combination of the methods described by Laatikainen et al (11) and Shrimanker et al (12) with minor modifications. The procedure was as follows: to $250 \mu l$ of plasma was added $50 \mu \mathrm{l}$ of $3 \mathrm{H}-\mathrm{MPA}(60 \mathrm{Ci} / \mathrm{mmol}$; New England Nuclear Corp. Boston, MA) and $5000 \mathrm{cpm} / 50 \mu l$ of PG buffer [0.1 M 
phosphate buffer ( $\mathrm{pH} 7.0$ ) and $0.1 \%$ gelatin]. After 20 minutes equilibration the mixture was extracted with $5 \mathrm{ml}$ of petroleum ether $\left(40^{\circ} \mathrm{C}-60^{\circ} \mathrm{C}\right)$, the waterphase frozen, and the organic layer decanted in another tube and evaporated.

The dried residue was suspended in $1.5 \mathrm{ml}$ of PGM buffer $[0.1 \mathrm{M}$

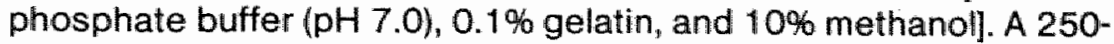
$\mu l$ portion of this solution was used for recovery counting and $250 \mu$ was pipetted in duplicate into polystyrene RIA tubes. One-hundred microlitres of $3 \mathrm{H}-M P A( \pm 5000 \mathrm{cpm} / 100 \mu \mathrm{l}$ of PGM) and $100 \mu \mathrm{l}$ of antiserum (Farmitalia; dilution 5000 in PGM) were added. Following overnight incubation at $4^{\circ} \mathrm{C}$ the free and bound fractions were separated by addition of $250 \mu 1$ of $2 \%$ charcoal and $0.2 \%$ dextran solution in PG plus $5 \%$ methanol and centrifugation. The supernatant was decanted and counted. Technical details of the separation procedure have been described previously (13). In vitro addition of AG to plasma from patients using MPA only had no influence on plasma MPA levels (personal experience). Paper chromatography and high-pressure liquid chromatography show that after extraction with petroleum ether, two still unidentified metabolites cross-react with the antiserum used.

Seven patients have been studied. A paired t test was used to compare plasma MPA levels before and after the addition of AG. For the relation between plasma MPA and serum cortisol levels, a log curve-fitting program was used and the correlation coefficient was calculated.

\section{Results}

The plasma MPA levels at 1-6 hours after 500 mg of MPA orally before and after the addition of half- or full-dose $A G$ in seven patients are shown in figures 1-3. Individual patients are represented by the same symbol in each of these three figures. Large interindividual differences were found; moreover, the steady state achieved by prior drug administration was such that in many patients no clear-cut ingestion-related variations could be found, so that it was impossible to calculate MPA half-lives. In figure 4 the mean MPA plasma levels for the seven patients before and after addition of AG are shown. The plasma MPA levels appeared to decrease significantly by $>50 \%$ after addition of $A G(p<0.005)$. This decrease had already been reached after 2 weeks of $A G$ at the dose of $250 \mathrm{mg}$ twice daily. The relation between plasma MPA levels and serum cortisol levels during treatment with MPA with or without $A G$ is shown in figure 5 . The correlation coefficient between plasma MPA and serum cortisol levels was 0.89 , showing a highly significant relationship between the two parameters $(p<0.001)$. 


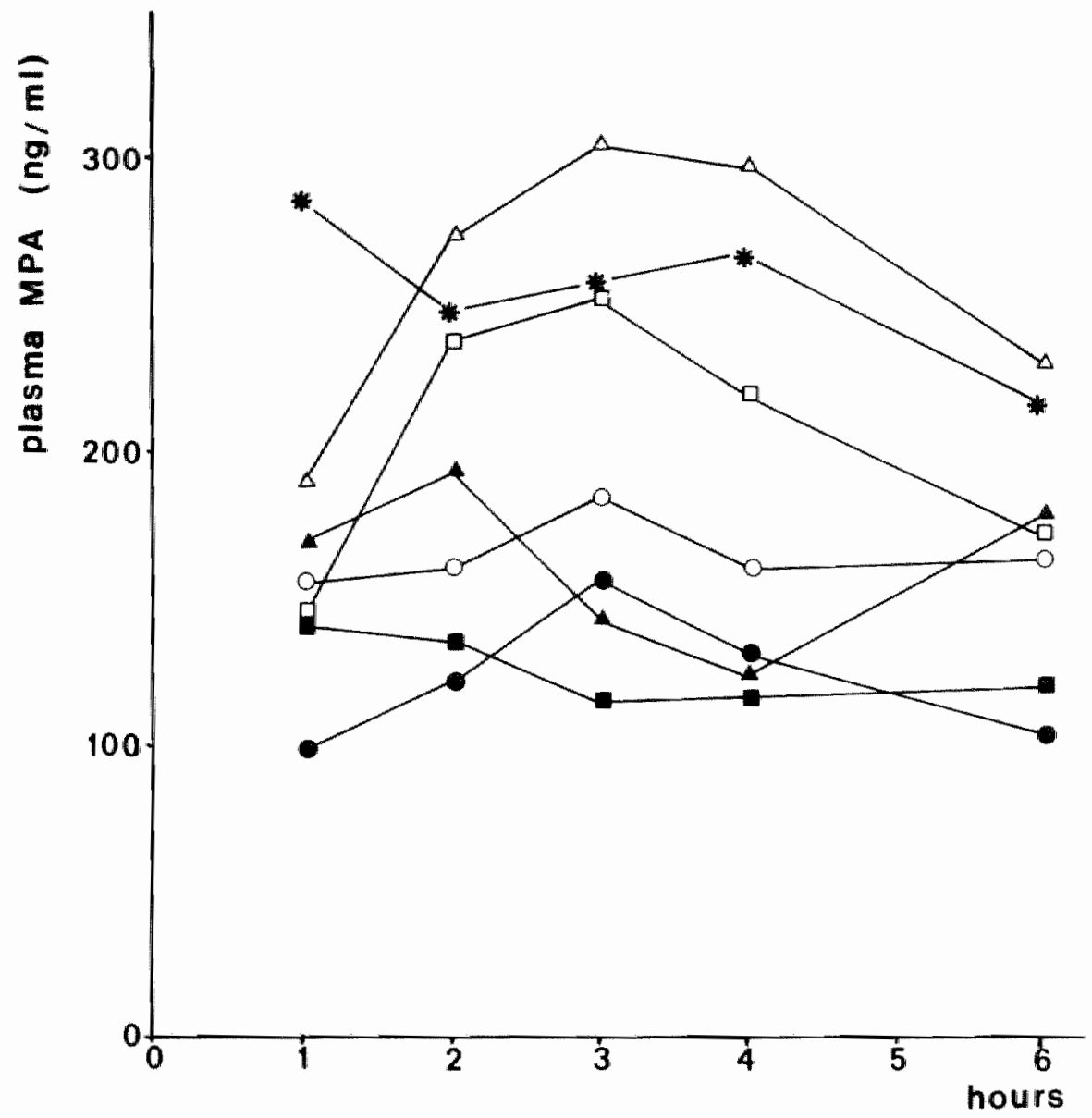

Figure 1. Individual plasma MPA levels studied for 6 hours after ingestion of $500 \mathrm{mg}$ of MPA during treatment with MPA at a dose of $1500 \mathrm{mg}$ daily for 2 weeks. Identical symbols represent sequential plasma MPA determinations in 1 patient. 


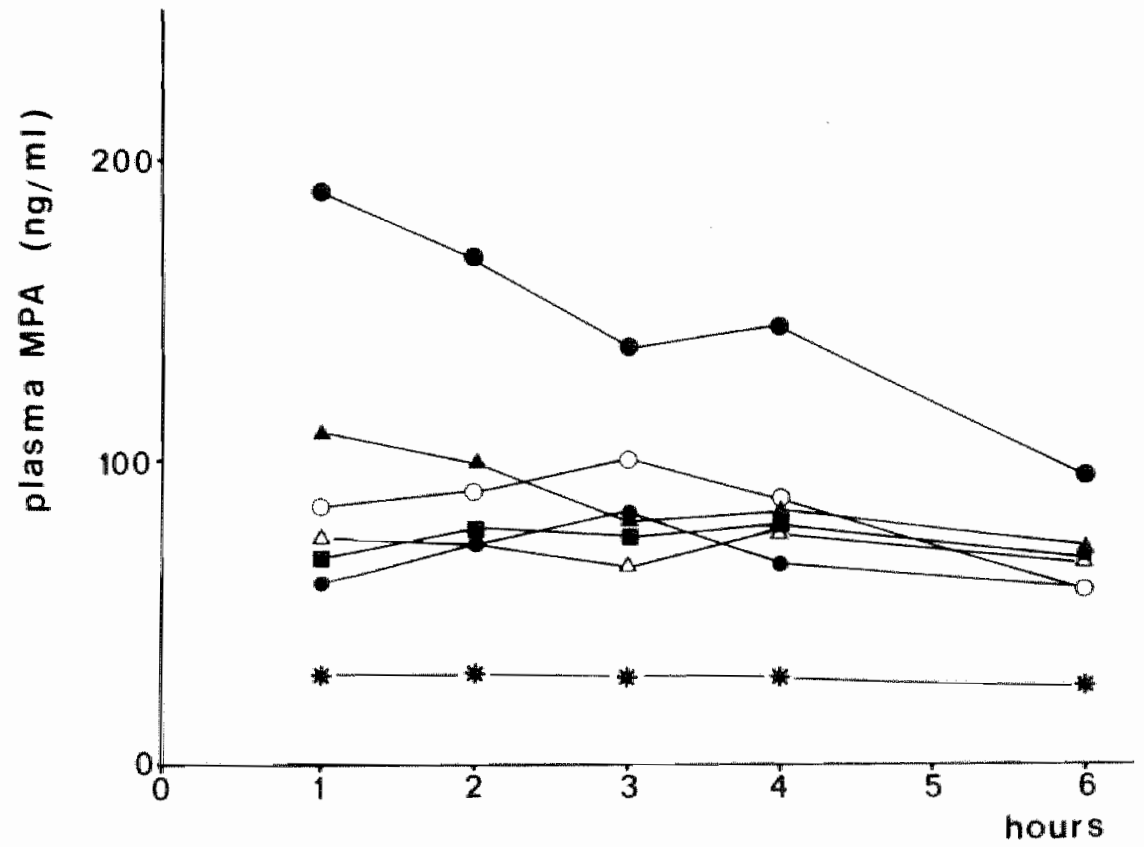

Figure 2. Individual plasma MPA levels studied for 6 hours after ingestion of $500 \mathrm{mg}$ of MPA and $250 \mathrm{mg}$ of $\mathrm{AG}$ during treatment with MPA at a dose of $1500 \mathrm{mg}$ daily and AG at a dose of $500 \mathrm{mg}$ daily for 2 weeks. Symbols represient the same individual patients as those in figure 1 . 


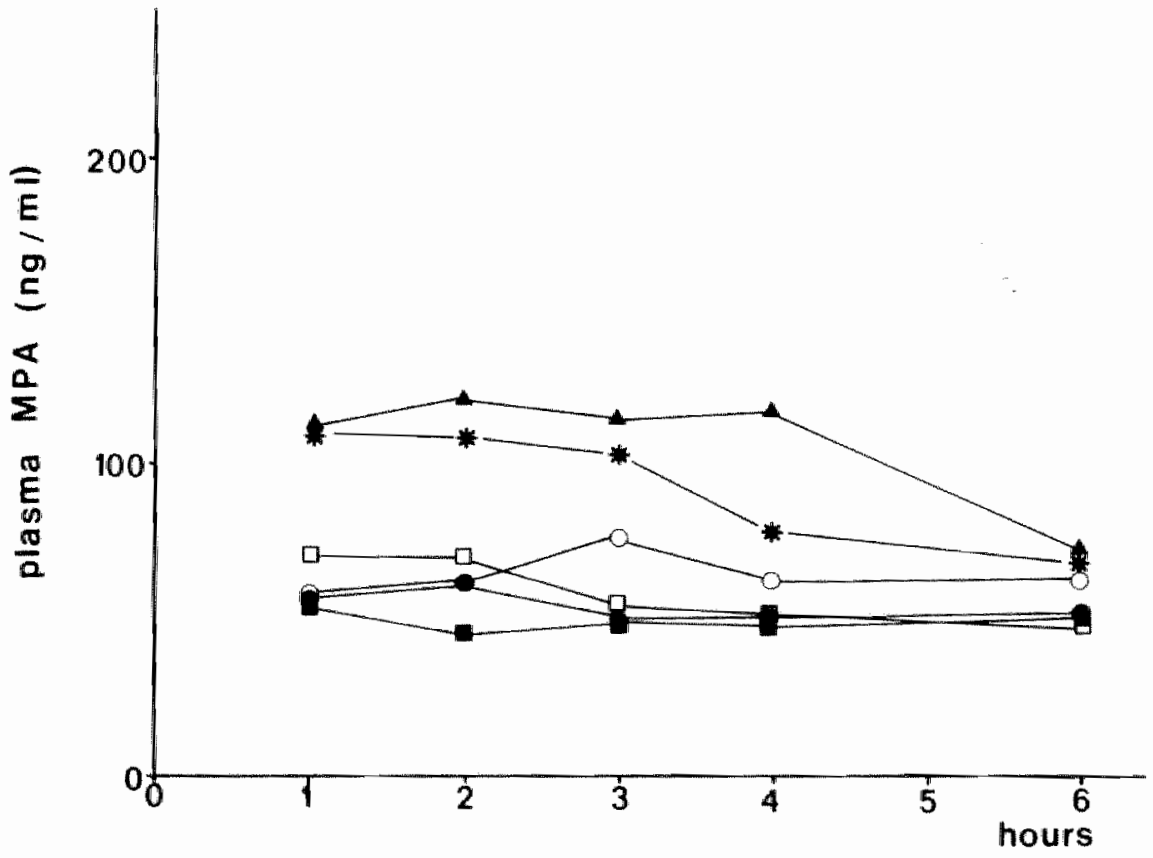

Figure 3. Individual plasma MPA levels studied for 6 hours after ingestion of $500 \mathrm{mg}$ of MPA and $250 \mathrm{mg}$ of AG during treatment with MPA at a dose of $1500 \mathrm{mg}$ daily and AG at a dose of $1000 \mathrm{mg}$ dailly for 4 weeks. Symbols represent the same individual patients as those in figure 1 and figure 2. 


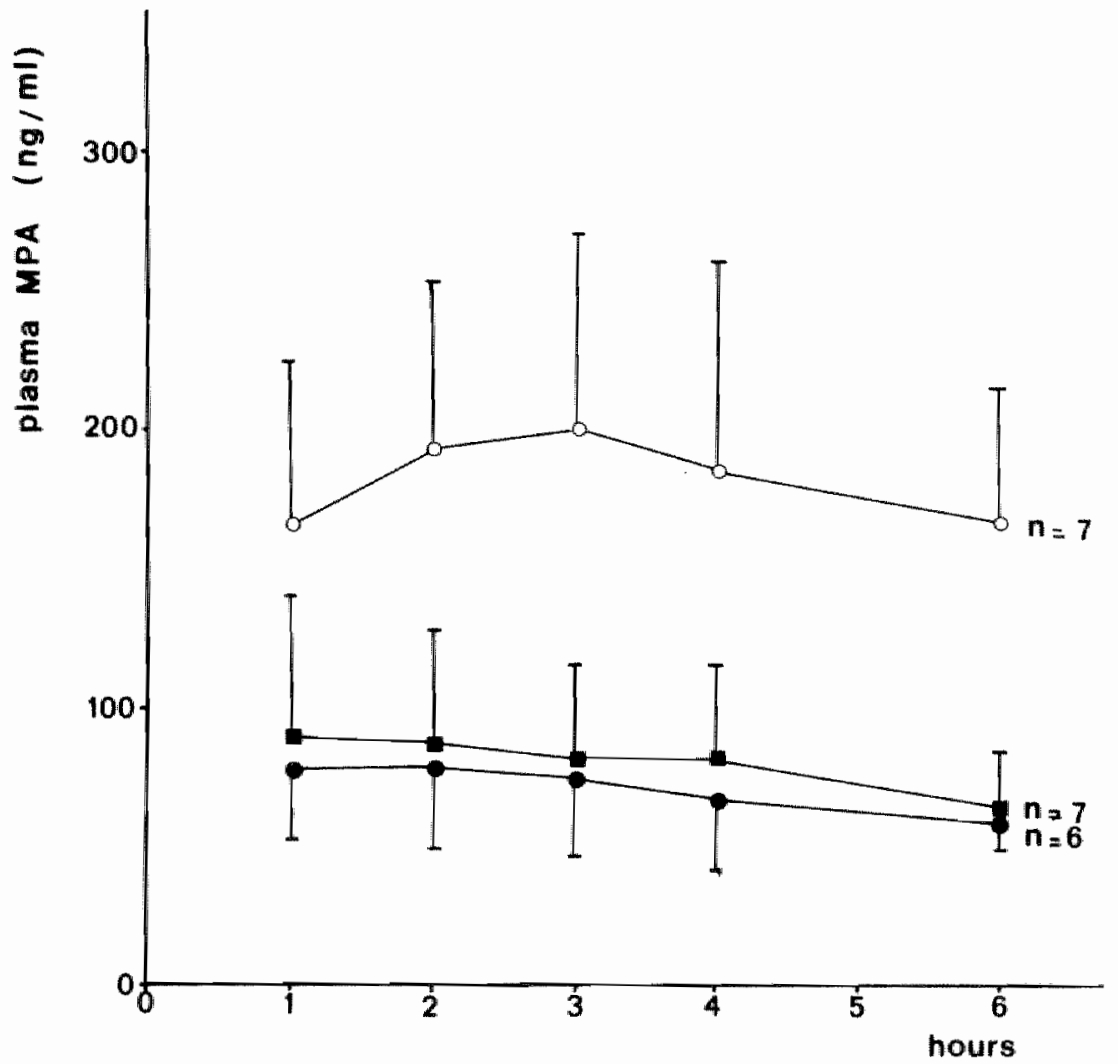

Figure 4. Mean plasma MPA levels ( \pm SD) studied for 6 hours after ingestion of $500 \mathrm{mg}$ of MPA during treatment with MPA at a dose of $1500 \mathrm{mg}$ daily $(\mathrm{O}-\mathrm{O}$ ), after ingestion of $500 \mathrm{mg}$ of MPA $+250 \mathrm{mg}$ of AG during treatment with MPA at a dose of $1500 \mathrm{mg}$ daily + AG at a dose of $500 \mathrm{mg}$ daily (C - and during treatment with MPA at a dose of $1500 \mathrm{mg}$ daily $+\mathrm{AG}$ at a dose of $1000 \mathrm{mg}$ daily (O - $)$. 


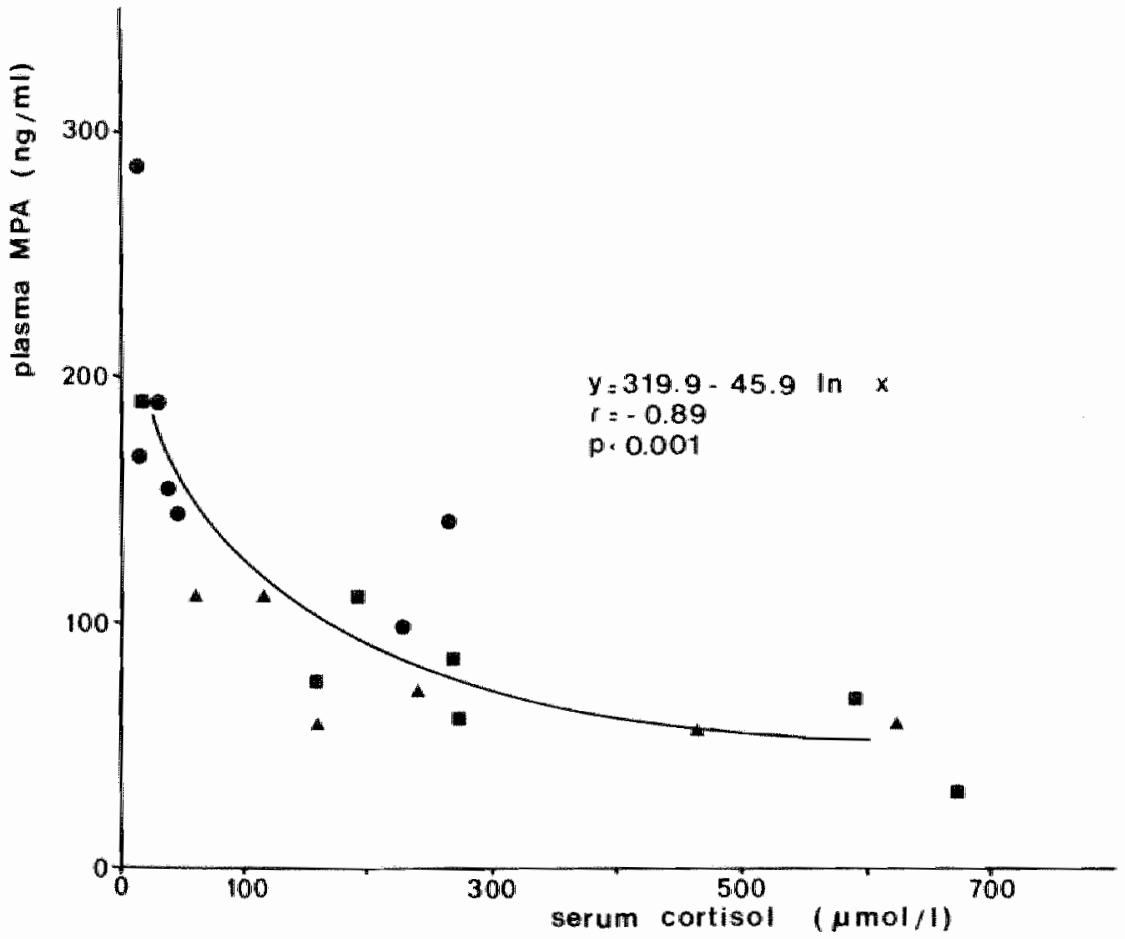

Figure 5. Correlation between serum cortisol and plasma MPA levels using a log curve fit. - $=$ MPA at a dose of $500 \mathrm{mg} 3$ times / day; $=$ MPA at a dose of $500 \mathrm{mg} 3$

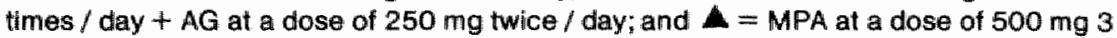
times / day + AG at a dose off $250 \mathrm{mg} 4$ times / day. 


\section{Discussion}

Pllasma MPA levels were shown to decrease by $>50 \%$ after combining oral MPA at a dose of $1500 \mathrm{mg}$ daily with $\mathrm{AG}$. Santen et al (10) observed a comparable decrease in serum dexamethasone levels after the addition of $A G$ for 2 weeks. This is probably due to an increased metabolism of these steroids secondary to hepatic microsomal enzyme induction by AG. Steroid metabolism is altered by drugs such as some anticonvulsants and tuberculostatics by their hepatic microsomal enzyme-inducing activity. For instance, serum llevels of progesterone and its metabolites decrease after administration of phenobarbital despite a relative increase in hydroxylated metabolites resulting from increased activity of progesterone hydroxylases (14). Metabolism of MPA is largely unknown, and no data regarding the influence of hepatic enzymeinducing drugs on MPA metabolism are available. The RIA used in our study measures unchanged MPA as well as at least two chromatographically identified metabolites (unpublished); the exact nature as well as biological activity of these metabolites is unknown. On the other hand, MPA metabolites hydroxylated in $\mathrm{C} 21$, which are known to possess glucocorticoid activity, are not detected by the antibody (12). Nevertheless, the close correlation, observed by us and others (15), between serum cortisol and plasma MPA levels suggests that the RIA is able to measure MPA-associated glucocorticoid activity reliably, whether or not exerted by MPA alone or in conjunction with one or more metabolites. This glucocorticoid activity is clearly reduced after administration of AG, presumably by interference of this drug with MPA metabolism. Further studies using chromatographical methods and enzyme studies are needed to further clarify the exact nature of this interference.

Gupta et all (16) reported an unchanged metabolic clearance rate for i.v. administered MPA during treatment with AG. Therefore, alternative explanations for the lower time-concentration curves of plasma MPA after addition of AG have to be considered. Camaggi et al (17) showed that with $1500 \mathrm{mg} /$ day of MPA administered orally, plateau levels of plasma MPA between 100 and $150 \mathrm{ng} / \mathrm{ml}$ could be sustained for as long as 4 weeks. With the same treatment, Blossey et al (15) found plasma MPA levels to be more or less unchanged for 4 months, keeping serum cortisol suppressed. The lowering of the plasma MPA levels during the treatment period with $A G$ therefore cannot be explained as being a normal course of plasma MPA concentrations during treatment with these high doses. On the other hand, the possibility that $A G$ interferes with the intestinal absorption of MPA tablets cannot be completely excluded, although we are not aware of AG having such an effect or of a possible mechanism of such interference. 
Which are the implications of our findings for the treatment with the combination of AG and MPA? As shown in figure 5 , plasma MPA levels of about $>100 \mathrm{ng} / \mathrm{ml}$ are necessary to obtain and maintain subnormal serum cortisol values. Such values were almost uniformly obtained with $1500 \mathrm{mg}$ of MPA daily; however, they occurred only rarely after the addition of 500 or $1000 \mathrm{mg}$ of $\mathrm{AG}$. These results confirm findings of $\mathrm{Nagel}$ et al (6). The relatively high response rate with high dose of MPA in patients with advanced breast cancer (18) and the lack of dose response relationship at lower doses (19) does suggest that to achieve high response rates effective adrenal suppression and therefore MPA levels of $>100 \mathrm{ng} / \mathrm{ml}$ are necessary. In that case AG would at least in part be antagonistic to MPA, since it leads to lower plasma MPA levels and less adrenal suppression. Whether or not this makes the AG plus MPA combination less effective than, for example, AG plus hydrocortisone can only be established by performing a randomized trial.

In summary, from this pharmacological study two conclusions can be drawn. Firstly, plasma MPA levels correspond to serum cortisol levels; in future trials with MPA correlations between plasma MPA levels, serum cortisol levels, and response should be further investigated. Secondly, AG leads to a lowering of plasma MPA levels to such an extent that adrenal suppression may be diminished or even abrogated. Further investigation regarding this combination should take these findings into account and consider a further increase in MPA or a decrease in AG dosages. The latter alternative may be attractive in view of recent evidence, suggesting that $250 \mathrm{mg}$ of AG may be therapeutically as good as the more conventional higher doses $(20,21)$. 
1. Santen R.J., Brodie A.M.H. Suppression ol estrogen production as treatment of breast carcinoma: pharmacological and clinical studies with aromatase imhibitors. Clin. Oncol. 1: $77-130,1982$.

2. Smith 1.E., Harris A.L., Morgan H., Ford H.T., Gazet J.C., Harmer C.L., White H., Parsons C.A., Villardo A., Walsh G., McKinna J.A. Tamoxifen versus aminoglutethimide in advanced carcinoma: a randomized crossover trial. $8 \mathrm{r}$. Med. 4.283 : $1432-1434,1982$.

3. Lipton A., Harvey M.A., Santen R.J., Boulcher A.. White D., Bernath A., Dixon R., Richards G., Shafik A. Randomized trial of aminoglutethimide versus tamoxifen in metastatic breast cancer. Cancer Res. 42: 3434-3436, 1982.

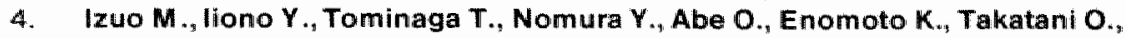
Kubo K., for the research group for the MPA treatment of breast cancer in Japan. Oral high dose medroxyprogesterone acetate therapy in advanced breast cancer: clinical and endocrine results. In. Proceedings of the International Symposium on Medroxyprogesterone Acetate Cavalli F. MoGuire WL.. Parnuti F.et al (eds.). Excerpla Medica, Amsterdam. 250-263, 1982.

5. Teulings F.A.G., van Gillse H.A., Henkelman H.S., Portengen H., AllexievaFigusch J. Estrogen, androgen "glucocarticoid, and progesterone receptors in progestin-induced regression of human breast cancer Cancer Res. 42:3442-3444, 1982.

6. Nagel G.A., Wander H-E., Blossey H-C. Phase II study of aminoglutethimide and medroxyprogesterone acetate in the treatment of patients with advanced breast cancer. Cancer Res. 42: 3442-3444, 1982.

7. Wander H-E., Nagel G.A., Blossey H-C. Medroxyprogesteronacetat (MAP) und Aminoglutethimid (AG) beim metastasierenden Mammakarzinom. Onkologie-Sonderhelt zu Band 5: 28-33, 1982 .

8. Pannuti F., Burroni P., Fruet F. Anabolizing and antipain effect of the short-termtreatment with medroxyprogesterone acelate (MPA) at high oral doses in oncology. Panminerva Med. 22: 149-156, 1980.

9. Morelli H.F, Melmon K.L. Drug interactions. In: Clinical Pharmacology Macmillan Publishing Co. Inc. New York. 982-1007, 1978.

10. Santen R.J., Lipton A., Kendall $\mathbb{J}$. Succesful medical adrenalectomy with aminoglutethimide. Role of altered drug metabolism. J.A.M.A. 230: 1661-1665, 1974.

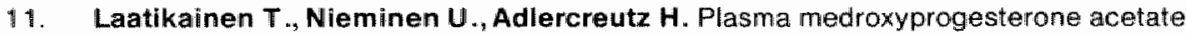
levels following intramuscular or oral administration in patients with endometrial adenocarcinoma. Acta Obstet. Gynecol. Scand. 58: 95-99, 1979.

12. Shrimanker K., Saxema B.N., Fotherby K. A radioimmunoassay for serum medroxyprogesterone acetate. Steroid Biochem. 9: 359-363, 1978.

13. De Man A.M.M., Benraad Th.J. Aldosterone secretion rate: radioimmunoassay versus double isotope dilution derivative assay. Clin. Chim. Acta $79: 489-501,1977$.

14. Feuer G. Drug control of steroid metabolism by the hepatic endoplasmic reticulum Drug Metab. Rev. 134: 1119-1144, 1983.

15. Blossey H.C. Wander H.E., Nagel G.A., Köbberling J., Kleeberg U. Medroxyprogesteronacetat in hoher Dosierung beim metastasierenden Mammakarzinom. Onkologie-Sonderheft zu Band 5: 13-16, 1982.

16. Gupta C., Osterman $J_{*}$ Santen R., Bardin C.W. In vivo metabolism of progestins. V. The effect of protocol design on the estimated metabolic clearance rate and wolume of distribution of medroxyprogesterone acetate in women. 4 . Clin. Endocrinol Metab. 48 : 816-820, 1979 high-dose administration in advanced cancer patients. Cancer Chemother. Pharmacol. 11: 19-22, 1983. 
18. Lobur J. Mouridsen H.T., Rose C. Oral or intramuscular treatment of advanced breast cancer with medroxyprogesterone acetate: a review.

In: Aole of Medroxyprogesterone in Endocrine Aelated Tumors. Campio L Robustell della Cuna G. Taylor A.W. (eds.). Raven Press. New York. 2: 105-114, 1983.

19. Rose C. Mouridsen H.T., Engelsman E., Nooi M., Sylvester R., Rotmenz N., for the EORTC Breast Cancer Cooperatiwe Group. Treatment of advanced breast cancer with medroxyprogesterone acetate: randomized evaluation of the dose-response relationship at two-dose leveis. A phase Illi trial. J. Steroid Brochem, 19: 202 s, 1983.

20. Cantwell B.M J., Sainsbury J R C ., Harris A L., Wilson R G., Farndon $\mathrm{J}$. Dawes P.J.D.K. Dowsett J. Low dose aminoglutethinide: a phase II study in advanced postmenopausal breast cancer. 2nd European Conference on Chinical Oncology and Cancer Nursing, Amsterdam, 185, 1983.

21. Bonneterre J., Coppens H., Mauriac L., Rouesse J., Metz R., Armand J.P., Fargeot P., Tubiana M., Mathieu A., Cappeliaere P. Aminoglutethimide therapy in palients with advanced breast cancer. 2nd European Conference on Clinical Oncology and Cancer Nursing, Amsterdam, 187, 1983. 


\section{Blood coagulation enzyme profiles before and during treatment of advanced breast cancer with high-dose medroxyprogesterone acetate and aminoglutethimide}

\section{Introduction}

In the endocrine treatment of metastatic breast cancer the goal is to interfere with the interaction between hormones and tumor cells. This can be achieved by altering circulating hormone levels or by blocking the interaction between hormones and their receptors in tumor cells. Although the exact mechanism of its antitumor activity is unknown, high-dose medroxyprogesterone acetate (MPA) interacts with several tumor cell receptors, among which the estrogen receptor (1). Moreover, in spite of the large interindividual differences in plasma MPA levels reached, oral high dose MPA. $1500 \mathrm{mg}$ daily, usually exerts a glucocorticoid effect. This leads to hypophyseal inhibition of ACTH secretion, followed by decreased cortisol and androgen synthesis in the adrenal cortex $(2,3)$. in recent years high-dose MPA has shown to be an effective hormonal agent in the treatment of metastatic breast cancer in postmenopausal patients $(4,5)$. Among its adverse effects thrombophlebitis, thrombosis and pulmonary embolism have been reported. The incidence of such complications is considered to be low $(1-4 \%)(6,7)$. In the past, several progestagens, mostly used in low dose for other purposes such as contraceptive agents, have been studied for their effects on the haemostatic system. Generally, in contrast to the use of estrogens, no major changes were found and for those changes that have been reported in the literature there is little consensus among the authors $(6,7,8,9,10)$. Differences in type and dose of progestagens, their use in combination with estrogens and differences in sampling and assay methodology contribute to this variability.

In postmenopausal women adrenal androgens are the only source of importance in the production of estrogens. They are converted to estrogens in peripheral tissues by the enzyme aromatase (11). We added aminoglutethimide (AG) to high-dose MPA in an effort to achieve a better anti-tumor effect. AG inhibits several enzymes in the adrenal cortex leading to decreased cortisol and androgen production. More importantly, AG almost completely inhibits the enzyme aromatase in peripheral tissues, such as muscle, fat and 
breast, preventing the conversion of androgens to estrogens. The adrenal enzyme inhibition induced bij AG will in time be abolished by increased hypophyseal ACTH secretion in reaction to low serum cortisol. This may be prevented by adding a glucocorticoid such as hydrocortisone acetate or, as in this study, high-dose MPA (12, 13), $\mathrm{AG}$ plus $\mathrm{HC}$ has shown to be among the most effective hormonal treatments in metastatic breast cancer in postmenopausal patients (12). As far as we know, no thromboembolic disease has been reported in relation to this treatment. We performed a prospective study of the level and activity state of blood coagulation enzymes before and during hormonal treatment with high-dose MPA alone and in combination with $A G$ in postmenopausal patients with breast cancer.

\section{Patient Characteristics}

Twenty postmenopausal patients with recurrent or progressive metastatic breast cancer were studied. Mean age 63.2 years, range 45-83 years. Sites of disease varied from soft tissue only to multiorgan localizations. No patient had manifest liver metastases. Two out of twenty patients had thromboembolic disease during treatment. One had thrombophlebitis of the left upper arm, coexistent with axillary tumor growth. The other patient had deep vein thrombosis of the leg and pulmonary embolism eight weeks after the start of the treatment.

No patient had a manifest bleeding tendency. All patients were off previous treatment for at least one month.

Scheme of treatment

\begin{tabular}{|c|c|c|c|}
\hline weeks & 1 and 2 & 3 and 4 & $>4$ \\
\hline $\begin{array}{ll}\text { MPA } & (\mathrm{mg} / \mathrm{d}) \text { p.o. } \\
\mathrm{AG} & (\mathrm{mg} / \mathrm{d}) \text { p.o. }\end{array}$ & $\begin{array}{c}1500 \\
-\end{array}$ & $\begin{array}{r}1500 \\
500\end{array}$ & $\begin{array}{l}1500 \\
1000\end{array}$ \\
\hline
\end{tabular}

Sampling procedure

Sampling occurred at day 0 of the treatment, at the end of week 2, week 4 and week 8 . One patient was not sampled at day 0 , one patient not at week 2 and six patients not at week 8 . The last six patients had been taken off treatment at that time because of progressive disease, in the other two cases sampling was omitted for practical reasons.

On the sampling days patients were admitted to our outpatient clinic in the morning after an overnight fast. Then they were asked to take their first $500 \mathrm{mg}$ MPA (with or without $250 \mathrm{mg} \mathrm{AG}$ ) of the day. 
After 30 minutes the patients were brought into supine position and an indwelling plastic venous catheter was placed for blood sampling. To create basal conditions for hormonal assays, another 30 -minute rest followed. Then blood samples were obtained after a period of stasis as short as possible and the samples were collected in plastic tubes containing trisodium citrate. $2 \mathrm{H}_{2} \mathrm{O}$ (final concentration $0.109 \mathrm{M}$ ). The first few millilitres of blood were discarded. Platelet poor plasma was prepared and stored as described in Chapter $V$. At the same time blood samples for hormonal assays and MPA determinations were taken and stored as described in Chapter VI.

All blood sampling occurred between 9.00 and 10.00 hrs. a.m.

\section{Materials and Methods}

Factor VII, factor VIIa and the cold promoted activation of factor VII were determined as described in Chapter III. Normal values factor VII : 55-129\%, factor VIIa: 0.61-1.41.

Factor $X$, factor Xa and antithrombin III (AT III) were determined as described in Chapter $V$. Normal values factor $X: 61-1.44 \%$, factor Xa: $<5 \%$, AT III: $77-131 \%$.

Fibrinogen, factor XII and prothrombin time (PT) were determined by a modification of the methods of Veltkamp et al (14). Normal values fibrinogen: $1.7-4.0 \mathrm{~g} /$, factor $X 11:>50 \%$, prothrombin time: $14.6-15.2 \mathrm{sec}$.

Serum Cortisol was determined by radioimmunoassay (RIA) (Diagnostic Products Corp, U.S.A.). Normal values $220-660 \mu \mathrm{mol} /$. Serum estrone was determined by RIA (BühImannLaboratories Ltd, Basel, Switzerland). Normal values for postmenopausal women: 70-550 pmol/A.

Serum estradiol was determined by RIA (Eidg. Institut für Reaktorforschung, Würenlingen, Switzerland). Normal values for postmenopausal women: 40-200 pmol/.

Plasma MPA was determined by RIA after extraction with petroleum ether as described in Chapter VI.

\section{Statistical analysis}

The Student 's paired t test was used to compare results of coagulation and hormonal studies before and during treatment. For correlation studies curve fitting programs were used and the correllation coefficient determined. For the occurrence of cold promoted activation of factor VII before and during treatment the McNemmar test was used. 


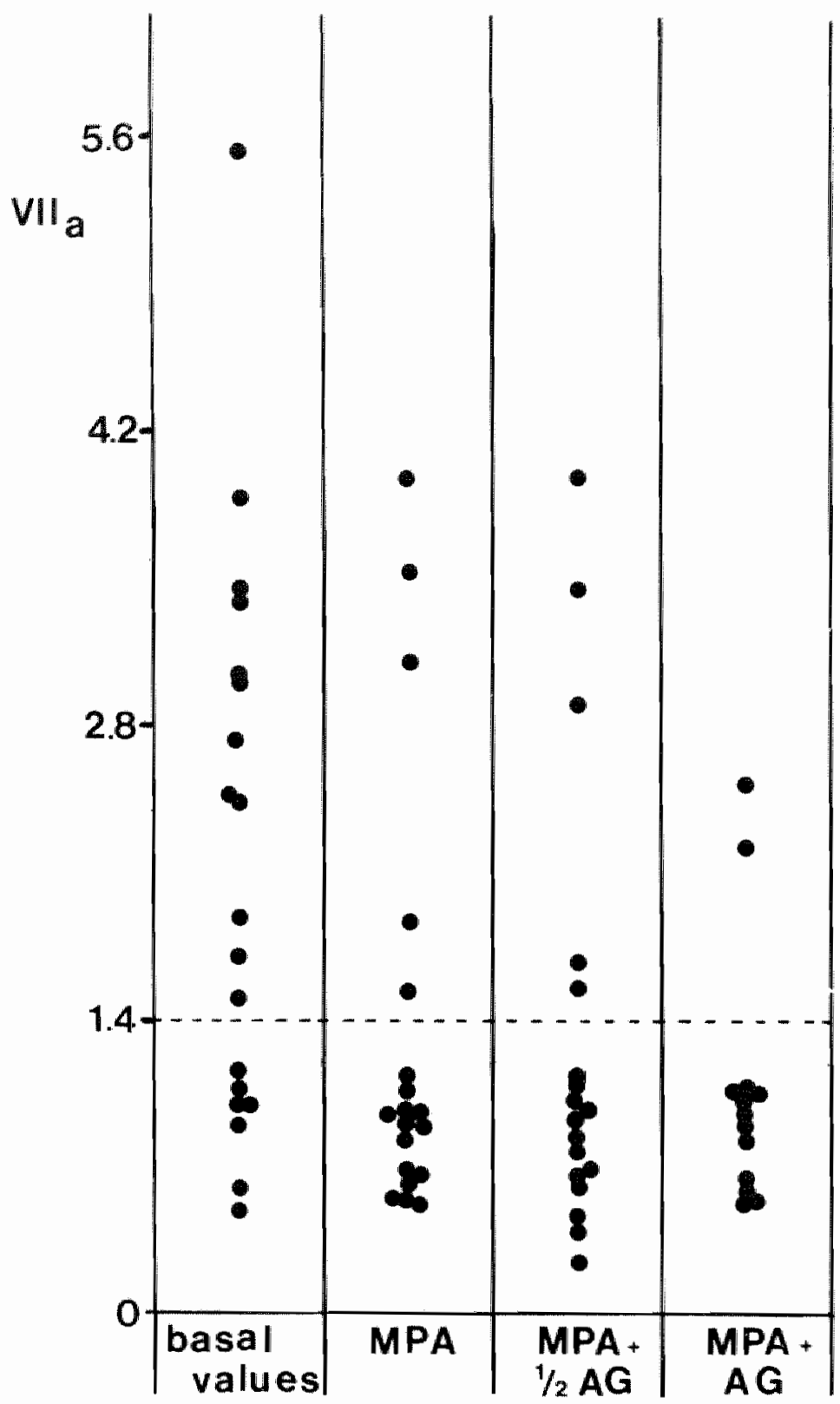

Figure 1. The cold-promoted activation of factor VII in postmenopausal patients with advanced breast cancer before and during treatment with $1500 \mathrm{mg}$ MPA daily. $1500 \mathrm{mg}$ MPA plus $500 \mathrm{mg}$ AG daily (MPA + 1/2 AG) and $1500 \mathrm{mg}$ MPA plus $1000 \mathrm{mg}$ AG daily (MPA + AG). The decrease observed during treatment is signiticant $(p<0.05)$. 


\section{Table 1}

Results $\# \mathrm{SD}$ of coagulation assays detemined before and during treatment with MPA, $1500 \mathrm{mg}$ daily and after addition of $\mathrm{AG}, 500 \mathrm{mg}$ daily ( $\mathrm{H} / \mathrm{AG}$ ) and $1000 \mathrm{mg}$ daily (AG). For factor Xa only the median values are given as the levels found were not normally distributed about the mean.

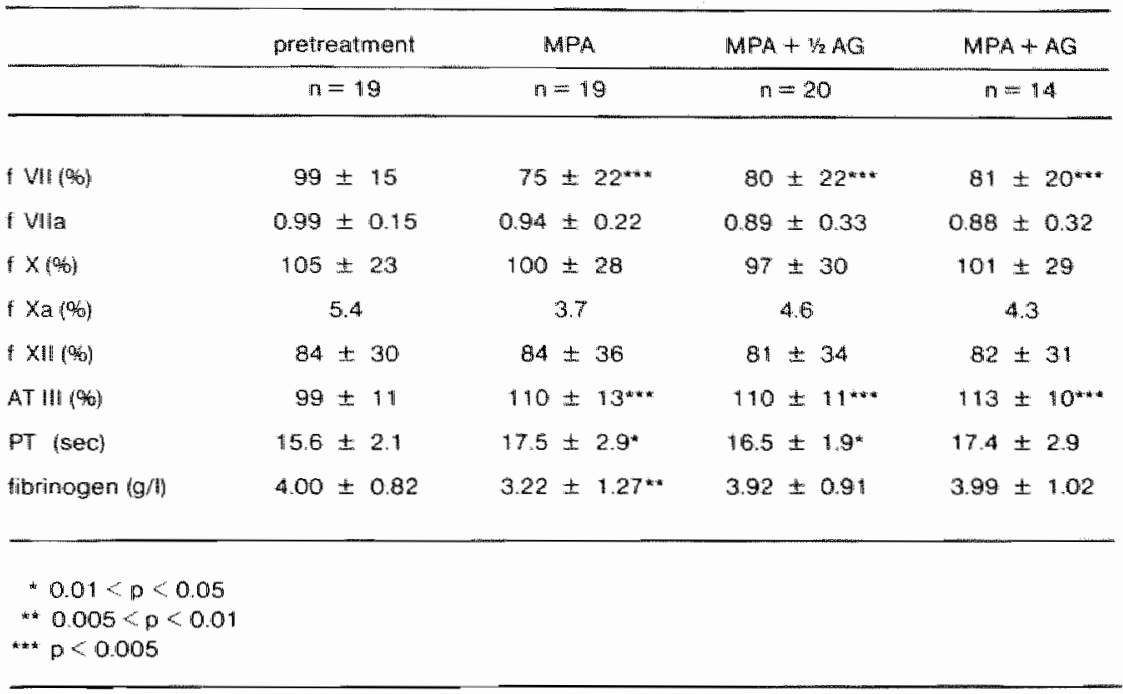

\section{Results}

1. Coagulation studies (Table I, figure 1)

1.1. Before treatment: mean plasma levels of factor VII, factor VIla factor $X$, factor XII, PT, fibrinogen an AT III were normal. In 10 out of 20 patients plasma factor Xa levels were increased. The median level is given as values of factor $\mathrm{Xa}$ are not normally distributed about the mean. Cold-promoted activation of factor VII occurred in 12 out of 19 patients.

1.2. During treatment with high-dose MPA alone: a significant decrease in factor VII and fibrinogen occurred. A prolonged PT and an increase in AT III was found. In only 5 out of 19 patients cold-promoted activation of factor VII could still be etablished $(\mathrm{p}<0.05)$. In the 5 patients who persisted to show this phenomenon mostly lower levels of cold-promoted activation of factor VII were observed. No significant change in factor $\mathrm{X}$, factor $\mathrm{Xa}$, factor $\mathrm{XII}$ and factor VIla occurred, although the median plasma factor Xa level returned to normal. 


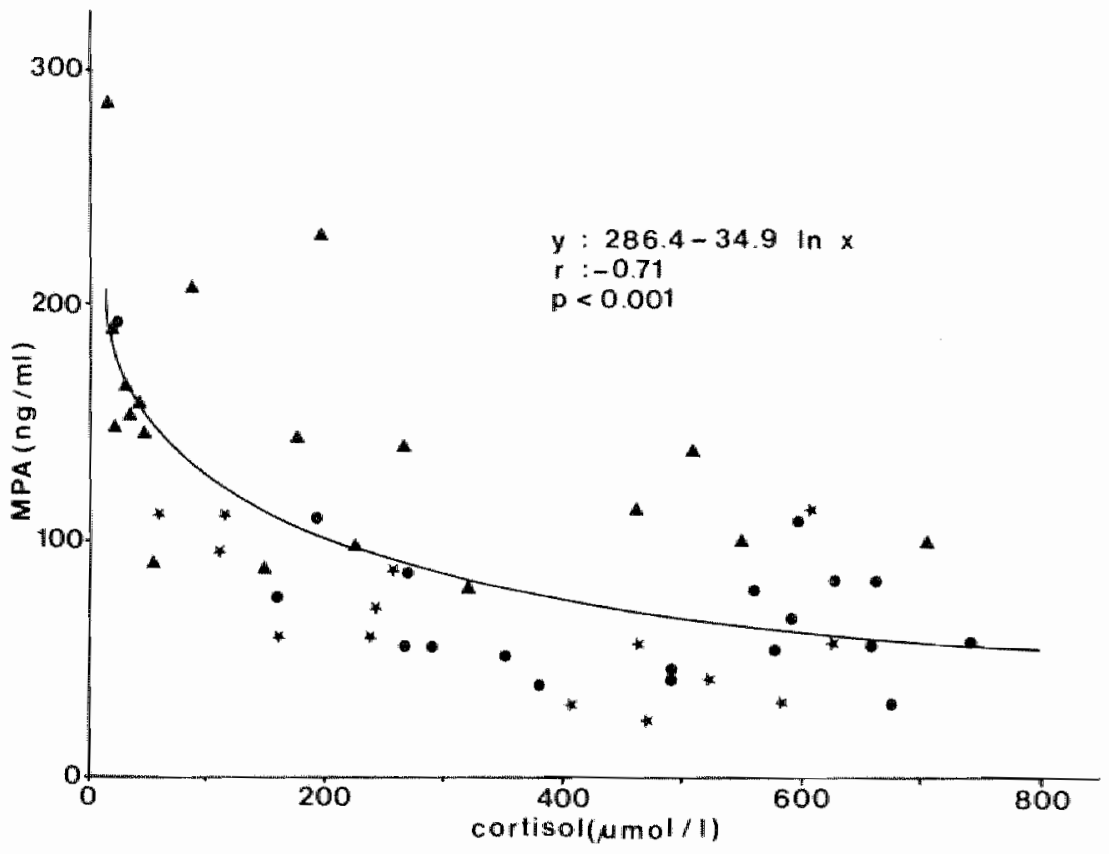

Figure 2. Correlation between serum cortisol and plasma MPA levels using a log curve tit.

$\Delta=$ MPA at a dose of $500 \mathrm{mg} 3$ times/day

- MPA at a dose of $500 \mathrm{mg} 3$ times/day + AG at a dose of $250 \mathrm{mg}$ twice/day 
1.3. During treatment with high-dose MPA plus AG: plasma fibrinogen levels returned to pretreatment values. While the changes in factor VII and AT III persisted, the prolongation of the PT was no longer significant. This loss of significance is probably due to too few observations. In relation to pretreatment levels the cold-promoted activation of factor VII remained significantly decreased. This decrease was unrelated to the response to treatment. Aglain factor VIla, factor $X$, factor $X a$ and factor XII did not change significantly.

2. Hormonal studies (Table II)

2.1. Before treatment: serum contisol was normal and serum estrogens were within the lower range of normal values for postmenopausal women.

2.2. During treatment with high-dose MPA alone: a significant decrease in serum cortisol to subnormal levels occurred. Serum estrone fell to about $65 \%$ of basal values. Serum estradiol only fell to $75 \%$ of basal values.

2.3. During treatment with high-dose MPA plus AG: plasma MPA levels fell about $50 \%$ after addition of AG to MPA showing an inverse correlation with serum cortisol, which normalized in most cases (figure 2). These extended observations confirmed the results in seven patients described in Chapter VI. Compared with pretreatment values serum estrone levels showed no further decrease, but remained significantly decreased at the same level. Serum estradiol even increased slightly and significance did not persist, probably because of too few observations.

3. Correlation patterns between coagulation and hormonal parameters Only a weak correlation could be found between plasma AT III levels and serum estrone (figure 3). No correlation between plasma AT III levels and serum estradiol was found. This might be attributed to the very low detectable levels of estradiol in postmenopausal patients in which range exact measurements are impossible. No correlation between pllasma AT III levels and serum cortisol or plasma MPA levels existed. No correlation could be found between piasma factor VII and either serum estrogens, serum cortisol, or plasma MPA levels.

The two patients suffering from thromboembollic disease had no outstanding features in their coagulation and hormonal parameters studied. 


\section{Table Il}

Results 1 SD of hormonal assays determined before and during treatment with MPA, $1500 \mathrm{mg}$ daily and after addition of $\mathrm{AG}, 500 \mathrm{mg}$ daily (1/2 $\mathrm{AG}$ ) and $1000 \mathrm{mg}$ daily (AG).

\begin{tabular}{|c|c|c|c|c|c|}
\hline & & pretroatment & $M P A$ & $M P A+1 / 2 A G$ & $M P A \pm A C$ \\
\hline & & $n=16$ & $n=19$ & $n=20$ & $n=14$ \\
\hline cortisol & (gmol/1) & $491 \pm 146$ & $202+207^{* *}$ & $446 \pm 205$ & $420 \pm 207$ \\
\hline estrone & (pmol:1) & $144 \pm 59$ & $94 \pm 30^{\text {nat* }}$ & $93 \pm 26^{* k}$ & $91 \pm 28^{* * *}$ \\
\hline estrudial & (pmolli) & $62 \pm 22$ & $46 \pm 11 \%$ & $48 \pm 11^{*}$ & $50 \pm 13$ \\
\hline MPA & $(\mathrm{mg} / \mathrm{m}$ al $)$ & $\rightarrow$ & $\| 46.4 \pm 547$ & $738+355^{4}$ & $683 \pm 323$ \\
\hline
\end{tabular}

$-0.01<0<0.05$

$* 0.005<p<0.01$

$* * 0<0.005$

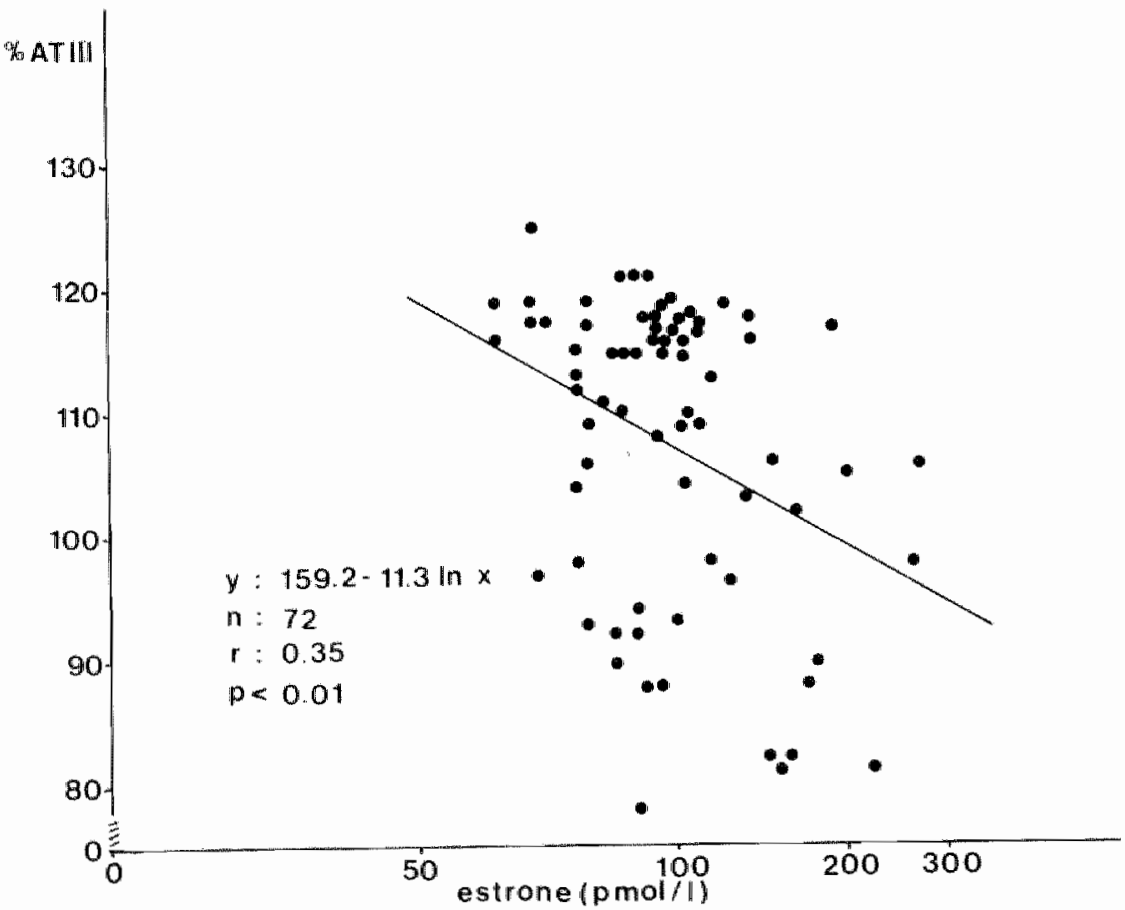

Figure 3. Correlation between serum estrone and plasma AT III levels using a log curve fit. Observations before and during treatment. 


\section{Discussion}

We studied blood coagulation enzymes and the inthibitor AT III during hormonal treatment of postmenopausal breast cancer patients. We focussed on those enzymes which may be important in the initiation of blood coagulation and in relation to cancer $(15$, Chapter I and $\mathrm{V})$. In postmenopausal patients with a various extent of advanced breast cancer pretreatment blood coagulation parameters were mostly in the normal range except for plasma factor Xa levels which were increased in 10 out of 20 patients. There was no relation between the number of sites of disease and plasma factor Xa levels. One might speculate that in the patients with increased plasma factor Xa levels tumor cells or their secreted microvesicles were circulating at the moment of blood sampling.

Cold-promoted activation of factor VII occurs in about $25 \%$ of normal women (personal observation). The observed higher incidence of cold-promoted activation of factor VII in our patients cannot easily be explained, but might point to the importance of in vivo clotting activation in this disease. There was no relation between the number of sites of disease or the plasma levels of factor VII and the occurrence of cold-promoted activation of factor VII. Plasma factor XII levels were not increased. A decrease in $C_{1}$-esterase inhibitor might be an explanation, but this is unlikely, since Chawla et al reported serum levels of $\mathrm{C}_{1}$-esterase inhibitor in a group of patients with metastatic cancer, which were significantly higher than normal (16).

During treatment with high-dose MPA alone and in combination with $A G$ the effects on blood coagulation enzymes appeared to be opposed to clot formation. A persistent decrease in plasma factor VII levels and its cold-promoted activation occurred. Also a persistent increase in plasma AT III activity was found, although within normal levels. These levels remained altered in spite of the changes in glucocorticoid activity and varying plasma progestagen levels during treatment, as expressed by serum cortisol and plasma MPA levels (see Chapter VI).

Studies concerning the effect of low and moderate high doses (i.e. not adrenal suppressive) of progestagens always revealed normal factor VII levels $(6,7,8,9,10)$. In vitro addition of purified MPA to the patients plasma did not influence pretreatment factor VII levels or cold-promoted activation of factor VII, excluding a direct effect of MPA on these parameters (personal observation). Only serum estrogens showed a persistent decrease during treatment. One might speculate whether the decreased serum estrogen levels could be responsible for the observed changes in the haemostatic parameters mentioned. Estrogen treatment is known to cause 
increased levels of factor VIl and to induce cold-promoted activation of factor VII $(17,18,19$, Chapter 11$)$. So conversely, one might hypothesize that a decrease in serum estrogen levels might lead to a decrease in factor $V I I$ and/or to changes in the proteins important in the cold-promoted activation of factor VII opposite to those induced by estrogens. However, as to factor VII levels, such a hypothesis is not in accordance with the findings of Meade et al. They observed higher plasma factor VIll levels in postmenopausal as compared with premenopausal women, although the menopausal status of their patients had been ill defined (20).

As to the increased AT III levels observed during treatment, high-dose MPA alone exerts a progestagenic and glucocorticoid effect and induces decreased estrogen levels. Although prednisone has been reported to induce an increase in AT III activity in an elderly group of patients, it cannot explain the persistent increase after addition of AG, which abolishes the glucocorticoid effect (21). During treatment with low or moderately high doses of progestagens various findings in plasma AT III levels have been reported $(6,7,22)$. During treatment with estrogens, a decrease in AT III levels has been observed, whereas in postmenopausal women higher levels of AT III have been reported as compared with premenopausal women $(23,24)$. Although a progestagenic effect cannot entirely be excluded, these findings and the weak correlation we observed between plasma AT III and serum estrone levels suggest an increase in AT III levels due to decreased serum estrogen levels induced by the treatment.

The decrease in plasma fibrinogen concentration during high-dose MPA alone is probably a consequence of the corticosteroid influence in the patient. This probably causes a lowering of acute phase reactants such as fibrinogen, as has been reported by others (21).

We conclude that during treatment with high-dose MPA alone or in combination with AG in postmenopausal women with advanced breast cancer the effects on blood coagulation enzymes are opposed to clot formation. Therefore changes in other factors of importance in the coagulation process, such as fibrinolytic or platelet activity, or the disease state itself should be considered responsible for the incidence of thromboembolic disease.

Furthermore, the changes in plasma factor VII and in its cold-promoted activity as well as in AT III activity are probably caused by the estrogen suppressive effect of the treatment. 


\section{References}

1. Teulings F.A.G., van Gilse H.A., Henkelman H.S., Portengen H., Alexieva-Figusch J. Estrogen, androgen, glucoconticoid and progesterone receptors in progestin-induced regression of human breast cancer. Cancer Res. 40:2557-2561, 1980.

2. van Deik W.A., Bliham G.H., Mellink W.A.M., Meulenberg P.M.M. Influence of aminogiutethimide on plasma levels of medroxyprogesterone acetate. its correlation with serum cortisol levels. Cancer Treat. Rep. 69: 85-90, 1985 .

3. Blossey H.C., Wander H.E., Koebberling J., Nagel G.A. Pharmacokinetics and pharmacodynamic basis for the treatment of metastatic breast cancer with high-dose medroxyprogesterone acetate Cancer 54:1208-1215, 1984 .

4. Johnson J.R., Priestman T.J., Fotherby K., Kelly K.A.,Priestman S.G. An evaluation of high-dase medroxyprogesterone acetalle (MPA) therapy in women with advanced breast cancer. Br. U. Cancer 50:363-366, 1984

5. Cavalli F., Goldhirsch A., Jungi F., Martz G., Mermillod B., Alberto P., for the Swlss Group for Clinical Cancer Research. Randomized trial of low-versus high-dose medroxyprogesterone acetate in the induction treatment of postmenopausal patients with advanced breas cancer. J. Clin. Oncol. 2: 414-419.1982.

6. Schenk H., Fereberger W. Gestagen-Therapie des Mammakarzinoms. Einfluss hoher dosen auf das Gerinnungssystem. Münch. Med. Wschr, 125: 875-876, 1983.

7. Rosso R., Boccardo F., Canobbio L., Querirolo M.A., Zarcone D., Brema F. Effect of high-dose medroxyprogesterone acetate on blood clotting factors and platelet function. In: Proceedings of the International Symposium on Medroxyprogesterone Acetate. Cavall F. MCGuire W.L., Pannuti F. et al, (eds). Excerpta Medica, Amsterdam. 151-157, 1982.

8. Poller L., Thomson J.M., Tabiowo A., Priest C.N. Progesiterone oral contraception and blood coagulation. Br. Med. d. 1: $554-556,1969$.

9. Baele G., Vermeulen A., Thiery M. Blood coagulation and platelet function parameters before and during parenteral administration of medroxyprogesterone acetate as a contraceptive agent. Thromb. Diathes. Haemorh. (Stuttg) 31. 346-353, 1974.

10 . Whigham K.A.E., Howie P.W., Mack A., Prentice C.R.H. The effect of an injectable progestagen contraceptive on blood coagulation and fibrinolysjs.

Brit. J. Obstet. Gynaec. 86: $806 \cdot 809_{n} 1979$.

11. Vermeulen A. The hormonal activity of the postmenopausal ovary. J. Clin. Endocrinol Metab 42: 247-253, 1976.

12. Santen R.J., Brodie A.M.H. Suppression of estrogen production as treatment of breast carcinoma: pharmacological and clirical studies with aromatase inhibitors.

Clin. Oncol. 1: 77-130, 1982.

13. Nagel G.A., Wander H.E., Blossey H.C. Phase Il study of aminoglutethimide and medroxyprogesterone acetate in the treatment of patients with advanced breast cancer. Cancer Res. 42: $3442-3444,1982$.

14. Veltkamp J J., Muller A.D., Loeliger E.A. Indication, kssay procedures, diaghoses and advice. In: Human Blood Coagulation. Hemker H.C. Loeliger EA., Voltkamp J.J. (eds.). Boerhaave Series, Leiden. 152-224, 1969.

15. Rickles F.R., Edwards R.L. Activation of blood coagulation in cancer: Trousseau's syndrome revisilied. Blood 62: 14-31, 1983.

16. Chawla R.N., Rausich D.J., Miller F.W., Vogler W.A.s Lawson D.H. Abnormal profile of serum proteinase inhibitors in cancer patients. Cancer Pes. 44:2718-2723, 1984.

17. Meade T.W., Haines A.P., North W.A.S., Chakrabarti R., Howarth D.J., Sti.ling Y. Haemostatic, lipid, and blood-pressure profiles of women on oral contraceptives containing $50 \mu \mathrm{g}$ or $30 \mu \mathrm{g}$ oestrogen. Lancet $i, 948 \mathrm{~m} 951,1977$. 
18. Gordon E.M., Ratnoff O.D. Jones P.K. The role of augmented Hageman factor factor $x / 1$ viters in the cold-promoted activation of factor VII and spontaneous shortening of the prothrombin time in women using oral contraceptives. J. Lab. Clin. Wed $99.363-369,1982$.

19. Wessler S., Gitel S.N., Wan L.S., Pastemack B.S. Estrogen-containing oral contraceptive agents: a basis for their thrombogenecity. J.A.M. 236: 2179-2182, 1976

20. Meacte T.W., Imeson J D., Haines A.P., Stirling Y. and Thompson S.G. Menopausal status and haemostatic wariables. Lancet i: $22-24,1983$.

21. Jumgensen $K A_{A}$., Sorensen $P$. Freund L. Effect of glucocorticosteroids on some coagulation tests. Acta Haemat. 68: $39-42,1982$.

22. Conard J.,Samama M.., Horellou M.H., Zorn J.R.., Neau C. Antothrombin lll and oral contraception with progestagen-only preparation. Lancet ii: $474,1979$.

23. Stanwell-Smith $\mathbf{R}$., Meade T.W. Hormone replacement therapy for menopausal women: a review of its effects on haemostatic function, lipids, and biood pressure. Adv. Drug React. Ac. Pois. Rev. 4: $187-210,1984$.

24. Notelovitz M., Kitchens C.S., Rappaport V., Coone L., Dougherty M. Menopausal status associated with increased inhibition of blood coagulation. Am. I. Obstet. Gynaecol. 141:149-152,1981. 


\section{Summary and Conclusions}

In Chapter I the literature concerning the relation between blood coagulation and cancer is reviewed, with emphasis on the coagulation parameters studied. The histologic evidence of fibrin formation around tumor cells is discussed as well as the clinical incidence of thromboembolic disease in cancer patients, which can manifest itself in different states of disease. The laboratory abnormalities vary widely depending on the type of cancer, the state of disease, the coagulation parameters studied and the methods used by the investigators.

Fibrinopeptide A (FPA) levels in plasma appeared to be a promising although non-specific parameter for progressive disease, however upon reevaluation the method used to determine FPA turned out to be a refined determination of both circulating and in vitro formed fibrin(ogen) degradation products. In the discussion of the pathophysiology the possible role of factor VIla and factor Xa in the relation between tumor cells (with their accompanying phagocytic cells) and activation of blood coagulation is stressed.

Finally, the role of coumarin derivatives as the most promising form of anticoagulant cancer treatment and the future possibilities for the application of fibrinolytic agents are discussed.

It can be concluded that systematic investigations regarding the activation of blood coagulation factors sofar have not been carried out and that ongoing activation of blood coagulation in vivo might be reflected in elevated levels of activated coagulation factors in circulating blood.

In Chapter II the outline of our investigations is presented and in Chapter III a coagulation assay is described that allows the measurement of the degree of activation of factor VII in circulating blood. The test is based on the use of both bovine and human brain thromboplastin, together with an artificial factor VII deficient plasma. The latter can be prepared on a relatively large scale which makes it possible to measure factor VII activation in large series of patient samples. The activity state of factor VII in plasma could best be expressed by the ratio of factor VII activity as measured with bovine versus human thromboplastin. Differences in the time course of factor VII activation during incubation in glass and plastic containers are found and implicate that rigorous standardization of blood sampling and test conditions is necessary. A possible mechanism 
that causes this critical dependence upon the test conditions is discussed. The determination of factor VII activation during incubation at $4^{\circ} \mathrm{C}$ of plasma of women using oral contraceptives shows that the test adequately measures factor VII activation.

In Chapter IV the test to determine the activity state of factor VII has been applied to study the mechanism of the cold-promoted activation of factor VII. It could be shown that the cold-promoted activation does not occur in factor II, XII and, of course, VII deficient plasmas and is reduced for about $50 \%$ in factor IX deficient plasma. The other coagulation factors have a minor influence on the process. The role of factor II has been further elucidated by testing normal pooled plasma supplemented with various amounts of the thrombin inhibitor hirudin. The cold-promoted activation of factor VII was abolished completely in plastic and only partly in glass by hirudin in a dose dependent way. The mechanism by which thrombin activates factor VII remains uncertain. There appeared to be no relation with kallikrein generation.

In Chapter $\mathbf{V}$ the results of the determinations of blood coagulation parameters in 106 patients with and without metastatic cancer of the breast, kidney and prostate are described. Coagulation factors VII, VIlla, X and Xa as well as antithrombin III were measured. Only 2 out of 45 patients with metastatic disease had increased factor Vila levels, whereas 16 out of 46 patients had increased factor Xa levels. Only in breast cancer patients factor Xa levels were significantly higher in patients with compared to without metastases. None of the coagulation parameters measured could be shown to be associated with, let alone to predict, the occurrence of clinical metastatic disease during longitudinal follow-up of patients without evidence of metastases. Only for antithrombin III levels a relation could be shown with the number of sites of disease. Finally, in those patients in whom fibrin(ogen) degradation products and alpha-2-antiplasmin were meastured hardly any abnormalities of these parameters could be shown. It was concluded that none of the blood coagulation parameters measured could be used as a tumor marker for clinical purposes, with the possible exception of factor Xa in breast cancer patients.

In Chapter $\mathrm{VI}$ the complex interaction between aminoglutethimide (AG) and medroxyprogesterone acetate (MPA) are described. These two agents are active in the endocrine treatment of metastatic breast cancer. The explanation of the effects of MPA alone, and in combination with $A G$, on progestagen and glucocorticoid levels is 
important for the understanding of the effects on blood coagulation parameters (see Chapter VII). During treatment of postmenopausal breast cancer patients we observed a $50 \%$ decrease of plasma MPA levels after addition of AG. With large interindividual differences in plasma MPA levels, a significant correlation with serum cortisol levels was found. It could be concluded that AG leads to a lowering of plasma MPA levels to such an extent that the adrenal suppressive effect of MPA may be diminished or even abrogated. The implications of these findings for the treatment of patients with the combination of AG and MPA are discussed.

Chapter VII, finally, describes the effects of treatment with highdose MPA allone and MPA in combination with AG on blood coagulation parameters. The study was done to see if changes in the blood coagulation parameters could explain the thromboembolic disease, which has been reported to occur during MPA treatment. Two of the 20 patients studied actually showed thromboembolic disease. With high-dose MPA alone a significant prolongation of the prothrombin time, and decrease of fibrinogen and factor VII was observed, while levels of plasma antithrombin III activity increased. After adding AG only the changes in factor VII and antithrombin III persisted. Hormonal studies revealed a persisting decrease in serum estrogen levels during this treatment, while plasma MPA levels and the occurrence of high-dose-MPA-related glucocorticoid activity varied. Moreover, a weak but significant correlation between plasma antithrombin III and serum estrone levels was found. We conclude that the changes in the blood coagulation parameters measured during treatment with high-dose MPA alone and in combination with AG do not favor clot formation. This means that the thromboembolic disease during treatment with high-dose MPA should rather be caused by changes in fibrinolytic or platelet activity or by the disease state itself. Changes in plasma factor VII and antithrombin III levels might be related to changes in serum estrogen levels. 



\section{Samenvatting en Conclusies}

In Hoofdstuk I wordt een overzicht gegeven van de relatie tussen bloedstolling en kanker, waarbij de nadruk wordt gelegd op de door ons bestudeerde stollingsparameters. Er wordt ingegaan op het histologische bewijs van fibrinevorming rondom tumorcellen en op de klinische verschijnselen van ontregelde haemostase bij kankerpatiënten. Deze stoornissen in de haemostase kunnen zich in uiteenlopende ziektebeelden voordoen. De afwijkingen in stollingsparameters bij laboratorium onderzoek lopen sterk uiteen, afhankelijk van het soort maligniteit, de gemeten stollingsparameters en de door de verschillende onderzoekers gebruikte methoden. Het zag er naar uit dat plasma fibrinopeptide A (FPA) een veelbelovende, zij het niet specifieke, parameter zou zijn voor het optreden van progressieve ziekte. Echter, reëvaluatie van de gebruikte methode voor de FPA bepaling liet zien dat hiermee behalve FPA zelf ook allerlei fibrin (ogeen)-afbraakprodukten werden gemeten, die het FPA bevatten. Bovendien bleek dat deze afbraakprodukten zowel in vivo als in vitro waren gevormd.

Vervolgens wordt de betekenis van de activatie van factor VIla en factor Xa in de relatie tussen stollingsactivatie en kanker toegelicht. Tenslotte wordt ingegaan op de rol van coumarine-derivaten die van alle vormen van antistollingsbehandeling de beste anti-tumor werking hebben. In dat verband komen ook de toekomstige mogelijkheden van een behandeling met fibrinolytisch werkzame geneesmiddelen aan de orde.

Hoewel bij niet-klinisch onderzoek de activatie van stollingsfactoren zoals factor VII en factor $X$ in relatie met kanker is aangetoond, is er nooit systematisch onderzoek gedaan naar geactiveerde stollingsfactoren in het bloed van kankerpatiënten. Het zou best kunnen dat voortgaande activatie van de bloedstolling bij de patiênt met kanker zich weerspiegelt in het voorkomen van verhoogde spiegels van geactiveerde stollingsfactoren in het bloed.

In Hoofdstuk II wordt kort weergegeven welk onderzoek in de afgellopen periode is verricht.

In Hoofdstuk III wordt de test beschreven waarmee factor VII activatie kan worden bepaald. De test is gebaseerd op het gebruik van bovine en humaan hersenthromboplastine, met daarnaast een artificieel vervaardigd factor VII deficiënt plasma. Dit plasma kan op grote schaal worden bereid en maakt het mogelijk om metingen in 
een groot aantal bloedmonsters te verrichten.

Hel bleek dat factor Villa het beste kon worden uitgedrukt in de ratio factor VII activiteit gemeten met bovine thromboplastine gedeeld door factor VII activiteit gemeten met humaan thromboplastine. Er bleek verschil te bestaan in het optreden van activatie van factor VII in de loop van de tijd bij incubatie van plasma in glazen of plastic buizen bij $4^{\circ} \mathrm{C}$. Dit houdt in dat het verzamelen, het verwerken en het testen van bloedmonsters volgens nauwkeurige voorschriften moet gebeuren. Op het mechanisme van het verschil in tijd tussen activatie van factor VII in glazen en plastic buizen tijdens incubatie bij $4^{\circ} \mathrm{C}$, wordt verder ingegaan.

Het feit dat factor VII activatie in het plasma van vrouwen die "de pil' gebruikten, kon worden vastgesteld, houdt in dat de door ons gebruikte bepalingsmethode adequaat factor VII activatie kan meten.

In Hoofstuk IV wordt onze methodiek om factor VIla te bepalen nader getoetst door het mechanisme van koude activatie van factor VII te bestuderen.

Koude activatie van factor VII bleek niet op te treden in factor II, factor XII en, vanzelfsprekend, factor VII deficiënt plasma.

Daarnaast was de koude activatie van factor $V I I$ in factor IX deficiënt plasma 50\% minder. De andere stollingsfactoren hadden nauwelijks invloed op het proces. De rol van factor II werd verder onderzocht door normaal 'pooled' plasma aangevuld met verschillende hoeveelheden hirudine (een thrombine-remmer) in de kou te laten incuberen en vervolgens factor VII activatie te meten. Afhankelijk van de dosis verdween onder invloed van hirudine de koude activatie van factor VII geheel bij koude incubatie in plastic en slechts gedeeltelijk in glas. De manier waarop thrombine factor VII activeert blijft onverklaard. Er blijkt geen relatie te zijn met kallikreine vorming.

In Hoofdstuk $\mathbf{V}$ worden de resultaten beschreven van de stollingsfactor-bepalingen bij 106 patiënten met en zonder gemetastaseerd mamma-, nier- en prostaatcarcinoom.

De stollingsfactoren VII, VIIa, X, Xa en antithrombine III werden bepaald. Slechts 2 van de 45 patiënten met gemetastaseerde ziekte hadden verhoogde factor VIla spiegels, terwijl 16 van de 46 patiënten een verhoogde factor Xa spiegel hadden. Slechts bi] patiënten met mammacarcinoom waren factor $X a$ spiegels. significant hoger in de groep met metastasen dan in de groep zonder metastasen. Geen van de gemeten stollingsparameters bleek tijdens de follow-up te zijn geassocieerd met het optreden van 
klinisch manifeste metastasering bij aanvankelijk niet manifest gemetastaseerde patiënten. Alleen plasma antithrombine III spiegels bleken gerelateerd te zijn aan het aantall lokalisaties van metastasen. Afwijkingen in de bepalingen van fibrin(ogeen)afbraakprodukten en alfa-2-antiplasmine konden bij onze patiënten niet worden vastgesteld. Mogelijk met uitzondering van factor Xa bij mammacarcinoom kan worden vastgesteld dat geen van de gemeten stollingsparameters klinisch toe te passen is als tumormarker.

In Hoofdstuk VI wordt de ingewikkelde interactie beschreven tussen aminoglutethimide (AG) en medroxyprogesteron acetaat (MPA). Deze twee geneesmiddelen worden toegepast bij de hormonale behandeling van gemetastaseerd mammacarcinoom. Om de effecten van deze geneesmiddelen op de stollingsparameters te kunnen begrijpen (zie Hoofdstuk VII), is het belangrijk eerst uit te leggen wat het effect van MPA alleen, en in combinatie met AG, is op spiegels van progestagene en glucocorticoide activiteit in plasma resp. serum. Tijdens de behandeling van postmenopauzale vrouwen met gemetastaseerd mammacarcinoom vonden wij een daling van de plasma MPA spiegels van $50 \%$ na de toevoeging van AG. Ondanks dezelfde MPA dosering bij de patiënten bleken er interindividueel grote verschillen in plasma MPA spiegels te bestaan, die significant gecorreleerd waren aan serum cortisol spiegels. Geconcludeerd kan worden dat toevoeging van AG aan MPA tot een zodanige daling van de plasma MPA spiegels kan leiden, dat het onderdrukkende effect van hoge dosis MPA op de bijnierschorsfunctie daardoor kan verminderen of zelfs helemaal kan verdwijnen. Op de betekenis van deze bevindingen voor de behandeling van de patiënten met de combinatie van AG met MPA wordt nader ingegaan.

In Hoofdstuk VII worden tenslotte de effecten van behandeling met hoge dosis MPA alleen en MPA in combinatie met AG op de stollingsparameters beschreven. Dit onderzoek werd verricht om te zien of er veranderingen in de stollingsparameters konden worden vastgesteld, die de thromboseneiging tijdens behandeling met MPA, zoals in de literatuur beschreven, zouden kunnen verklaren. Twee van de 20 onderzochte patiënten kregen inderdaad een thrombo-embolische ziekte. Met hoge dosis MPA alleen trad een significante verlenging van de prothrombinetijd en een daling van de plasma fibrinogeen en factor VII spiegels op, terwijl plasma antithrombine III toenam. $\mathrm{Na}$ toevoeging van $\mathrm{AG}$ persisteerden alleen de veranderingen in factor VII en antithrombine III. Gelijktijdig verrichte hormoonbepalingen lieten een persisterende daling in de serum oestrogeen spiegels zien tijdens deze behandeling, terwijl de 
plasma MPA spiegels en de aan de hoge dosis MPA gerelateerde glucocorticoide activiteit varieerden. Daarnaast werd er een geringe maar significante correlatie vastgesteld tussen de plasma antithrombine III en serum oestron spiegels. Geconcludeerd kan worden dat de veranderingen in de stollingsparameters, gemeten tijdens behandeling met hoge dosis MPA alleen, en in combinatie met $A G$, allesbehalve de bloedstolling bevorderen. Dit houdt in dat de thromboseneiging tijdens de behandeling met hoge dosis MPA eerder moet worden toegeschreven aan veranderingen in de fibrinolytische activiteit, de thrombocytenfunctie, of aan de ziekte zelf. De veranderingen in de plasma factor VII en antithrombine III spiegels zijn mogelijk gerelateerd aan de serum oestrogeen spiegels. 


\section{Appendix}

\section{Short outline of normal blood coagulation}

\section{Introduction}

Interrelated processes that cause the cessation of blood flow through the wall of a damaged vessel are called haemostasis. In relation to cancer such vascular defects can be brought about directly by migration of tumor cells through the vessel wall or when tumor cell thrombi cause ischaemic damage of the endothelial layer of the vessels distal from the site of obstruction by the thrombus. The main components participating in normal haemostasis are platelets, blood coagulation enzymes, endothelial cells that line the blood vessels and the smooth muscle cells of the vessel wall. Their relative contribution to the haemostatic process depends on the extent of the damage and its localization.

\section{The role of the smooth muscle cells}

Vascular constriction can be brought about by neurogenic vasospasm, precapillary sphincter constriction and humoral vasospastic agents, such as serotonin, kinins and thromboxane $A_{2}$. The mechanism of vasoconstriction is effective to stop a bleeding in the capillary bed. In arterioles and venules, however, the interaction of subendothelial structures with platelets and blood coagulation factors is more important.

The role of platelets

When exposed to subendothelial structures platelets rapidly adhere to these structures. A subsequent release of platelet contents such as $A D P$, serotonin and thromboxane $A_{2}$ into the micro-environment leads to aggregation of new platelets and vasoconstriction. Upon activation the platelet becomes procoagulant: a number of coagulation factors (as well as protease inhibitors) are released, while changes in the plasma membrane result in the formation of a surface on which fibrin formation can proceed with increased velocity. This close cooperation between platelets and clotting factors results in the production of a fibrin reinforced platelet plug localized at the site of the vascular defect.

The role of coagulation factors

Although the surface of activated platelets triggers fibrin formation, it is not the first trigger for activation of the coagulation cascade, 
however. When tissue factor is exposed in the damaged area complex formation with coagulation factor VIl takes place in the presence of ionized calcium $\left(\mathrm{Ca}^{++}\right)$. This first step in the extrinsic pathway of blood coaglulation is followed by activation of factor $X$. Traces of activated factor $X$ activate factor $V I I$ into its two chain form which makes further activation of factor $X$ proceed with increasing velocity (a so called 'reinforcement loop').

The intrinsic pathway is initiated when in the damage area exposure of subendothelial structures result in an activation process in which factor XII, prekallikrein, high molecular weight kininogen and factor $X \mid$ are involved. Locally activated factor $X \mid$ activates factor $\mid X$ and factor IXa activates factor $X$. This latter process takes place on a phospholipid surface and is accellerated by factor VIlla. The extrinsic and intrinsic pathways come together in the factor $X$ activation step.

Factor $X a$ then generates thrombin from factor II. Thrombin generation again takes place on a phospholipid surface and the velocity of enzyme activation is increased by the presence of factor Va. The ultimate visible effect of coagulation is the conversion of soluble fibrinogen into insoluble fibrin by thrombin.

Moreover, thrombin also activates platelets, factor $V$ and $V I I I$ and factor XIII, a glutaminase that stabilizes the polymeric fibrin meshwork

Physiologically the extrinsic and intrinsic pathway are not as separated as was previously assumed. The activation of factor IX by the tissue factor factor VII complex has been firmly established.

The relative importance of activation of factor $I X$ by the tissue factorfactor VII complex compared to activation of factor IX by factor XIa is still unclear.

Other links between the extrinsic and intrinsic pathways are activation of factor VII by alpha-factor XIIa or beta-factor XIIIa. This is probably not of physiological importance, but it mediates the cold-induced factor VII activation during incubation at $4^{\circ} \mathrm{C}$.

Furthermore, factor VII can be activated by factor IXa, but much less effective than by factor Xa.

The coagulation process is autocatalytic and self-limiting. Thrombin also activates protein $\mathrm{C}$, a vitamin $\mathrm{K}$-dependent protease that inactivates factors Va and VIIla. Inhibitors of the proteolytic clotting enzymes are present in the whole vascular system and so active coagulation enzymes can only exist at the site of injury where their formation proceeds much faster than their inactivation. 
Tissue repair and fibrinolysis

Finally, as soon as the bleeding has stopped, the tissue repair process starts. The fibrin meshwork with red cells and thrombocytes is removed by fibrinolytic and phagocytic processes. At the same time healthy adjacent cells divide to close the damaged site. The fibrinolytic system is activated by tissue-type plasininogen activator relleased from the endothelium. This proteolytic enzyme activates plasminogen, the zymogen of the fibrinolytic enzyme plasmin. Plasminogen activation takes place in the fibrin mesthwork, thereby confining the fibrinolytic process to the site of injury. The fibrinolytic enzymes that enter the circulation after resolution of the fibrin meshwork are rapidly inactivated by the fibrinolytic inhibitors present in the blood, of which alpha-2-antiplasmin is the most important one.

For more detailed information the reader is referred to recent reviews $(1,2,3)$.

1. van Dam-Mieras M.C.E., Muller A.D. Blood coagulation as a part of the haemostatic system. In: Blood coagulation - New Comprehensive Biochemistry, vol 13. Zwaal R.F.A., Hemker H.C. (eds.). Elsevier Science Publishers, Amsterdam, Chapter 1, 1986.

2. Lämmle B., Griffin J.H. Formation of the fibrin clot: the balance of procoagulant and inhibitory factors. Clin Haematol. 14: 281-343, 1985.

3. Osterud B. Activation pathways of the coagulation system in normal haemostasis. Scand. J. Haematol. 32: 337-345, 1984. 


\section{Dankwoord}

Om te beginnen wil ik de vele patienten danken, die het mij mogelijk hebben gemaakt hel onderzoek te verrichten. Hierbij betrek ik ook de vele medewerkers in het ziekenhuis die vrijwillig bloed afstonden. Coen Hemker stelde mij in staat het grootste deel van dit proefschrift in het biochemisch laboratorium te bewerken. Hem dank ik voor de steun in de afgelopen jaren.

Mijn co promoter Rietje van Dam was mijn voortdurende inhoudelijke en psychologische steunpilaar. Zonder jou, Rietje, was dit boekje niet tot stand gekomen.

Mijn co-promotor Geert Blijham dank ik voor zijn inspirerende ideeën betreffende het klinisch deel van thet onderzoek. Zijn kritische beoordeling van de tekst leidde tot verbetering en verheldering.

Puck Muller dank ik voor haar aandeel in de laboratorium proeven, voor de fijne samenwerking, haar voortdurend optimisme over de goede afloop, en het verzorgen van de tekeningen van alle figuren. Paul Devilée dank ik voor het leveren van de vele benodigde reagentia. Van hem en Puck heb ik leren stollen.

De referenten Guus Flendrig, Gouke Kootstra en Prof. Dr. M.B. Donati dank ik voor hun kritische beoordeling van het manuscript. Mieke Haemers dank ik voor haar grote inzet, nauwkeurigheid en uithoudingsvermogen, waarmee zij het manuscript heeft getypt en keer op keer de correcties heeft ingevoerd.

Bernice Doove, Marie-Cécile Jacobs en Gerard Bos waren mij in hun jaar ais student-assistent tot grote steun.

Bert Bas was bereid vele vrije uren met ons stollingstesten te doen. Annemiek Mellink, de verpleegkundigen van het Dagcentrum en de polikliniek-assistentes dank ik voor hun medewerking bij het verzamelen van bloedmonsters en het agenderen van vervolgafspraken.

Dr. M. Ausems en Dr. D. Mendes de Leon, die mij in staat stelden voldoende patiënten voor deze studie te kunnen vervolgen, dank ik voor hun medewerking.

Lex Volovics en Michel Janssen hielpen mij bij de statistische verwerking van de gegevens.

Ine Ridder en Jan Jonker zorgden voor de lay-out en het drukken van dit boekje.

'Last but not least" dank ik Emmie en de jongens. Emmie, jouw steun en aanmoediging zijn al die jaren een grote stimulans voor mij

118 geweest. Wij hebben veel, aan dit boekje verloren, tijd in te halen. 


\section{Curriculum vitae}

De schrijver van dit proefschrift werd geboren op 11 december 1947 te 's-Gravenhage. Hij behaalde het Gymnasium $\beta$ diploma in 1966 aan het Christelijk Lyceum Delft, te Rijswijk $(\mathrm{ZH})$.

In hetzelfde jaar begon hij de studie geneeskunde aan de Rijksuniversiteit te Leiden. Het artsexamen behaalde hij in maart 1974.

Hij begon zijn opleiding tot internist op 1 december 1974, op de afdeling Interne Geneeskunde van het Gemeenteziekenhuis Leyenburg te 's-Gravenhage (opleider Dr. P.S. Blom). Voorafgaand had hij 9 maanden gewerkt op de afdeling intensive care van genoemd ziekenhuis (Dr. B. van Dijk). Tijdens de opleiding volgde hij stages in de cardiologie (Dr. C.M. Sparling), gastroenterologie (Dr. P. van Leeuwen) en haematologie (Dr. C.H.W. Leeksma). Sinds september 1979 is hij werkzaam bij de Rijksuniversiteit Limburg, verbonden als internist aan de afdeling Interne Geneeskunde (Prof. Dr. J.A. Flendrig) binnen de groep haematologie-oncologie (Dr. G.H. Blijham) van het Ziekenhuis St. Annadal, per 1 januari 1986 Academisch Ziekenhuis Maastricht. 


\section{Colophon}

Design: Ine Ridder

Drawing of the figures: Puck Muller

Printed by Cartoprint BV, Den Haag

Printing of this thesis was partly supported by a grant of ICl Holland B.V.

$120 \quad$ ISBN $909001326 \quad 1$ 